\title{
Contested Discourses of Sustainability in Old Ottawa South
}

\author{
by
}

\author{
Donald Leffers
}

A thesis submitted to the Faculty of Graduate Studies and Research in partial fulfillment of the requirements for the degree of

\author{
Master of Arts \\ in \\ Carleton University \\ Ottawa, Ontario \\ (C) 2010, Donald Leffers
}

Geography and Environmental Studies 
Library and Archives Canada

Published Heritage Branch

395 Wellington Street Ottawa ON K1A ON4 Canada
Bibliotheque et

Archives Canada

Direction du

Patrimoine de l'édition

395 , rue Wellington

Ottawa ON K1A 0N4

Canada
Your file Votre référence ISBN: 978-0-494-81608-0

Our file Notre référence

ISBN: 978-0-494-81608-0
NOTICE:

The author has granted a nonexclusive license allowing Library and Archives Canada to reproduce, publish, archive, preserve, conserve, communicate to the public by telecommunication or on the Internet, loan, distribute and sell theses worldwide, for commercial or noncommercial purposes, in microform, paper, electronic and/or any other formats.

The author retains copyright ownership and moral rights in this thesis. Neither the thesis nor substantial extracts from it may be printed or otherwise reproduced without the author's permission.
AVIS:

L'auteur a accordé une licence non exclusive permettant à la Bibliothèque et Archives Canada de reproduire, publier, archiver, sauvegarder, conserver, transmettre au public par télécommunication ou par l'Internet, prêter, distribuer et vendre des thèses partout dans le monde, à des fins commerciales ou autres, sur support microforme, papier, électronique etou autres formats.

L'auteur conserve la propriété du droit d'auteur et des droits moraux qui protège cette thèse. $\mathrm{Ni}$ la thèse ni des extraits substantiels de celle-ci ne doivent être imprimés ou autrement reproduits sans son autorisation.
In compliance with the Canadian Privacy Act some supporting forms may have been removed from this thesis.

While these forms may be included in the document page count, their removal does not represent any loss of content from the thesis.
Conformément à la loi canadienne sur la protection de la vie privée, quelques formulaires secondaires ont été enlevés de cette thèse.

Bien que ces formulaires aient inclus dans la pagination, il n'y aura aucun contenu manquant. 


\begin{abstract}
Urban sustainability, though widespread within the popular and academic discourse, is seldom scrutinized critically. This thesis, theoretically informed by poststructural political ecology and methodologically framed by Foucaultian discourse analysis, interrogates how particular knowledges of sustainability are produced and contested through the circulation of power. Using case study research in Ottawa, Canada, this thesis shows how social actors and institutions discursively produce urban sustainability. This research addresses questions around what counts as nature, how nature is socially 'produced', and what practices become normalized within hegemonic constructions of urban sustainability. As this thesis shows, current urban planning in Ottawa privileges growth and legitimizes the sustainable development discourse by commodifying nature essentializing growth within a 'development apparatus' that seeks to sustain a commodified nature to serve the global economy. Many research participants contest hegemonic discourses of sustainability, instead privileging consultative policies and practices that support quality of life, community identity, and heritage preservation.
\end{abstract}




\section{Acknowledgements}

Many people assisted me in the development of this thesis; to all of you I am truly grateful. Thank you to Patricia Ballamingie, my thesis supervisor, whose guidance, advice, and hard work made for a valuable and enjoyable research and writing process. Thank you to Jill Wigle, for your advice and expertise, especially in the realm of urban planning and governance, and for guiding me towards interesting and useful reading material. Thanks to all my colleagues in the MA room, for sharing your thoughts and creating a congenial atmosphere. To Fiona Mackenzie and David Bennett, thank you for challenging me to think in new ways and for all your support and guidance throughout the course of my MA. Thank you to the Department of Geography and Environmental Studies, and particularly to Natalie Pressburger, for always being there when I had questions and concerns (and for always having the answers). I would also like to thank all the research participants in Old Ottawa South. Your generosity with your time and candidness with your insights helped make this a valuable research experience. Thanks to Neil for listening and sharing your time. To Deidre, thank you for your patience, support, and excellent editing skills. Frederick, thank you for your unique insights and fantastic space ships. Vera, thank you for showing me clearly how power operates. 


\section{Table of Contents}

Chapter 1: Introduction ......................................................................................1

1.1 Urban Sustainability in North America ........................................................ 3

1.2 Towards Sustainability in the Canadian City............................................. 4

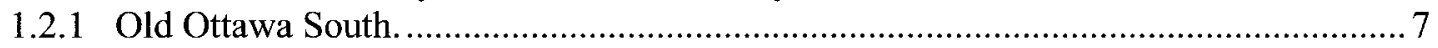

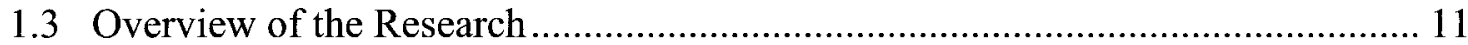

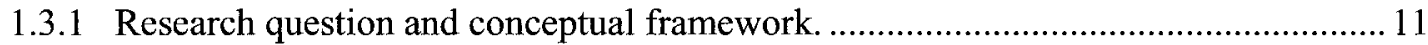

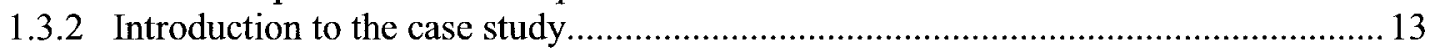

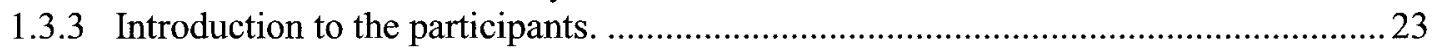

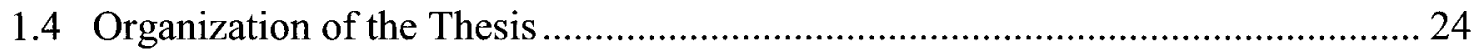

Chapter 2: Conceptual Framework ...............................................................25

2.1 A Critical Approach to Sustainability ........................................................... 26

2.2 Poststructural Discourse Theory and Sustainability ...................................... 28

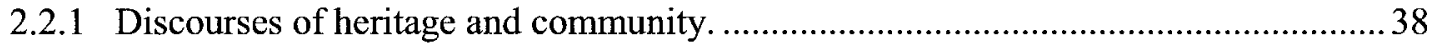

2.3 Political Ecology and the Social Construction of Nature ..................................40

2.3.1 Contributions from poststructuralist theory. .................................................. 42

Chapter 3: Methodological Framework.............................................................46

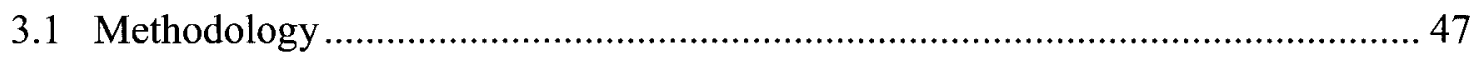

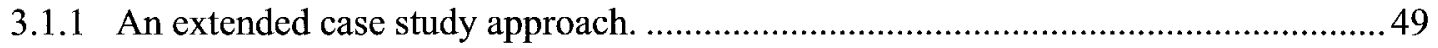

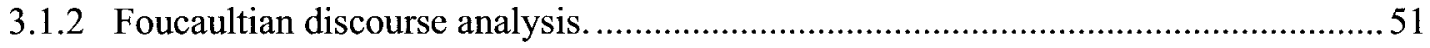

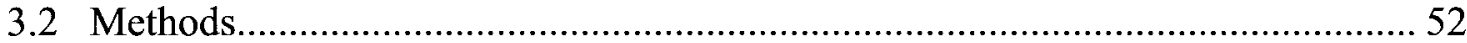

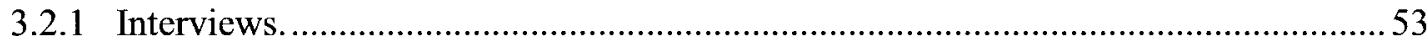

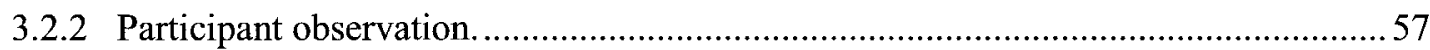

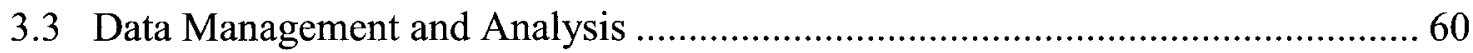

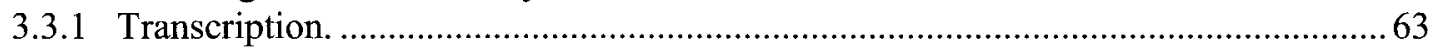

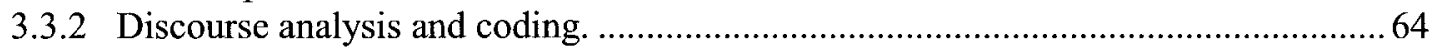

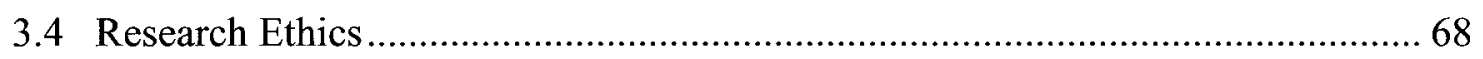


Chapter 4: The Social Construction of Sustainability in Ottawa....................70

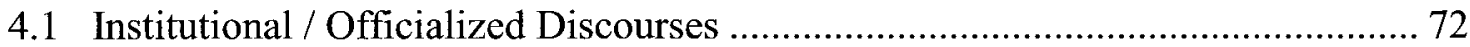

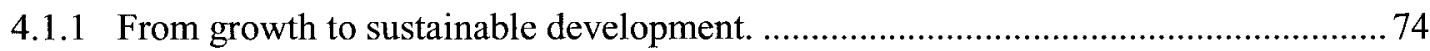

4.1.2 Scalar discourses of sustainable development............................................... 77

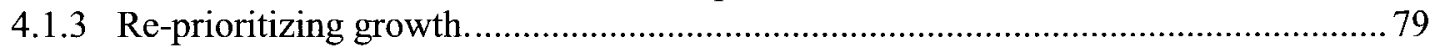

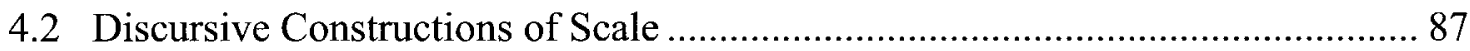

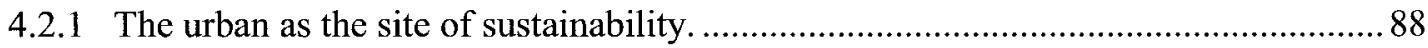

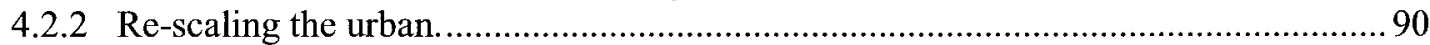

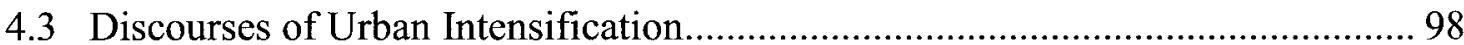

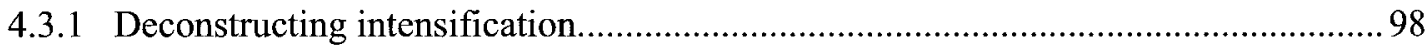

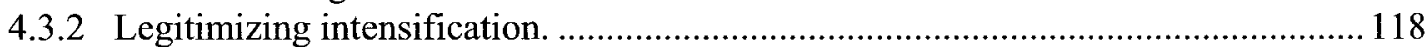

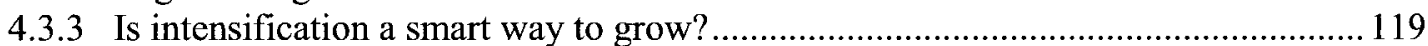

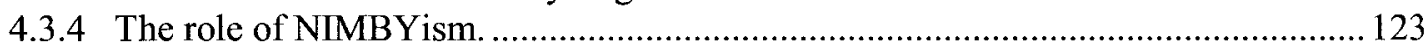

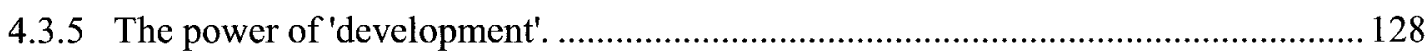

4.3.6 Exercising 'infrapower': Resisting the 'development apparatus'............................. 131

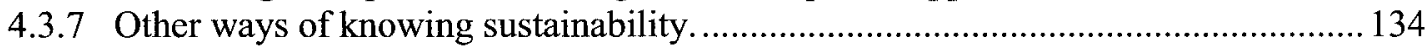

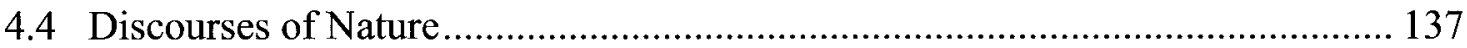

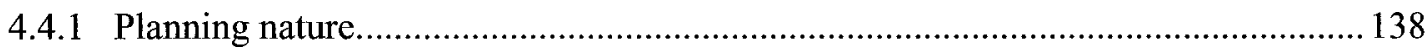

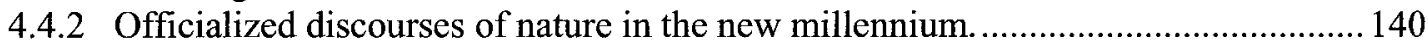

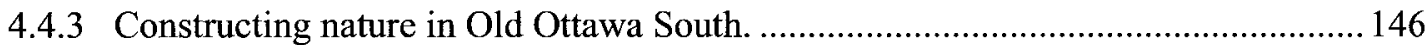

4.5 The Social Construction of Sustainability in Ottawa: Conclusions.................... 152

Chapter 5: Discourses of Community in Old Ottawa South ........................154

5.1 Creating Community ................................................................................... 155

5.2 Discursive Constructions of Community .................................................. 164

5.2.1 Performativity: The process of becoming community subjects. ............................. 165

5.2.2 Becoming an activist in Old Ottawa South..................................................... 167

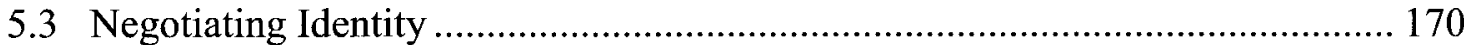

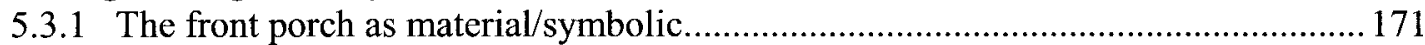

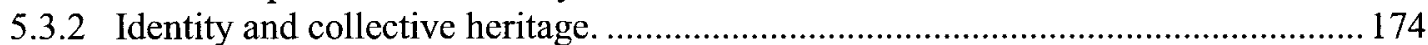

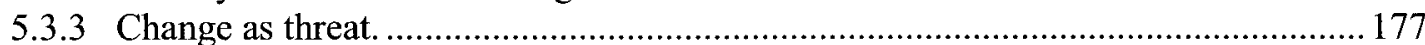

5.3.4 Beyond representation: The politics of community associations.......................... 180

5.4 Sustainability as Threat.......................................................................... 188

5.4.1 Urban development as a capitalist enterprise.................................................. 189

5.4 .2 Private property rights and individualism. ........................................................ 191

5.5 Towards an Identity of Possibility and Hope: Conclusions............................ 193 
Chapter 6: Conclusion ........................................................................................197

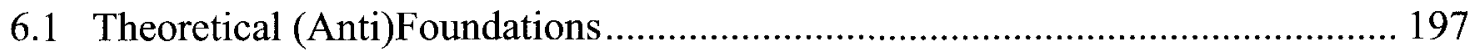

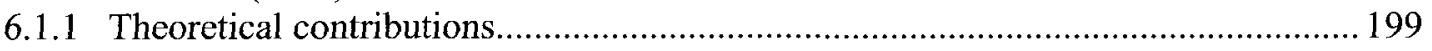

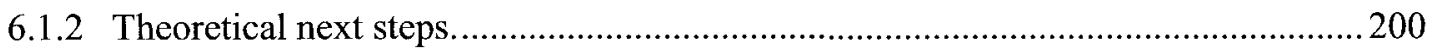

6.2 Sustainability, Community, and Heritage in Old Ottawa South...................... 200

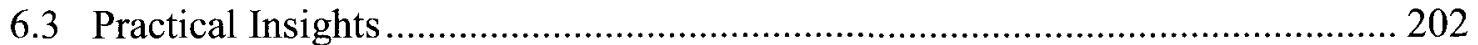

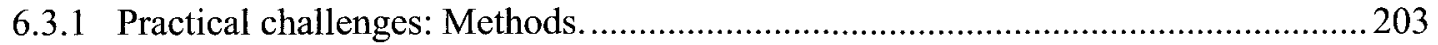

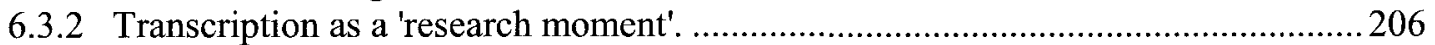

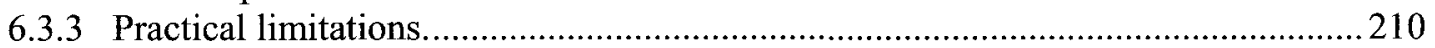

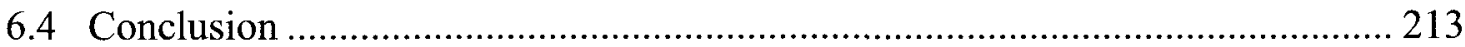

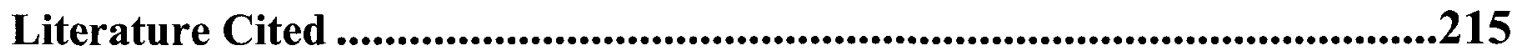

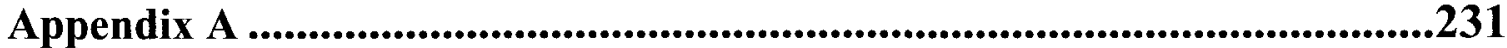

Appendix B ........................................................................................................2232

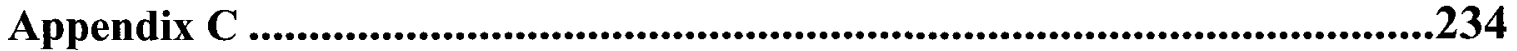




\section{List of Figures and Tables}

Figure 1.1: $\quad$ Location map of Old Ottawa South $\quad 8$

Figure 1.2: Redevelopment of 88 Bellwood 15

Figure 1.3: $\quad$ Proposed Shoppers Drug Mart at Bank and Sunnyside 19

Figure 1.4: Redevelopment of 35 Brighton 22

Figure 4.1: Locations and boundaries of the City of Ottawa's 23 wards 91 relative to the greenbelt

Figure 4.2: Campanale Homes' website advertisement of 35 and $\quad 113$ 37 Brighton Avenue

Figure 4.3: Ottawa's growth management strategy 141

Figure 4.4: Planning hierarchy in the City of Ottawa 142

Table 4.1: City of Ottawa urban, suburban, and rural wards and 92 their councillors in 2009 


\section{List of Appendices}

Appendix A: The 10 principles of Smart Growth 231

Appendix B: Discursive constructions of Barrhaven as the antithesis of 232 sustainability

Appendix C: Guiding principles of the 1991 City of Ottawa Official Plan 234 


\section{List of Key Abbreviations and Acronyms}

$\begin{array}{ll}\text { CDP } & \text { Community design plan } \\ \text { FCA } & \text { Federation of Citizens' Associations of Ottawa-Carleton } \\ \text { MMAH } & \text { Ministry of Municipal Affairs and Housing } \\ \text { NIMBY } & \text { Not in my backyard } \\ \text { OMB } & \text { Ontario Municipal Board } \\ \text { OSHP } & \text { Ottawa South History Project } \\ \text { OSCA } & \text { Ottawa South Community Association } \\ \text { Oscar } & \text { Ottawa South Community Association Review } \\ \text { OSWatch } & \text { Ottawa South Watch: zoning and development subcommittee of OSCA } \\ \text { RMOC } & \text { Regional Municipality of Ottawa-Carleton } \\ \text { TOD } & \text { Transit oriented development }\end{array}$




\section{Chapter 1: Introduction}

The concept of sustainability can be traced at least as far back as the United Nations Conference on the Human Environment of 1972 (UNEP, 1972) and subsequently, to the widely cited United Nations' publication Our Common Future: Towards Sustainable Development (often referred to as The Brundtland Report; WCED, 1987). Our Common Future outlines the three pillars of sustainability (environmental, economic, and social) and more recently, several authors have proposed a fourth pillar: cultural (EACCC, 2006; UNEP, 2002). More recent global initiatives around sustainability include the United Nations programme and publication Agenda 21; Chapter 28 of this publication calls on local authorities to adopt their own 'Local Agenda 21' in order to address sustainability through localized initiatives (UNCED, 1993).

Interest in urban sustainability in its contemporary form, is at its most general motivated by a recognition that cities, especially post World War Il North American cities, represent inherently unsustainable patterns of development and land use, characterized by sprawling suburbs and heavy reliance on the automobile (Bruegmann, 2005; Kunstler, 1993). Bruegmann (2005) notes that the term 'sprawl' is value laden: "like 'conspicuous consumption' or 'elitism', [sprawl] has always conveyed a not-so-subtle accusation against the way other people choose to live their lives" (p. 18). Bruegmann also notes that sprawl as a concept has shifted in meaning historically, but for the purposes of contemporary discourse it generally refers to an urban form characterized by low-density scattered developments that lack larger scale regional land-use planning. In 
the case of Ottawa, as Chapter 4 of this thesis highlights, the issue of sprawl is made more complex by the presence of a greenbelt, planned suburban nodes stemming from the development of this greenbelt in the 1950s and 1960s, and the more recent move towards suburban nodes as part of the transit oriented development (TOD) planning model, which the City of Ottawa is attempting to adopt to some extent (Ottawa, 2007e).

According to Wheeler (2003), the pattern of urban sprawl that typifies large North American cities "consumes large amounts of open space and agricultural land, damages natural ecosystems, requires high levels of automobile use, spatially segregates class and racial groups, and undermines place-oriented community" (p. 317). Furthermore, over half of the world's population now lives in cities and this number is projected to increase to 60 percent by the year 2030 (UN-Habitat, 2008). In light of the scalar adoption and implementation of sustainable development into both the public and academic discourse, as well as an increasing dissatisfaction with a sprawling urban form (see for example, Bruegmann, 2005; Kunstler, 1993), the concept of urban sustainability has purportedly become a priority in many municipal official plans over the last several years.

This chapter outlines the interplay between sustainable development and municipal and provincial policy, using a case study in Ottawa, Ontario. Section 1.1 introduces the implications of sustainability for urban planning - particularly as a reaction to post World War II suburban planning - and explores how individuals and collectives of individuals react to sustainability initiatives that influence development within their communities. Section 1.2 focuses the discussion on the Canadian city and introduces the study site in Ottawa: Old Ottawa South. Section 1.3 outlines the research 
objectives and the theoretical and methodological approaches to the research. Section 1.3 also specifically introduces the contested developments within the case study as well as the research participants. Finally, Section 1.4 details the organization of this thesis.

\subsection{Urban Sustainability in North America}

Urban planning movements have attempted to address the sprawling pattern of contemporary urban development, often reverting to 'neotraditional' forms (usually associated with the architecture and planning movement called 'New Urbanism') that are more compact, walkable, and mixed in terms of zoning and land-use (Calthorpe, 1993; CNU, 2001; Jacobs, 1961; Katz, 1994; SGCN, 2007). Planning initiatives drawing on the planning framework 'Smart Growth' also advocate such principles as diverse housing opportunities, alternative transportation options, protection and promotion of community identities, and protection of 'natural' areas (SGCN, 2007; see Appendix A for the 10 principles of Smart Growth). However, any policy initiatives that seek to incorporate these principles into practice inevitably result in certain unintended and unforeseen consequences. Furthermore, as sustainability initiatives traverse the scalar hierarchy from the global to the local scale, where sustainability initiatives are often practically implemented (Robinson, 2009), the effectiveness of these initiatives is often diminished or undermined by conflicting priorities (Zeemering, 2009).

Central themes within this thesis include the ways in which municipal governments construct meaning(s) of sustainability and the practical consequences of implementing particular sustainability initiatives. This thesis focuses in particular on the neighbourhood and municipal scales, where individuals, collectives of individuals, and 
'communities' contest and negotiate with higher-level governments in an attempt to influence policies and practical implications of sustainability initiatives. The notion of community will itself be problematized as a concept with multiple meanings that defies simple categorization and definition. In developing this focus into a research question, a brief overview of sustainability in the context of the Canadian city should help to establish why this research is important and what its broader significance may be.

\subsection{Towards Sustainability in the Canadian City}

Although sustainability initiatives amongst Canadian cities differ greatly, they all inevitably affect the citizens of the communities upon which they are imposed. Many cities, particularly those characterized by sprawling suburbs, have identified this sprawling built form and reliance on the automobile as important barriers to urban sustainability. As such, many municipalities, often within governmental (particularly provincial) frameworks of hierarchical authority, have attempted to refocus development within existing urban boundaries by increasing (usually population) densities, often achieved via home conversions, infill development, and redevelopment of 'underused' or abandoned space (Campsie, 1995). ${ }^{1} \quad$ This densification process, commonly referred to as

\footnotetext{
${ }^{1}$ Infill development refers to new construction inserted into empty or underused space (such as residential backyards) within an existing neighbourhood or serviced area (Campsie, 1995). For the purposes of this thesis, I have restricted the definition of redevelopment to the demolition of existing buildings and structures, and the construction of new buildings or structures in their place. Redevelopment sometimes involves 'land assembly', where a number of adjacent lots are cleared, and new (usually larger) buildings are constructed within this multi-lot footprint. The lines between infill and redevelopment become blurred when small houses on large lots are demolished and the lots are filled with buildings that maximize the allowable build-able area. In these cases there is infilling and redevelopment occurring simultaneously. Campsie (1995) includes refurbishment as a form of redevelopment but it will be excluded here, as the varying degrees of refurbishment would make the term 'redevelopment' applicable to most properties in older neighbourhoods. Adaptive reuse is also excluded from this definition, and refers to the use of a structure for purposes other than originally intended (ibid.).
} 
'intensification' stresses increased densities of buildings and populations, but can also refer to increased economic activity in a given area (Bunce, 2004; Campsie, 1995). Thus, intensification is generally perceived as a mechanism through which cities can use resources - especially land - and infrastructure more efficiently; but intensification is also a means through which municipalities can receive increased taxation from property owners, with or without these resource efficiencies (Campsie, 1995). A particularly contentious manifestation of urban intensification is the 'monster' infill: a form of infill (and/or redevelopment) that maximizes the build-able area in accordance with what the zoning allows, resulting in larger building footprints (and usually corresponding ecological footprints) than what previously occupied the space ('monster' infills will be discussed in Section 1.3 of this chapter and in Chapter 4).

In Ontario cities, such as Ottawa, intensification has become an important practical manifestation of urban sustainability as directed by official plan policies governing land-use and zoning; planners and policy makers perceive intensification as an appropriate way to curb urban sprawl, preserve 'natural' resources, such as agricultural land, and to moderate infrastructure costs (Ottawa, 2007b). Gunder (2006) cautions that intensification initiatives can expose the "pernicious nature of sustainability" (p. 213), where intensification (and the corresponding reduction in ecological footprint) is often motivated by urban sustainability goals, but can result in "a reconfiguration of settlement that may have little regard to the cost induced on those who currently or will live in these environments" (ibid.). These 'costs' are central to this thesis, as are the means through which communities react to the unintentional consequences of urban intensification. 
Many Canadian cities purportedly prioritize sustainability by adopting principles - not all of which focus on urban intensification - that are to be implemented within residential communities (Calgary, 2007; Montreal, 2005; Ottawa, 2008a; Toronto, 2007; Vancouver, 2008). Vancouver's local governance structure is unique in Canada (Sancton, 2005) and the voices of community groups have considerable influence on development practices such that sustainability programs, including initiatives around intensification, have arguably been carried out with relative success (Brunet-Jailly, 2008). Furthermore, Vancouver's 'sustainability charter' is remarkably holistic and emphasizes socio-economic issues, education, and community-based consultation (Vancouver, 2008). Other Canadian cities, such as Toronto, have seen significant conflict between developers and community groups over large redevelopment or infill projects within older, wellestablished neighbourhoods, resulting in rapid and dramatic changes in the structure of these neighbourhoods (Filion, McSpurreno, \& Appleby, 2006).

The City of Ottawa has arguably engaged with notions of sustainability (though not always framed as such) for much of its history, largely influenced by broader movements such as late nineteenth-century conservation and urban forestry initiatives (Dean, 2005), the Garden City movement - specifically the use of satellite developments and a greenbelt (Gréber, 1950) - and programs associated with the promotion of Ottawa as Canada's capital, specifically under the leadership of then Prime Minister Mackenzie King (Gréber, 1950; Taylor, 1986). In its relatively recent urban planning history - as manifested in official plans and zoning bylaws, and influenced by the Province of Ontario through the Provincial Policy Statement, the Municipal Act, the Planning Act, and the 
Ontario Municipal Board (OMB) - the City of Ottawa has made attempts at 'natural resource' conservation, including planning objectives that purportedly have some regard for what would become the three pillars of sustainability (Ontario, 1989; RMOC, 1988). ${ }^{2}$ However, it is not until 1991 that Ottawa's official plan explicitly cites sustainable urban development as its guiding principle (Ottawa, 1991a).

Ottawa's focus on urban intensification is relatively new (Ottawa, 2008a) although its origins can be found in concerns around efficiencies in land use in the 1980s and 1990s (Ottawa, 1991a; RMOC, 1988). Intensification is explicitly linked to sustainable development in the 1991 official plan: "[m]ore physically concentrated communities are essential to the achievement of Sustainable Urban Development" (Ottawa, 1991a, p. 2.3), although policies and zoning bylaws meant to achieve this increased density were not adopted until the late 1990s and 2000s (Ottawa, 2003a; 2007b; 2008a). Enabled and legitimated by policies of urban intensification, development projects in neighbourhoods such as Old Ottawa South are on the rise and community groups are increasingly contesting them based on their perception that these developments are threatening to communities (Cook, 2008, June 23; Ottawa, 2008b; Kealey, 2005).

\subsubsection{Old Ottawa South.}

Old Ottawa South (Figure 1.1) is currently recognized by the City of Ottawa as an important site for urban intensification, particularly as Ottawa's intensification efforts focus specifically on central urban areas (Ottawa, 2008a). In the early 1900s, Old Ottawa

\footnotetext{
${ }^{2}$ Although provincial governance is somewhat beyond the scope of this thesis, the provincial 'influences' here mentioned are discussed further in Chapter 4.
} 


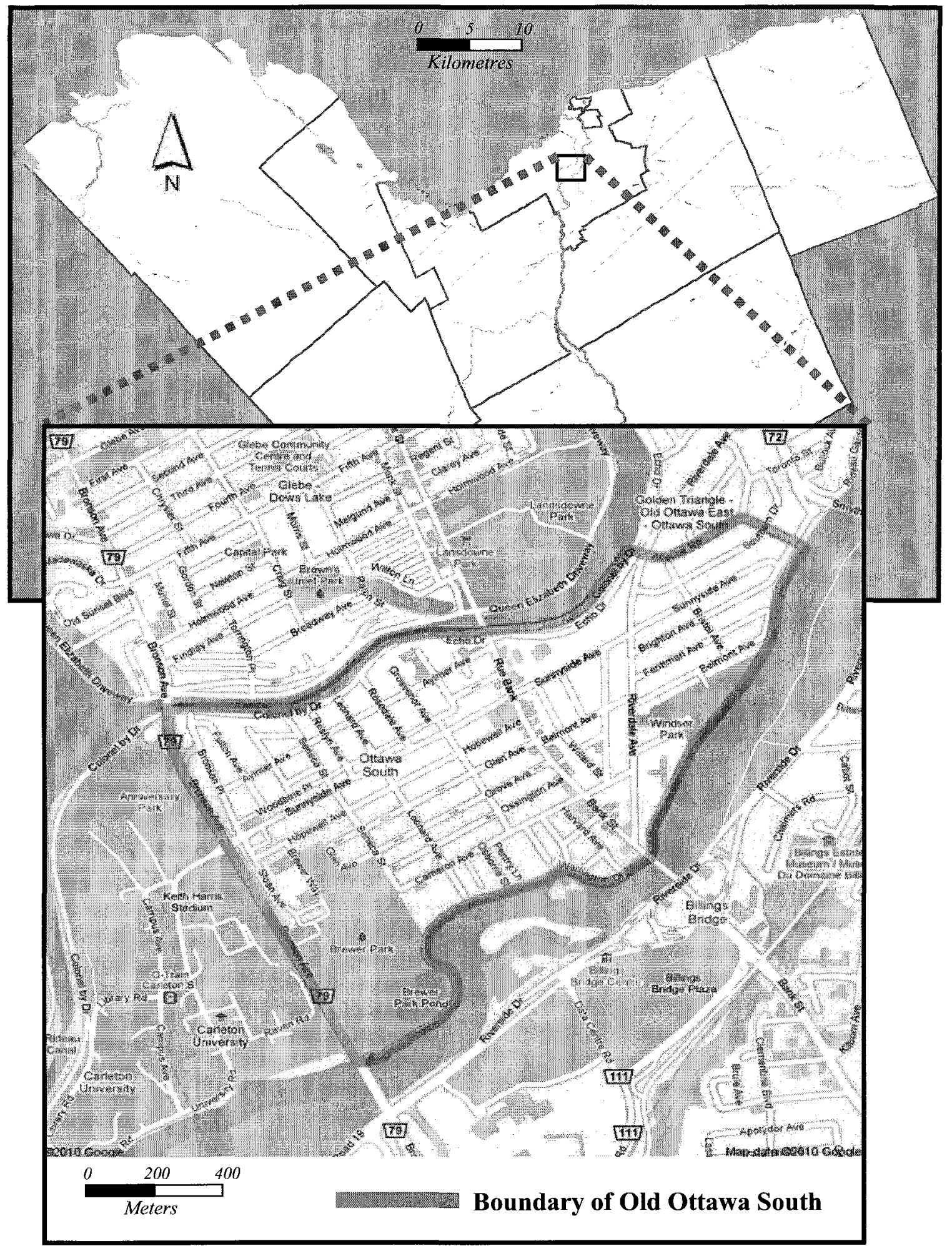

Figure 1.1. Old Ottawa South study area (inset; source: Google Maps, 2010) within the City of Ottawa (source: adapted from Ottawa, 2010a). 
South (then simply Ottawa South) was a new suburb of Ottawa and became more accessible to downtown Ottawa after a high-level bridge with streetcar tracks was built across the Rideau Canal in 1913 (Minton, 1972, August 5). The majority of houses date from between the 1920s and the 1940s and many are two or three storey detached houses (Statistics Canada, 2007). Over 60 percent of homes are detached, but a wider variety of housing types can also be found, including semi-detached houses, small (4 storeys or less) apartment buildings, cooperative housing units, townhouses, and condominiums (ibid.). Although Old Ottawa South began as a suburb (through annexation, by the City of Ottawa, of Rideauville and Wyoming Park in 1907; Minton, 1972, August 5), the City of Ottawa now frames it as both a 'traditional mainstreet' community ${ }^{3}$ and a low-medium density community ${ }^{4}$ in the central urban area, and has created design guidelines for purposes of infill and redevelopment in both types of communities (Ottawa, 2005b; Ottawa, 2006a). Within the context of redevelopment infill, Old Ottawa South has become a target for intensification; as such, the City of Ottawa has amended zoning bylaws to permit increased densities in Old Ottawa South, both along Bank Street (a traditional mainstreet), as well as within the broader community (Ottawa, 2008c).

Old Ottawa South is often referred to as 'middle class', especially within real estate advertisements (e.g., OttawaLiving.ca, 2009). If 'class' refers to such measures as income and dwelling type, then it can be described statistically. Statistics Canada's latest

\footnotetext{
${ }^{3}$ According to Ottawa (2006a) a main street is 'traditional' if the community through which it runs was developed primarily prior to 1945 . These streets tend to have small scale mixed use buildings set close to the street, resulting in "a lively mix of uses and a pedestrian-friendly environment" (ibid., p. 1). ${ }^{4}$ Although Ottawa (2005c) does not specify precisely what constitutes a low-medium density community, or a site for low-medium density infill, it alludes to 'well-established' neighbourhoods that have some opportunity for infill development.
} 
census data was published in 2007 and is based primarily on data collected in 2006

(Statistics Canada, 2007). According to this data, Old Ottawa South, comprising census tracts 5050016.00 and 5050017.00 , had a population of 8168 in 2006 , nearly unchanged from $2001 .^{5}$ Standard of living is a relative measure; in general, based on income, the greater Ottawa-Gatineau area has a higher standard of living than the Province of Ontario. As such, Old Ottawa South residents have much higher incomes - over 70 percent higher - than the provincial average, but less than 50 percent higher than the greater Ottawa-Gatineau area. Other notable census data include age, household size, and population density. Old Ottawa South has a slightly higher median age than Ontario or the Ottawa-Gatineau region and about the same household size as both, at approximately 3 persons per household. The population density is approximately 40 persons per hectare (compared to less than 20 for Ottawa-Gatineau) and the residential density is approximately 16.75 residential units per gross hectare (compared to less than 2 for Ottawa-Gatineau). ${ }^{6}$ Also relevant to discussions around urban sustainability are available modes of transit to and from work. For this purpose, Old Ottawa South

\footnotetext{
${ }^{5}$ There is a disconnect between what Statistics Canada uses for census tracts and what OSCA and the City of Ottawa recognize as the boundaries of Old Ottawa South (and as shown in Figure 1.1). According to Statistics Canada (2007), the boundaries of Old Ottawa South coincide with two census tracts, 5050016.00 and 5050017.00. However, OSCA and the City of Ottawa deem only about half of 5050016.00 to be in Old Ottawa South; the other half is in Old Ottawa East (Ottawa, 1978; Ottawa, 1991b). If only half of census tract 5050016.00 is used, Old Ottawa South had a population of about 6200 in 2006.

${ }^{6}$ In various publications, the City of Ottawa measures residential density in units per net hectare. Net hectares represents 'developed' land, as opposed to land that is considered 'vacant'. Developed land is generally associated with economic or recreational activity (see Ottawa, 2006c, p. 2, for a list of activities that are considered 'development'). The use of net hectares makes comparisons between Statistics Canada (2007) density data and City of Ottawa density data problematic, as Statistics Canada uses gross rather than net land area, and its density numbers are generally much smaller than those produced by the City of Ottawa. For example, according to Statistics Canada (2007), the population density of Ottawa-Gatineau in 2006 was slightly under 20 persons per hectare. According to Ottawa (2006c), the population density for Ottawa (Gatineau was not included) in 2005 was over 76 persons per net hectare.
} 
residents generally use private vehicles less and pedestrian modes (walking or cycling) more than the provincial and Ottawa-Gatineau averages, although public transit ridership is nearly equal to the provincial average and less than Ottawa-Gatineau. Trip distances to and from place of work are not recorded by Statistics Canada.

Due to its inclusion within the central urban area and its recent history of contested intensification projects, Old Ottawa South is a suitable area in which to research the processes of municipally imposed sustainability initiatives. Furthermore, my embeddedness within this community (I currently live in Old Ottawa South) and my awareness of who many of the local actors are and what they claim to represent make Old Ottawa South a suitable research area for my thesis.

\subsection{Overview of the Research}

This thesis provides insights into the (often) competing perspectives of various stakeholders (municipal decision-makers, developers, community groups, individuals) as the City of Ottawa attempts to achieve greater urban sustainability. This section outlines the research objective and the contested developments within the case study.

\subsubsection{Research question and conceptual framework.}

The primary research objective is to evaluate the ways in which the City of Ottawa's sustainable development initiatives are contested by social actors who have their own visions of sustainability, variably privileging environmental, economic, social, and/or cultural aspects. To tackle this question, the following issues also need to be addressed: 
- What discourses does the City of Ottawa employ as it develops its sustainability initiatives, with a focus on urban intensification? What does the City mean by ‘intensification' (Ottawa, 2008a)?

- How do these initiatives reflect (or fail to reflect) the values of the communities upon which they are imposed? Who is marginalized or excluded from these initiatives?

- How is the value of built heritage accounted for by decision-makers when demolition and redevelopment are being considered?

- What discourses and practices do individuals (as community members) and community associations mobilize in order to influence municipal policies around sustainability and the practical manifestations of these policies?

This thesis addresses these questions using a conceptual framework informed by poststructural political ecology and Foucaultian discourse analysis. ${ }^{7}$ Political ecology is a field of research that interrogates the complex interrelationships between society and the environment (Watts, 2000). Poststructural theorizing questions epistemological notions of how knowledge is produced, disturbing understandings - particularly of nature - that an a priori knowledge exists, positing rather that all knowledges and meanings are socially produced (Braun \& Wainwright, 2001; Castree, 2001; Escobar, 1996; Peet \& Watts, 1996). Foucaultian conceptions of how power is exercised (e.g., Foucault, 1982/1994c) are important to this production of knowledge and these understandings will

\footnotetext{
${ }^{7}$ At its broadest, discourse analysis refers to a qualitative organization and analysis of texts for the purpose of interrogating their meaning (Tonkiss, 1998). While recognizing that many types of discourse analyses exist, specifically in the fields of linguistics and psychology (ibid.), for the purpose of this thesis the term discourse analysis refers to the specific approach developed by Michel Foucault, generally referred to as Foucaultian discourse analysis.
} 
be discussed throughout this thesis. Foucaultian discourse analysis, as an analytical method, focuses on how knowledge is produced and normalized, particularly through the analysis of texts, as well as the analysis of practices that are constitutive of specific knowledges and operations of power (Foucault, 1969/1972; Rose, 2001; Tonkiss, 1998).

The broad goal of this thesis is to use theoretical and methodological frameworks informed by political ecology and poststructuralism to interrogate discursive constructions of sustainability (as well as closely related discourses of community and heritage), such that both community actors and municipal politicians can begin to recognize the complexity of sustainability policies and practices, and to question unproblematized and naturalized discourses of sustainability that are currently in operation in many Canadian cities. I want to make explicit not only the idea that there are multiple meanings of sustainability, but that sustainability is nothing in and of itself; it is a contingent concept that has numerous possibilities (Gibson-Graham, 2003). Central to this thesis are questions around how sustainability is currently constructed and what its alternative possibilities might be, particularly vis-à-vis the exercise of power, claims to truth, and the production and normalization of particular knowledges.

\subsubsection{Introduction to the case study.}

As originally conceived, this research sought to focus on the following recent contested development projects in Old Ottawa South: redevelopment of Saint Margaret Mary Catholic Elementary School (88 Bellwood Avenue or simply '88 Bellwood') into 
townhouses; construction of a Shoppers Drug Mart on the 'brownfield' ${ }^{8}$ site at Bank Street and Sunnyside Avenue; and the residential redevelopment of 35 Brighton Avenue. However, as the research progressed, these contested development projects became reduced in focus as a starting point and topic of interview discussions, due largely to the passage of time since these developments and the culmination of other experiences (sometimes including more recent contested developments) that shaped interviewee opinions and priorities. As such, interview questions did not begin with these contested development projects, but rather, general questions were put forward based on themes that emerged from an analysis of the contested developments. Interestingly, respondents often used the contested developments to highlight their points. The contested nature of these development projects is here elaborated briefly.

\section{Redevelopment of 88 Bellwood.}

The redevelopment of 88 Bellwood (see Figure 1.2) was perhaps the most important contested project for the purpose of this research. It occurred over a lengthy period of time, mobilized a large segment of the Old Ottawa South population, and for many Old Ottawa South residents, continues to epitomize the experience of contesting and losing a redevelopment battle (as Chapters 4 and 5 highlight). The Roman Catholic Diocese established a parish in Ottawa South in 1929 (Ottawa Evening Citizen, 1929, November 12). In 1930, the Catholic School Board (then called the Separate School Board)

\footnotetext{
${ }^{8}$ The City of Ottawa defines brownfields as "abandoned, vacant, or underutilized commercial and industrial properties where past actions have resulted in actual or perceived environmental contamination and/or derelict or deteriorated buildings" (Ottawa 2007a, p. 3).
} 


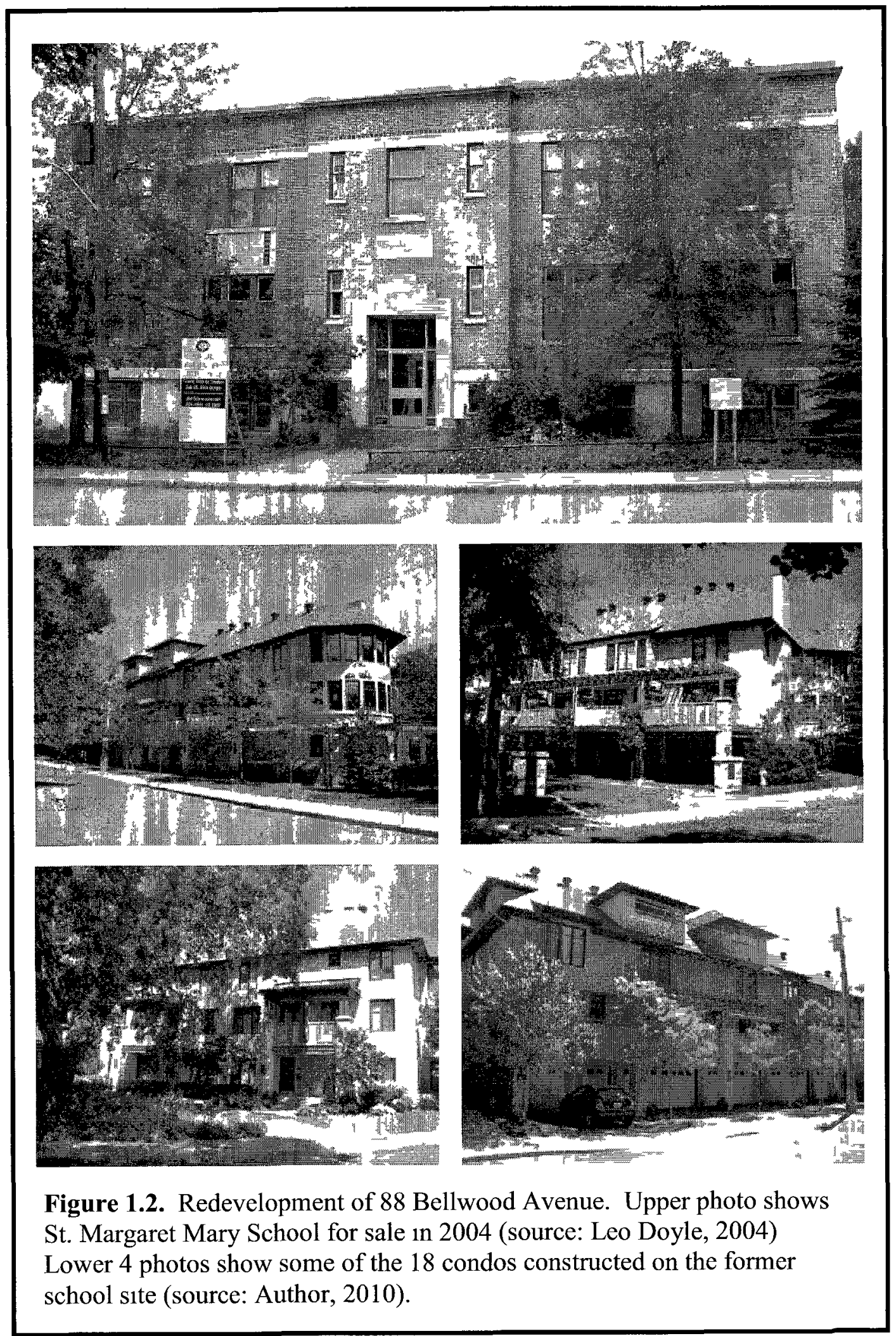


purchased the 88 Bellwood Avenue site for $\$ 3000^{9}$ and began construction of St.

Margaret Mary School (Ottawa Evening Citizen, 1930, December 4), the total cost of which was approximately $\$ 28,600$ (Ottawa Evening Citizen, Sept 23, 1930). St.

Margaret Mary Catholic School was a relatively small elementary school with twelve classrooms; it also housed the Bytown Cooperative Daycare from 1980 to 2002 (Ottawa, 2002). The Catholic School Board had threatened to close St. Margaret Mary's at least as early as 1982 (Hanna, 1982, August 23; Jensen, 1982, October 23) but the elementary school and daycare continued to operate until 2002.

In April 2002, the Catholic School Board declared St. Margaret Mary's 'surplus' and closed it; the school board sold it to a developer in November 2004, after more than two years of debate and proposals for alternative community uses of the space (Ottawa, 2005 c). Construction of new townhouses began in the fall of 2005; the townhouses were completed and fully occupied by 2006 . Although this redevelopment project proved highly controversial within the community, it was approved by the City of Ottawa in keeping with its focus on intensification:

... it is the Department's position that rezoning the subject land for residential development will advance the intent of the residential intensification policies in the new Official Plan by providing a residential infill development at a suitable urban location where services already exist. The proposal reflects a compact and balanced development providing a mix of housing types that incorporate ground-oriented housing forms and a building design that is sensitive to and compatible with the residential character of the surrounding neighbourhood. (Ottawa, 2005c, p. 3)

\footnotetext{
${ }^{9}$ Some Oscar authors suggested that the Separate School Board raised this money within the community, i.e., that the community itself actually paid for the site (Currie, 2004; Fraser, 2004; Kealey, 2004) - an assertion I have neither been able to confirmed nor refute.
} 
As is discussed in Chapter 2, residential intensification and Smart Growth principles are relatively compliant concepts: they can be manipulated and co-opted to legitimate a range of developments, including luxury townhouses. ${ }^{10}$ The City of Ottawa's Planning and Environment Committee referenced the official plan during the approved rezoning: "lands [with] this designation are intended to develop with a full range and choice of housing types to meet the needs of all ages, incomes and life circumstances ... [t]his designation facilitates the development of complete and sustainable communities" (Ottawa, 2005c, p. 3). Clearly, all redevelopments are not intended to achieve all of these lofty goals. However, the degree to which any of these goals were achieved and how they relate to discourses of sustainability will be explored throughout this thesis.

The contested development of 88 Bellwood mobilized many opponents of the project, who drew strategically upon discourses of sustainability, community, and heritage to strengthen their own positions in order to save the school and the public space. Two events associated with this development sparked controversy: the timing of demolition (curiously, it occurred the day after a meeting at City Hall discussing its very future, during which there was no mention of the scheduled demolition; Fraser, 2005); and the rezoning of the property from institutional to residential. This rezoning was seen as a loss of a community asset as it was effectively transferred to the private sector (Kealey, 2005). Many residents deemed the school to be such a vital part of the

\footnotetext{
${ }^{10}$ These townhouses, dubbed 'The Moorcroft' by Charlesfort Developments, were advertised as 'luxury townhouses in Old Ottawa South'; they ranged in size from 1725 to 2767 square feet and in price from $\$ 560,000$ to $\$ 870,000$ (The Oscar, 2005). In 2009 , one unit was listed for $\$ 995,000$ and at the time was the second most expensive home being offered in Old Ottawa South (OREB, 2009).
} 
community's history that they filed a heritage application, which was under review when the demolition took place (Fraser, 2005).

A less vocal group of individuals within Old Ottawa South supported the redevelopment project; this group mobilized competing discourses of sustainability in an attempt to influence the decision making process around rezoning and site plan control. These discourses referenced the degradation of the school building, the potential decline of neighbouring property values, and the notion of contributing to community 'progress' via the addition of newly built and compact residences (Ottawa, 2005c).

\section{Shoppers Drug Mart development.}

Shoppers Drug Mart is in the process of building a two-storey retail and office building on the site of a parking lot on the corner of Bank Street and Sunnyside Avenue. The parking lot - considered a brownfield site - hosted a variety of gas stations from the 1950 s to 2001 and a consultant found hydrocarbon-contaminated soil in several locations within the site (Pinchin Environmental, 2007). Contractors removed this contaminated soil in the fall of 2009 (Figure 1.3) and the site is now considered 'remediated' (Ottawa, 2007a). In addition to site remediation, this redevelopment also included the demolition of two turn-of-the-century two-storey houses (completed in the summer of 2009) on an adjacent lot, in order to create parking spaces (Pinchin Environmental, 2007).

This development sparked controversy in Old Ottawa South for a number of reasons. One of the initial concerns raised by local residents is that it required variances to newly approved zoning - zoning that had been developed via a consultative process with City of Ottawa planning staff and residents of Old Ottawa South (Ottawa, 2003). 


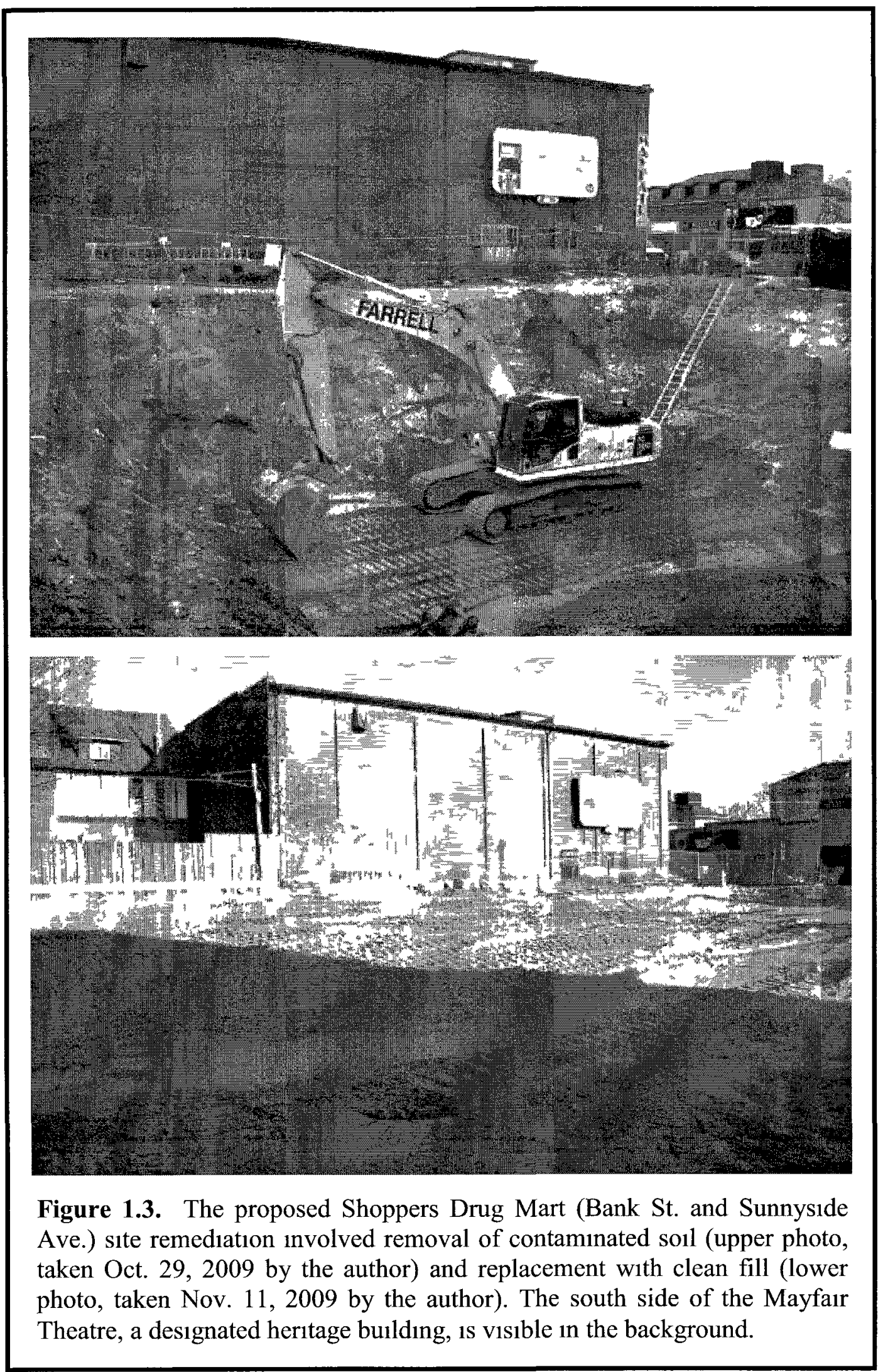


Other residents argued that the development failed to fully utilize the space: it did not include underground parking and did not take advantage of the six-storey zoning allowance (Tansey, 2008). Some residents were concerned that the development would increase traffic congestion and impair safety, especially of school children, whose school is directly adjacent to the site (Cairns, 2008; Grant, 2009; Hunter, 2008). Finally, Shoppers Drug Mart is a large chain; many local businesses and residents cited expectations that small businesses along Bank Street would be impacted negatively by the presence of this larger format 'big-box', 'category killer' type of business (Cairns, 2008; Harper, 2008; Hunter, 2008; Tansey, 2008). However, other residents, community association members, and city councillors supported the development, invoking competing discourses that include this type of business in the model of Smart Growth, by portraying Shoppers Drug Mart as providing a service to the community by rehabilitating contaminated land, and by viewing zoning and development policies as negotiations rather than fixed constraints within which developers must operate (Doucet, 2008b; Harper, 2008; Ottawa, 2008b). These discourses are discussed in Chapters 4 and 5.

\section{Redevelopment of 35 Brighton Avenue.}

Redevelopment of 35 Brighton involved the replacement of a single bungalow with two larger semi-detached homes. The bungalow was demolished in late October 2008 (Cook, 2008, June 23). Construction of the new development was started shortly thereafter and was ready for sale by the summer of 2009 (Campanale, 2009). The original bungalow was a three-bedroom home with an attached garage that had been converted to living space (MPAC, 2008). There was no parking space and the entire front yard was garden 
and lawn (Figure 1.4). Total developed living space was 1058 square feet ( $\sim 98$ square meters; ibid.). The two replacement homes are 3,376 square feet ( $\sim 314$ square meters) each and have three bedrooms (Campanale, 2008). What was front garden is now parking pad and front walk made of asphalt and interlocking paving stones; a small area in front of each entry door has been planted with trees (see Figure 1.4).

A neighbour of 35 Brighton responded immediately to this development, by organizing a petition that opposed certain aspects of the development (Ostling, 2008a). She also made a presentation to the Ottawa South Community Association (OSCA) and organized a meeting with the developer in which the petition organizers were able to facilitate a number of changes to the design of the new building (OSCA, 2008; Ostling, 2008b). The petition organizers were primarily concerned with design elements, the size of the proposed development, and the loss of green space (Ostling, 2008a). Although the petition resulted in a number of minor aesthetic changes to the proposed building ${ }^{11}$, the development received wider attention when a reporter from the Ottawa Citizen wrote a series of articles addressing the broader issues surrounding this type of development (Cook, 2008, June 23; 2008, October 27; 2009, September 23). Within these articles the policy of urban intensification is examined and the author raises some of the questions that this thesis addresses. Examples include the following: What is meant by intensification when it is applied to a development like 35 Brighton? How is this concept related to sustainability and what official plan policies enable this type of development?

\footnotetext{
${ }^{11}$ Neighbourhood intervention of 35 Brighton arguably backfired. Aesthetic changes included substituting a slightly sloped roof with two pitched sections (one for each unit), and enclosure of the second-storey balconies (see Figure 1.4). These changes resulted in the building being higher, larger, and more expensive than what was originally proposed (Cook, 2008, October 27).
} 

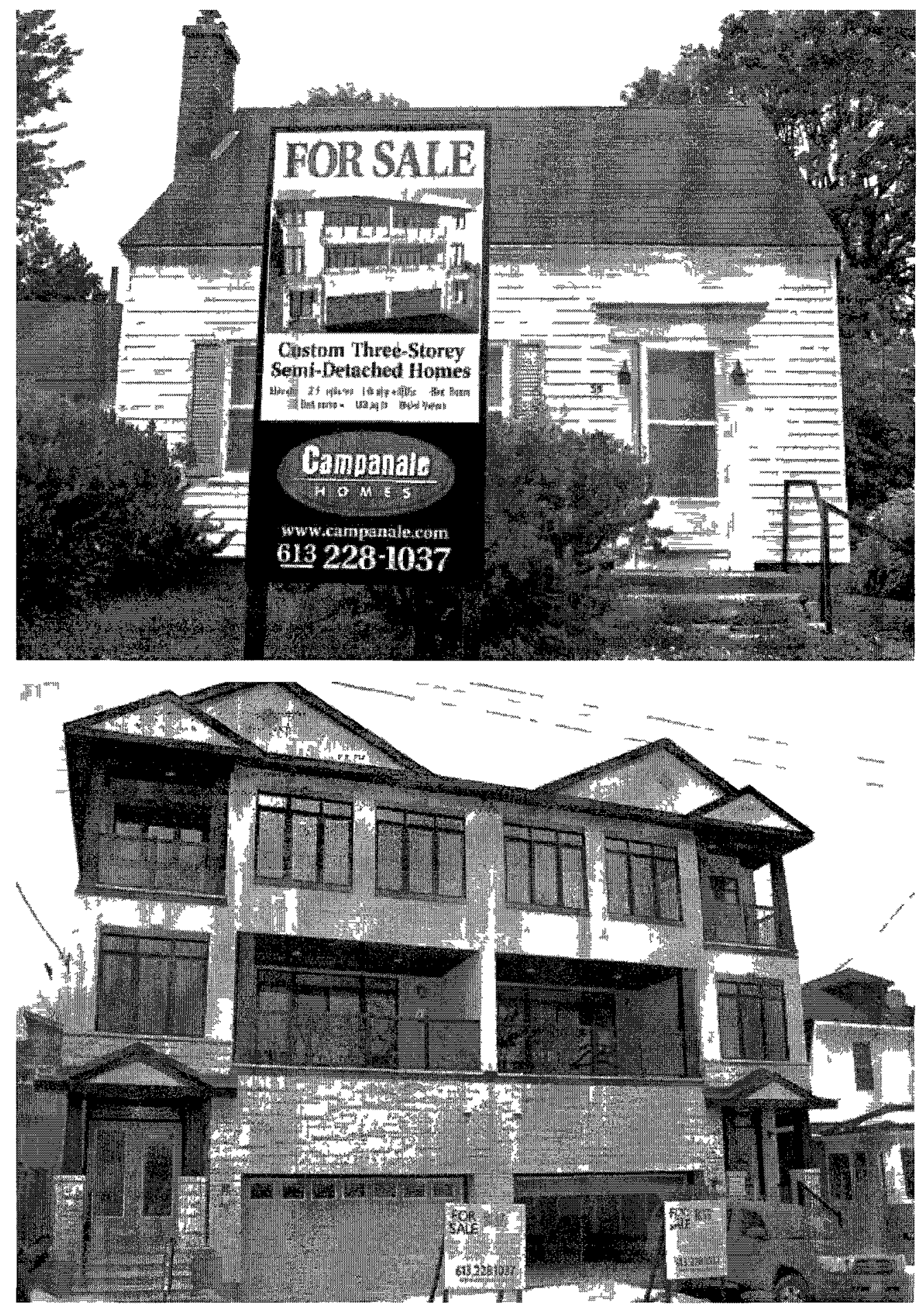

Figure 1.4. Redevelopment at 35 Brighton Avenue included the demolition of a small bungalow (upper photo; source· Cook, 2009, September 23), and the construction of 2 semi-detached homes with garages and parking in front (lower photo; source: Author, 2010). 


\subsubsection{Introduction to the participants.}

This research used in-depth, semi-structured interviews, participant observation, and archival research. As Chapter 3 elaborates, I selected interview participants purposefully, based mainly on their involvement with the 3 contested development projects, as well as their (often overlapping) affiliation with the Ottawa South Community Association (OSCA), the Ottawa South History Project (OSHP), the business community, and municipal government. Due to 'cross-membership' and for the sake of ensuring anonymity, it is difficult to explicitly and exclusively categorize participants based on these divisions. I selected at least 3 participants based mainly on affiliations with local businesses in or near Old Ottawa South. I interviewed 2 participants from Ottawa City Council: Alex Cullen and Clive Doucet. The remaining 10 participants are or have been involved with OSCA, OSHP, and/or the 3 contested development projects. Councillors Cullen and Doucet allowed me to attribute their responses; as such, for interview transcripts I simply refer to them by name and for quoted material from other sources I use conventional citation format. I use pseudonyms to refer to the remaining 13 participants. ${ }^{12}$ Participant observation produced a wide range of useful material but I refer to those involved in OSWatch and other 'sites' of participant observation in general terms only, not by name, unless data generated was public record (e.g., City of Ottawa Planning Primer led by planners Bruce Finlay and Carol Ruddy).

\footnotetext{
${ }^{12}$ I selected pseudonyms using an online random name generator based on United States Censuses (http://www.kleimo.com/random/name.cfm).
} 


\subsection{Organization of the Thesis}

The remainder of the thesis is divided up into five chapters. Chapter 2 introduces the theoretical underpinnings of this thesis, informed broadly by poststructural political ecology and drawing specifically on a body of research that interrogates critically the discursive and practical implications of urban sustainability initiatives. Chapter 3 outlines the methodological framework: one that is situated within a growing literature on poststructural political ecology and informed by and designed around Foucaultian discourse analysis (Foucault, 1969/1972). Chapter 3 also outlines the methods employed in this research - in-depth, semi-structured interviews, participant observation, and archival research - and the rationale for choosing this specific suite of methods. It also discusses methods of analysis, with a brief description of transcription and coding, and a more in-depth discussion on discourse analysis. Chapter 4 comprises the main body of analysis, drawing on the research to produce a genealogy of urban planning in Ontario and to inform discussions around the discursive production of sustainability and nature in Old Ottawa South. Chapter 5 provides an analytical discussion around the secondary focus of this thesis: discourses of community and heritage in Old Ottawa South. Finally, Chapter 6 concludes the thesis with a summary and identifies both the contributions of and limitations to the research. It also offers some final thoughts about the challenges that communities face when dealing with those advocating 'intensive' urban development and how communities can engage with government policies and respond to development pressure, all within the framework of resistance to hegemonic discourses that undermine contingent futures of possibility. 


\section{Chapter 2: Conceptual Framework}

Both the academic and 'popular' literature on urban sustainability fail to adequately interrogate sustainability as a concept, investigate its deeper meanings, and examine its tensions and contradictions. As such, sustainability remains largely under-theorized. Many authors and organizations have attempted to define criteria for sustainable urbanism, often resorting to general principles and indicators that are proposed to guide and judge, respectively, the degree to which a city can achieve (usually environmental) sustainability (Campsie, 2001; Roseland, 1992; UNEP, 2003). However, policy initiatives and practices that seek to incorporate these principles result inevitably in certain unintended and unforeseen consequences, as particular forms of sustainability are co-opted by policy-makers, developers, and other special interests, for political and economic purposes.

Chapter 2 outlines the conceptual framework and theoretical basis for this thesis: one which moves away from analyses of best practices for normative sustainability strategies, toward developing a critical appraisal of how sustainability is used, with a view to understanding the practical consequences of municipally-imposed sustainability policies and practices. Within this critical evaluation of sustainability, this research is informed by poststructural political ecology, which examines socio-environmental relations that focus not only on the practical ways that social actors and institutions relate to the environment, but also on the way meaning is iteratively produced in terms of how society constructs knowledges of what counts as 'nature' (Braun \& Wainwright, 2001) and how and for whom nature is to be valued and managed. 


\subsection{A Critical Approach to Sustainability}

This thesis draws on scholarship based on a critical analysis of sustainability. An extensive literature on urban sustainability deals with sustainability as a normative concept - one that is prescriptive and aimed towards achieving particular goals - based on planning models and technological 'advances'. This type of analysis often focuses, for example, on the degree to which the physical form of a city, the intensity of activity within it, and innovations in technology can contribute towards its sustainability. Municipalities are increasingly linking urban form with public transit through such models as 'transit-adjacent development', 'transit-oriented development', and other variations of 'transit-supportive urban form' (Renne, 2009). Kenworthy (2006) explicitly outlines 10 key principles vis-à-vis transportation and urban form with his 'eco-city dimensions' that include wide ranging criteria intended to move a city toward sustainability. ${ }^{13}$ Other authors attempt to describe urban sustainability by using language that speaks to quality of life, safety, affordability, and self-sufficiency, while reducing the impact on the environment (Maxwell, 2003; Roseland, 1992; Wheeler, 2003).

Interestingly, the work of authors such as Maclaren (1996) and Gahin and Paterson (2001) has shown that sustainability indicators can function not only to measure or monitor the progress of urban sustainability initiatives, but also to facilitate social change (albeit slowly) by engaging and reinforcing urban sustainability within the public discourse.

\footnotetext{
${ }^{13}$ The 10 'eco-city' principles revolve around public transit and pedestrianism instead of personal automobiles, compact use of space and efficient use of resources, the embracing of 'nature' within and outside of the city, well designed, vibrant, and accessible public spaces, appropriate use of technology, and democratic and consultative decision-making.
} 
While recognizing the value of research on normative approaches to urban sustainability, this thesis departs from analyses that attempt to define or measure the sustainability of a city and instead adopts a critical interrogation around the ways in which sustainability is often co-opted by various groups (including governments, real estate developers, and city planning experts, among others) for specific and often political purposes (Zeemering, 2009). For example, Raco's (2007) assessment of urban policy in the United Kingdom in the 2000s uncovers how 'sustainability' is being used to justify repressive and contradictory policies that, rather than making cities more inclusive, make them more exclusive and elitist. In the North American context, several authors focus on tensions and contradictions with sustainability initiatives based on compact cities and urban intensification, particularly as existing neighbourhoods become sites for these initiatives (and associated neighbourhood changes) even while municipal policies continue to encourage sprawl (e.g., Bunce, 2004). Other authors are critical of initiatives, such as Smart Growth (Bunce, 2004; Bruegmann, 2005; Grammenos, 2007), that prioritize growth and development over meaningful sustainability targets, but often fail to deliver the expected reduction in ecological footprint that justified the initiatives.

Gandy (2006) criticizes New Urbanism ${ }^{14}$ in particular, not only for its prescriptive requirements, but also because it relies on nostalgia for the past and perceptions of "superiority of small-town life within which ideological motifs of stability and sustainability draw heavily on nature-based conceptions of urban design" (p. 66). For

\footnotetext{
${ }^{14}$ New Urbanism is primarily a 'neo-traditionalist' urban design and architecture movement (Katz, 1994) that seeks to 'create community' through urban design, specifically applied to the neighbourhood level (Calthorpe, 1993), with the ultimate goal of reducing sprawl and increasing pedestrianism through the application of (at last count) 27 specific design principles (see CNU, 2001).
} 
Marshall (2000), these ideological notions are part propaganda and part sales pitch, forwarded by New Urbanists to legitimate urban sprawl while concurrently claiming to provide its antidote. New Urbanism also purports to produce specific social conditions and human behaviours (resulting in reduced crime), by creating 'ideal' mixes of low income and middle class housing, and 'creating community' through urban design (Duany, Plater-Zyberk, \& Speck, 2000).

According to Talen (1999), New Urbanism relies on the importance of 'sense of community', assumes the existence and virtues of this sense as pre-given, and deems as logical the notion that 'sense of community' can be created via an ideal organization of space (New Urbanism will be discussed further in Chapter 5). Furthermore, Harvey (2003) posits that many urban planning models are an expression of utopian visions that use imagination and desire in an attempt to create cities where "history may stop ... harmony will be established ... [and] human desires will once and for all be fully satiated" (p. 88). For Harvey, difference and change are central to urbanity, and utopian planning models often serve to repress these qualities of human desire. Yet many planning models do exist; and not necessarily for the explicit aim of satiating all human desires, but rather for the purpose of realizing specific social goals such as equality, cultural diversity, and (most importantly for this discussion) sustainability (ibid.).

\subsection{Poststructural Discourse Theory and Sustainability}

A move away from research based on evaluations of (practical) normative approaches to urban sustainability is evidenced in a growing literature that focuses on how meaning is produced and normalized through language and practice. A leading thinker in the 
production of knowledge through language was Michel Foucault, and his writings on discourse have greatly influenced the scholarship on how knowledge is produced, how it is privileged, and how power operates in the production of knowledge (see for example, Foucault, 1969/1972; 1973/1994a; 1982/1994c). In an explanation of discourse theory, Peet and Watts (1996) describe Foucaultian discourse as "an area of language use expressing a particular standpoint and related to a certain set of institutions ... [a] discourse emphasizes some concepts at the expense of others" (p. 14). Thus, discourses are not objective truth statements about reality but rather they rely on socially constructed "discursive formations" (ibid.) constituted by claims to truth. Furthermore, discursive regimes or practises "govern what can be said about entities in the world at any given time and place" (Braun \& Wainwright, 2001, p. 46). Knowledge, therefore, is produced "as an effect of power" (ibid.) under the discipline of a particular discursive formation.

This Foucaultian conceptualization of power, however, is not simply the imposition of a repressive authority on a weaker subject. Discourse is powerful because it produces the way subjects understand the world and these understandings become normalized to the point where discourses can be understood as disciplining subjects to think and act in certain ways (Foucault, 1982/1994c; Rose, 2001). Power, according to Foucault (1982/1994c) "brings into play relations between individuals (or between groups) ... [t] he term 'power' designates relationships between 'partners' ... of an ensemble of actions that induce others and follow from one another" (p. 337). Foucault further explains the exercise of power in a 1980 tape-recorded interview with then graduate student Michael Bess: 
What does it mean to exercise power? It does not mean picking up this tape recorder and throwing it on the ground. I have the capacity to do so-materially, physically, sportively. But I would not be exercising power if I did that.

However, if I take this tape recorder and throw it on the ground in order to make you mad, or so that you can't repeat what I've said, or to put pressure on you so that you'll behave in such and such a way, or to intimidate you - well, what I've done, by shaping your behavior through certain means, that is power ... I exercise power over you: I influence your behavior, or I try to do so. And I try to guide your behavior, to lead your behavior. The simplest means of doing this, obviously, is to take you by the hand and force you to go here or there ... it's actually in that moment that power ceases to be power and becomes mere physical force. On the other hand, if I use my age, my social position, the knowledge I may have about this or that, to make you behave in some particular way - that is to say, I'm not forcing you at all and I'm leaving you completely free - that's when I begin to exercise power. It's clear that power should not be defined as a constraining act of violence that represses individuals, forcing them to do something or preventing them from doing some other thing. But it takes place when there is a relation between two free subjects, and this relation is unbalanced, so that one can act upon the other, and the other is acted upon, or allows himself to be acted upon. Therefore, power is not always repressive. It can take a certain number of forms. (Bess, 1988, p. 2)

This quotation highlights particular 'features' of a Foucaultian conception of power. The most important is the notion that power is exercised through influence and coercion; acts of violence in repressed subjects are not exercises or examples of power, but are merely force applied on subjects against their will. The absence of force - or at least the absence of a requirement of force - within Foucault's conceptual understanding of power implies that subjects are 'free' and willing to act in specific ways. But the exercise of power also implies an imbalance: relationships of power are actions by one upon another. Foucault (1994c) further explains the difference between power and force in terms of the actions of subjects. According to Foucault, "what defines a relationship of power is that it is a mode of action that does not act directly and immediately on others. Instead, it acts upon their actions: an action upon an action, on possible or actual future or present actions" 
(1994c, p. 340). In other words, subjects are powerful if their actions induce others to behave in particular ways: perhaps immediately - perhaps in the future. It is not a matter of direct force: causing one to act against their will. Rather, power operates by convincing others to willingly act in particular ways.

Determining how power should be exercised - what 'appropriate' power relations are - is not something that Foucault is willing to propose. However, he does suggest that where power is being exercised by one over the other, this imbalance implies that power will always be resisted, even if it is tolerated for a time:

... acceptable conditions for the exercise of power cannot be defined a priori. They are never anything but the result of relations of force within a given society. In such a situation, it happens that a certain disequilibrium in the relations of power is in effect tolerated by its victims, those who are in the more unfavorable position for a period of time. This is by no means to say that such a situation is acceptable. They become aware of it right away, and so - after a few days, years, centuries-people always end up resisting, and that old compromise no longer works. That's all. But you can't provide a definitive formula for the optimal exercise of power. (Bess, 1988, p.11)

Foucault's framework of power and knowledge is a useful way to theorize the operation of power and the production of knowledge within such institutions as the Government of Ontario and particularly the quasi-judicial body that often makes final decisions vis-à-vis development approvals in Ontario: the OMB (although this thesis only peripherally addresses the provincial level of government in Ontario and thus discusses power within the OMB only briefly, with the understanding that more work is needed on this topic). Yet the above statement, particularly the use of the terms 'disequilibrium' and 'victims', suggests that democratic principles are not always at play under the exercise of power. Conceptualizing the operation of power in institutions, such as the OMB, reveals the 
tensions between the subject and object of power, and the (un)democratic processes that result in compliance or resistance to a disequilibrium in the power relationship.

Although Foucault clearly shows that power and force are not the same, he is less clear about the point where power and mere force 'meet' and this is particularly relevant within relations that appear to be ones of repressive authority upon a weaker subject. For example, within such a dominant institutional regime as the OMB, and the Government of Ontario in general, how can we conceptualize the legalistic environment of OMB proceedings that privileges expert 'elites'? To what extent is power being exercised, that is, a normalization in the particular way that the OMB proceeds, such that it is accepted by society and taken for granted in the day to day functioning of land-use regulation in Ottawa (and the rest of Ontario)? Is this power or mere force? Does 'mere force' have to be physical or can it be exercised through, for example, economic or political elitism? Can subjects be considered 'free' if they are excluded from decision-making processes, with little opportunity for inclusion? Foucault describes power as actions that induce others to willingly act. But how does one conceptualize 'willingness'? Can willingness be induced to the point where it is 'forced' willingness? Although this thesis does not resolve these questions, it elaborates more fully in Chapters 4 and 6, Foucault's explanation of power within institutions.

Not only are power and knowledge "woven together" (Foucault, 1973/1994a, p. 32), but also discourses are constitutive of particular knowledges that have practical implications. Rose (2001) explains how discourse is related to practice: "[d]iscourse ... refers to groups of statements which structure the way a thing is thought, and the way we 
act on the basis of that thinking ... [d]iscourse is a particular knowledge about the world which shapes how the world is understood and how things are done in it" (p. 136). Gunder (2006) portrays sustainability as a set of contestable discourses and practices that planners and politicians selectively use for their own 'ideological' purposes. According to Gunder, discourses of sustainability have been "deployed selectively by planners or politicians as a materialization of dominant institutional ideologies supportive of growth and capitalist accumulation that maintains the existing status quo of class inequalities, with limited regard to the environment ${ }^{15 "}$ (p. 209).

Similarly, Escobar (1996) is critical of discourses of sustainable development that privilege the 'management' of nature for the purpose of capitalist accumulation (although Escobar, drawing on Foucault and poststructural theorizing, would unlikely use the term ideology ${ }^{16}$ ). Escobar explains that discourses of sustainable development stemming from Our Common Future (WCED, 1987) reworked 'nature' into the commodity 'environment'. This commodity was then seen as something that could be managed, controlled, and protected, but whose ultimate purpose was to provide a form of capital for the ever-expanding market economy. It is not surprising then, that planners and policy-

\footnotetext{
${ }^{15}$ The growing literature around critical urban theory examines the effects that the dominance of capitalist accumulation (the 'violence of capitalism') has on the way that cities develop and are governed. See for example, the special issue in the journal CITY, aptly titled 'Cities for People, not Profit' (volume 13, numbers 2-3, June-September 2009).

${ }^{16}$ Foucault had little use for 'ideology' as an explanation of the operation of power and the production of knowledge (Ekers \& Loftus, 2008; Foucault, 1973/1994a). Foucault (1973/1994a) explains how ideology as a concept is often used to describe forms of power and knowledge that reflect particular practices (in his example, the particular practice in question was the capitalist system of production). Foucault explains that power and knowledge are much more complex than simple reflections and enabling factors; "[p]ower and knowledge ... are not just superimposed on the relations of production, but rather are very deeply rooted in what constitutes them" (p. 87). Thus, knowledge is produced through "[a] web of microscopic, capillary political power" that repositions the source of power not simply with elitist, institutional, or government apparatuses, but with the lowest levels: what Foucault (1973/1994a) calls 'infrapowers', that proliferate and are constitutive of norms (as well as 'expert' knowledges) - not easily or fully explained by 'ideology'.
} 
makers would co-opt the concept of sustainable development; for as Escobar (1996) explains: "the sustainable development discourse purports to reconcile two old enemies economic growth and the preservation of the environment - without significant adjustments to the market system" (p. 49). Sustainable development, therefore, is a useful concept by which the planning of urban form and the policies governing its development can carry on with minimal (and mitigable) disruption, as long as the environment is being 'protected' (and continues to exist as capital).

Although sustainable development may not be synonymous with sustainability, Gunder (2006) sees sustainable development as a particular discursive reworking of sustainability that places as much or more emphasis on economic growth (the development portion of sustainable development) than on the social or environmental aspects of sustainability. Similarly, Escobar (1996) argues that constructing nature as commodity effectively condenses the three pillars of sustainable development to one: sustaining nature as a resource (p. 49). Bunce (2004) illustrates how sustainable development applied to urban development has largely been co-opted by property developers and policy makers in Toronto to enable economic growth. She argues that urban intensification in Toronto in the late 1990s, based largely on Smart Growth principles, had as its main the goal the revitalization of the urban core in an effort to increase investment, labour, and overall economic growth: "[t]he environmental benefits of urban intensification are used as a softer approach to selling the idea of intensification to existing residents of Toronto; in particular, to residents who are sympathetic to environmental concerns and who might otherwise be opposed to a straight-ahead plan for 
economic revitalization" (p. 188). In this framework, portraying intensification as a sustainability initiative serves to legitimate developments that might otherwise be more widely contested: claims to sustainability make development accepted and acceptable.

Recently, researchers have focused on contributions of sustainability discourses to 'policy space', where principles of sustainability as they apply to urban development are linked with local politics, providing opportunities to rework existing policies or develop new ones to address problems (Mendes, 2007). In this framework, sustainability is understood not as the application of a planning model, but "as a governance project involving trade-offs between various actors and interests in the resolution of conflicts ... [that] moves beyond the question of whether sustainability is on or off a municipality's agenda and focuses instead on the ways in which sustainability issues are defined and incorporated into strategies and policies locally, and the type of governance that ensues" (Mendes, 2007, p. 95; see also Zeemering, 2009 for a discussion about how local municipal governments incorporate sustainability initiatives within exiting policy or alternatively, create 'new' policy space for sustainability). Thus, sustainability can be understood as a growing discursive terrain, rendered powerful by its ability to produce certain political ends. In this context, the scales at which sustainability issues are contested and negotiated are central, with a focus on "how scalar discourses and practices are mobilized by various actors to achieve particular outcomes" (Mendes, 2007, p. 96, emphasis in original).

It is important at this point to differentiate between two concepts of scale: 'scalar discourses' and 'discursive/social constructions of scale'. By scalar discourse I simply 
mean a discourse that draws on scale (such as local and global) to produce its meaning. This relates to the second notion of scale: the discursive construction of scale - meaning that scale, like all other discourses, does not pre-exist inherently, but is socially produced. Critics of this framing of scale question the utility of scale as a conceptual device, particularly when research around scale seems largely preoccupied with global processes (see for example, Brenner, 2001; Marsden, 2000; Swyngedouw, 1997). Marsden (2000) interrogates the limits to scalar research, although her criticism stems from a materialist analysis of scale - one that frames the material embodiment of scale as the starting point for her critique of scalar analyses. Poststructural theorizing around scale begins with its discursive production and analyzes the material effects that stem from the discursive normalizing of scale as a tangible concept. Thus, the existence of scale is not pre-given but relies on those who give it meaning and use it for specific purposes. The existence of scale as a discursive construction means scalar discourses are imbued with power; different social actors privilege particular knowledges of scale, in effect creating powerful and practical meanings around, for example, local, global, or (as authors such as Swyngedouw, 1997, would suggest) 'glocal'. As Chapter 4 illustrates, social constructions of local and global produce powerful and hierarchical effects around urban sustainability, as expert and globally constructed knowledges legitimate localized practices that become social norms - in effect shifting power by drawing on globalized discourses of sustainability and rendering more localized initiatives powerful.

Several authors (e.g., Robinson, 2009; Zeemering, 2009) illustrate scalar constructions of urban sustainability by analysing ways that different municipalities draw 
on global discourses of sustainability as they develop their own municipal policies and land-use planning practices. However, an examination of the degree to which scalar characteristics appear to be vertical (hierarchical) or horizontal can give at least preliminary insights into the power that different social actors (community members, community association representatives, city councillors, municipal planning experts, and developers) have to influence particular outcomes. But the vertical or horizontal nature of sustainability initiatives also highlights the degree to which governments either co-opt sustainability for the purpose of creating specific top down policy, or open up this 'policy space' to individuals and collectives of individuals as well, in a democratic and consultative manner (or are pressured politically to do so by social actors such as community associations and the media, especially at election time). As this thesis shows, particularly in Chapter 4, discourses of sustainability in Ottawa appear to exhibit scalar (and generally vertical) characteristics: the Province of Ontario constructs municipalities as local 'sites' for sustainability initiatives and municipalities apply these initiatives at the neighbourhood level through land-use mechanisms such as zoning and density targets.

This vertical hierarchy (or claim to hierarchy) is in itself a form of power, as it serves to privilege particular knowledges and practices, and incorporates measures to encourage their continued stability. Yet Foucault's theorizing of power suggests that within this hierarchical framework, power operates and is exercised, not only by those in 'powerful' positions (political decision-makers and the staff who execute their policies, wealthy elites, 'experts'), but also within all the micro-level practices or 'infrapowers' (Foucault, 1973/1994a) that for whatever reason have the ability to influence and even 
rework hegemonic discourses. The challenge for this analysis of power, therefore, is not to assume that elitist and authoritative power is necessarily more able to 'induce' others to behave willingly in particular (normalized) ways (Foucault, 1984/1994c), but to also interrogate critically other sources and exercises of power. This challenge is particularly important when seemingly hegemonic government bodies, such as the OMB, continue to use an 'authoritative' power, and when resistance to this power is relatively widespread and vocal, but seemingly too weak to shift the power relationship. I reiterate here the question I posed earlier in this Chapter: is this the exercise of power or mere force? Are those influenced by OMB and other provincial policies free subjects or are they 'forcefully' constrained by such things as economics? If resistance takes years - even centuries - as Foucault suggests is possible (Bess, 1988), at what point can a regime of power be considered to be operating forcefully? These tensions between power and the OMB, as well as other government/institutional organizations, will be discussed (although not finally resolved) throughout this thesis.

\subsubsection{Discourses of heritage and community.}

The scalar framework outlined by Mendes (2007) is a useful approach for examining the discourses and practices of actors both at the neighbourhood scale in Ottawa and at municipal and provincial scales, with a particular focus on how infill and re-development are seen to contribute to or conflict with sustainability initiatives. Within the context of sustainability, social actors mobilize other discourses in an attempt to influence policy and achieve practical results. For example, at the local scale in Old Ottawa South, individuals and OSCA refer to 'local', 'neighbourhood', 'community' and 'built heritage' 
when negotiating a place for their vision of sustainability (e.g., see OSCA, 2006, for links between 'heritage', 'Smart Growth', and 'vibrant community'). This thesis focuses on discourses of sustainability, community, and heritage, with particular attention to the effects of scale on these discourses. Both community and heritage are discursively produced, are shifting constructs, and can be used to influence hegemonic discourses of sustainability, such that communities may have the opportunity to rework sustainability to prioritize community identity within sustainability initiatives.

As has been extensively discussed in the literature (e.g., Talen, 1999), 'community', including the specific heritages it claims, is neither stable and homogenous nor necessarily spatially defined. Old Ottawa South may have its 'official' geographic boundaries (recall Figure 1.1), it may have certain structures that are shared by residents who live within this geographical area, and there may be a perceived tendency for this 'community' to have certain political and 'ideological' leanings. However, any placement of these individuals into a stable and homogenous construction of community fails to reflect accurately the complexity and difference that these individuals comprise. It also binds them to certain ways of being and undermines their citizenship at other scales of involvement and belonging. As Liepins (2000) explains: "people within a 'community' may also be multiply located in a range of positions, groups and networks beyond the 'community' in question" (p. 327). This is consistent with the 'non-place sense of community paradigm' as described by Talen (1999), where sense of community, rather than being linked strictly to locality, is related more importantly to social factors such as socioeconomic status, age, and gender. Spatially focused constructions of community, 
therefore, fail to account for the diversity of relationships within and across neighbourhood boundaries. As Liepins (2000) notes: “discursive constructions of 'community' can be read for the diversities, silences and marginalisations that occur between competing notions and different social groupings within a given 'community"' (p. 327). Furthermore, questions of whose heritage is claimed, and the motivations for doing so, can be addressed by engaging with the exercise of power within a discursively constructed community.

Despite this diversity, complexity, and heterogeneity of community members, discourses of community are often strategically mobilized and community identities are socially constructed for specific purposes, such as to oppose development projects (Colombo \& Senatore, 2005; Dalby \& Mackenzie, 1997; Liepins, 2000). In this context, community identities are not pre-given categories, but are performed and are shifting continuously in a constant process of becoming (Butler, 1992; Pratt, 2004). In Old Ottawa South, contested redevelopment projects in the last several years have mobilized individuals to engage as a community. Thus, the conflicts themselves may serve to (re)produce community identities - a concept to be explored throughout this thesis.

\subsection{Political Ecology and the Social Construction of Nature}

This thesis can be situated within the field of political ecology - a conceptual framework that merges insights from political economy and cultural ecology (see for example, Blaikie \& Brookfield, 1987; Escobar, 1996; Paulson, Gezon, \& Watts, 2003; Peet \& Watts, 1996). An extensive body of literature has also developed around urban political 
ecology, largely from a marxist perspective. ${ }^{17}$ Urban political ecology is an approach used to theorize the complex ways that human society interacts with a socially constructed urban 'nature' (Heynan, Kaika, \& Swyngedouw, 2006) or as Keil (2003) states: "an analysis of political economy that starts taking nature seriously" (p. 726). The political economy portion of this framework highlights the role of a democratic governance system that forms the backbone of municipal politics in the Canadian city ${ }^{18}$; political ecology places the construction of nature firmly within this realm. As Keil (2003) further explains:

... the ways in which we regulate and govern ourselves, and the urban-nature relationships that sustain our cities, are largely matters of the political regulation of urban nature. Urban political ecology - the regulation of our relationships with nature in cities - is ultimately a question of democracy, governance, and politics of everyday life in cities. (p. 729, emphasis in original)

A key component of urban political ecology is the idea of a socially produced nature, and more specifically, a socially produced urban nature.

A marxist approach is largely preoccupied with the capitalist production and regulation of a material nature, and consequently, uses analogies such as 'metabolism' and 'circulation' as metaphorical comparisons of the city to the complex workings of the (human) body (Heynan et al., 2006). Within a historical materialist approach that draws on concepts of metabolism and circulation, humans transform nature and are conversely

\footnotetext{
${ }^{17}$ I have adopted a 'small m' marxism, similar to Ekers \& Loftus (2008), who note that "marxism is a terrain of debate and not a singular canon" (p. 705). Similarly, Foucault (e.g., 1973/1994a) qualifies 'marxism' with such phrases as "[a] certain university or academic tradition of Marxism" (p. 3), or "a certain conception of Marxism that was imposed on the university" (p. 15), suggesting that there is no one 'marxist' theory, or 'Marxism', but rather certain ways of theorizing Marx.

${ }^{18} \mathrm{An}$ in-depth summary of municipal governance structures currently operating in Canadian cities is beyond the scope of this thesis. See Sancton (2004), Reese (2004), and Rosenfeld and Reese (2003) for discussions about municipal governance and amalgamation in Canada.
} 
transformed by it, the main purpose of this relationship being the appropriation of nature for the purposes of its commodification in a market economy (Castree, 2001; Heynan et al., 2006; Kaika, 2006). Heynan et al. (2006) give specific examples of the transformation of nature (creation of urban parks, construction of skyscrapers, and diversion of rivers) and refer to this transformation as "the metabolic production of use values" (p. 8). The starting point for this marxist analysis of nature is a 'pristine' or 'first' nature. According to Kaika (2006), the urbanization of nature is a "socioenvironmental and inherently political process ... as part of modernity's quest to conquer and urbanize nature" (p. 277). Kaika then goes on to describe the construction of the Marathon dam in Athens as symbolic of this conquering and transforming of nature. Such a feat of human ingenuity "signaled the moment when nature's water could be controlled and channeled ... and announced a new relationship between nature and the city" (ibid., p. 295); this 'new' nature supposedly contributes to Athens' improved metabolic efficacy, but in so doing, further contributes to the city's dependency on the continued production of nature by society.

\subsubsection{Contributions from poststructuralist theory.}

Largely absent from the urban political ecology literature is a recognition that meaning is socially produced and that societal relations with nature are more complex than can be described by a pristine 'first nature' versus a human-altered 'second nature' binary. A poststructuralist interpretation of social nature, which insists that "there cannot be a materialist analysis which is not, at the same time, a discursive analysis" (Escobar, 1996, p. 46), provides a more useful approach for this thesis. Similarly, according to Castree 
(2001), the way that society perceives, interacts with, and 'remakes' nature is socially constructed such that nature is discursively produced rather than readily apparent and pregiven in its understanding. This represents a shift in analysis "from questions of nature's material existence and transformation to questions of epistemology" (Braun \& Wainwright, 2001, p. 41). Central to this type of analysis are questions of why a particular type of knowledge is accepted and dominant as opposed to alternative conceptualizations and representations, how a certain type of knowledge is produced and reproduced, and what processes lead to its continued existence and stability (ibid.; see also Foucault, 1969/1972, and Foucault, 1973/1994a). Furthermore, an epistemology, “a set of implicit or explicit principles and practices by which one comes to know the world" (Braun \& Wainwright, 2001, p. 61) as it applies to nature, does not develop and exist inherently or independently. It is produced as an effect of power via those individuals, institutions, practices, belief systems, and any number of other factors, that influence the discursive construction of nature (ibid., pp. 41-42).

Social nature, the idea that nature is discursively produced, is a useful approach for understanding how different constructions of nature can be co-opted in the mobilization of sustainability discourses. Although the language of sustainability in an urban context may superficially seem rather distant from that of 'ecological sustainability', discourses of nature are nevertheless important to urban sustainability; 'the environment', as the first pillar of sustainability, is often the primary focus of urban sustainability strategies (as they are presented in official municipal documents). Furthermore, particular constructions of nature are used to produce what Heynan et al. 
(2006) refer to as "environments that embody and reflect positions of social power" (p. 9). We can see evidence of power in the way that the City of Ottawa uses discourses of nature to determine how development should occur in Ottawa. For example, the greenbelt in Ottawa is a model of what counts as 'nature' and it introduces a physical and symbolic delineation to the city, separating the 'built' and 'natural' environments. Ironically, beyond the greenbelt in Ottawa, nature seems to be getting less 'valuable', as most development in the City of Ottawa currently occurs outside the greenbelt (Ottawa, 2006c). The Ontario Greenbelt in the Greater Toronto Area is used as a literal and symbolic separation of urban and rural: it is intended to protect agricultural land (and other 'environmentally sensitive' land) from the encroachment of urban development (Turvey \& Konyi, 2009). Green spaces, parks, and special conservation areas are also used to 'create' nature and are often seen as progress towards sustainability (see for example, Ottawa, 2007d).

These are relatively benign examples of what Braun and Wainwright (2001) explain as the material effects of the production of a certain type of knowledge about nature, in terms of what counts as nature, how nature is valued, and how it is used. Furthermore, these examples do not even begin to describe the myriad ways that discourses of nature and sustainability are used in the day-to-day affairs of municipal politics and the incremental decision-making process within which Ottawa City Council operates. Yet these examples highlight the justifications that are used to shape the landscape in a particular way, or to introduce policies that influence the patterns of urban 
development that have consequences for the city dwellers who have their own visions of what counts as nature and what sustainability entails.

Using urban political ecology, particularly within a poststructuralist framework, discursive constructions of nature can be analyzed to gain insights into how community members create nature in order to empower their own positions. Furthermore, this thesis seeks to contribute to urban political ecology in a meaningful way, by adopting a poststructuralist approach that disturbs the notion of an 'innocent' form of nature, by recognizing that knowledges of nature are discursively produced, and that this production of nature is key to the analysis and understanding of the material effects of a socially constructed nature. 


\section{Chapter 3: Methodological Framework}

Chapters 1 and 2 outline the background to the research and the theoretical approach this thesis employs to address the main research objective: to evaluate the ways in which social actors contest the City of Ottawa's sustainable development initiatives by variably privileging environmental, economic, social, and/or cultural aspects of sustainability. Within the context of addressing the research objective, Chapter 3 outlines the methodological framework for this thesis: one which draws broadly on poststructural political ecology and Foucaultian discourse analysis, within an extended case study. This chapter also explains the suite of methods and techniques used to gather and analyze data and some ethical implications of the research project.

Specifically, Section 3.1 outlines the methodological framework in greater detail. In the most general sense, methodology simply refers to the theoretical motivations for how research is conducted, including the rationale for selecting specific methods. However, methodology also involves an examination of how the theoretical approach to research and the particular population being researched informs how research should be conducted, what ethical steps need to be taken, and how researcher positionality influences the knowledge produced from the research (Burawoy, 1998; Harding, 1987). Epistemological questions around how particular knowledge is produced and accepted as opposed to other conceptualizations (Braun \& Wainwright, 2001) are integrally related to methodology, particularly vis-à-vis researcher reflexivity and situated knowledge; Section 3.1 explicitly addresses this. Section 3.2 explains the methods - the techniques 
used to gather data within an empirical investigation (Burawoy, 1998; Harding, 1987) and discusses the rationale for selecting particular methods and participants for the project. Section 3.3 explains the techniques the research employed for data management and analysis and Section 3.4 concludes with a brief discussion of research ethics.

\subsection{Methodology}

Using an extended case study within the community of Old Ottawa South, this research is informed broadly by poststructural political ecology and situated within a methodology framed by Foucaultian theories around discourse, particularly archaeology and genealogy (Foucault, 1969/1972; Foucault, 1977b; Foucault, 1983, April 12). Archaeology refers to the theorizing and analysis of discursive statements and practices (Foucault, 1969/1972, p. 135). Genealogy is a critique of the traditional form of historicizing that privileges particular moments and events from the past, and presents them as singular and linear narratives; genealogy seeks to disturb these narratives by uncovering moments in history that have been silenced or marginalized and by suggesting that other accounts may also constitute historical events rather that those privileged by traditional historical narratives (Foucault, 1969/1972; Foucault, 1977b). In terms of methodology, Foucault (1983, April

12) describes the relationship between archaeology and genealogy:

With the term archaeological research ... what I am dealing with is a set of discourses, which has to be analysed as an event or as a set of events ... [g]enealogy is both the reason and the target of analysing those discourses as events; and what I try to show is how those discursive events have determined in a certain way what constitutes our present and what constitutes ourselves: either our knowledge, our practices, our type of rationality, our relationship to ourselves and to the others. So genealogy is the finality of the analysis and the archaeology is the material and methodological framework. 
In the context of Foucaultian discourse analysis, therefore, archaeology frames the analysis by interrogating what constitutes the 'rules' of particular discourses and how language is used to both reveal and produce effects of truth within particular discourses. Genealogy 'reads' history in an attempt to uncover hegemonic and counter-hegemonic discourses operating within a specific spatial and temporal context. In addition to disturbing linear and simplistic notions of history, genealogy also has implications for discourses operating in the present. Since genealogy questions historical narratives based on the linear progression towards an idealized end, it also places the present as a specific point in history - a complex narrative constituting multiple accounts of history. Thus, present discourses are not independent of the past but are also not simply constructed by history in linear, simplistic, and predictable ways. Investigating the genealogy of ideas vis-à-vis the current operation of discourses is one of the tasks of discourse analysis.

Use of Foucaultian discourse analysis as an analytical method to a large extent informs the methods used to gather data, the types of interview questions asked, and the ways in which textual information is analysed. As such, Foucaultian discourse analysis can perhaps be considered both a method and a methodology. The methodological implications of discourse analysis are discussed further in Section 3.1; the use of discourse analysis as an analytical method is discussed in Section 3.2. The remainder of Section 3.1 elaborates upon the methodology I used - with a particular emphasis on reflexivity and situated knowledge - in an attempt to explicitly explain how the methodology and methods address the central objectives of this research on urban sustainability in Ottawa. 


\subsubsection{An extended case study approach.}

At its most general, an extended case study uses the specific case, such as the community of Old Ottawa South, to extract broader meaning from specific examples, within the framework of a particular theoretical approach (Burawoy; 1998; Van Velsen, 1967). For Burawoy (1998) the 'extended' element refers to at least 4 things (p. 20): extending the observer's role to that of participant; extending the spatial and temporal frame of the research; extending the analysis of power relations from simplistic relations of authority to more micro-level webs of power; and extending theory by keeping an open mind to theoretical explanations. Burawoy (1998) refers to the extended case study specifically in the context of ethnography, as an approach that involves "writing about the world from the standpoint of participant observation" (p. 6), in other words, embedding oneself as a researcher into the community one is researching and gaining insights into the experiences of everyday life for extended periods of time (Burawoy, 1998; Jackson, 2000). My research departs from the 'traditional' ethnographic practice of studying 'others' (Hoggart, Lees, \& Davies, 2002) in that I am researching the community in which I live. I am, in effect, part of the researched population; processes around municipal policy and governance influence what knowledges I privilege and what assumptions I make - a situation that presents me with additional challenges as a researcher.

The purpose of the extended case study is to use the particular case to generate understandings of processes that may have broader significance and application. Hart (2006) further elaborates on the purpose of the case study, particularly in the context of a 'global ethnography': 
Such ethnographies are not accounts of 'local' variations or instances of a 'global' process. Nor are they case studies of the impact of ... pre-given forces. Nor do they simply represent methods for the detailed production of area knowledge. Instead, critical ethnographies offer vantage points for generating new understandings by illuminating power-laden processes ... within and across different spatial scales. (p. 982, emphasis in original)

The point of this approach, therefore, is not to explain how unique, local cases fit into the global picture; the goal is to move past preoccupations with specific arguments centred on local/global binaries and instead to explore connections with people and processes within and across scales (Hart, 2004). Furthermore, by using the extended case study approach, one does not look for simple causal relationships to explain complex concepts; the focus, rather, is on processes by which "multiple forces come together in practice to produce particular dynamics or trajectories, as well as possible alternatives" (ibid., p. 97). Within the broader context of reflexivity and situated knowledge (Burawoy, 1998; England, 2006; Rose, 1997), the intent of this research is not to make generalized and universal claims to truth. The research was approached with the understanding that any insights generated are shaped by a very specific context, within a particular constellation of power relations that cannot help but influence the research (England, 2006). My positionality - my "view of the world from a ... (specific) embodied location" (ibid., p. 289 ) - influences the knowledge I gain from research participants and produce from the research experience. These knowledges are situated, "marked by the contexts in which they are produced, by their specificity, limited location, and partiality" (ibid., p. 288). Some of this specificity relates to my choice of methods, my selection of participants, and the particular methodological framework I used to produce this body of knowledge. 


\subsubsection{Foucaultian discourse analysis.}

As Chapter 2 explains, a poststructural approach to discourse theory departs epistemologically from other theories and analyses of discourse (Tonkiss, 1998) and is primarily concerned with the production and operation of discourses as conceptualized by Foucault- groups of statements and practices that produce particular forms of knowledge and what rules are accepted to produce 'truth' and social norms (Rose, 2001, p. 136;

Waitt, 2005, 164). According to Rose (2001), "[d]oing a discourse analysis assumes that you are concerned with the discursive production of some kind of authoritative account and perhaps too about how that account was or is contested - and with the social practices both in which that production is embedded and which it itself produces" ( $p$. 142). For the purposes of this thesis, the contested development projects introduced in Chapter 1 proved a useful avenue for carrying out archival research. The authoritative accounts can be found in the City of Ottawa publications and/or policies that either enabled these developments or failed to stop them. Similarly, the contesting of these accounts is manifested through such written forms as opinion pieces or community association updates, and also through such practices as meetings and protest rallies.

As a methodology - "a theory and analysis of how research does or should proceed (Harding, 1987, p. 3)" - Foucaultian discourse analysis demands a particular way of conducting research, including choice of methods and strategies for data analysis. Waitt (2005) attempts to outline a methodology for doing discourse analysis, with the recognition that Foucault never explicitly committed to, or was willing to concisely specify, how to proceed with discourse analysis. One important component for 
developing a methodology is to determine what sources of information will appropriately address the research question, given that "[d]iscourses are expressed through a wide variety of written texts, visual representations, and practices" (ibid., p. 176). It is important, therefore, to look for sources that reveal relationships of power, claims to truth, ways of normalizing particular practices and knowledges, and efforts to silence or marginalize practices that are considered different or somehow deviant from these established norms. The selection of methods, including the actual process for doing a discourse analysis, is outlined in the proceeding sections.

\subsection{Methods}

I used mostly qualitative methods to gather information, developed coding systems to organize and facilitate analysis of the information, and then carried out Foucaultian discourse analysis in order to investigate how meaning is produced and how particular truth claims and practices become naturalized though the political effects of power (Foucault, 1969/1972; Rose, 2001; Waitt, 2005). Briefly, I used the following methods:

- analysis of archival material, such as OSCA minutes, newspaper articles (e.g., The Oscar, The Ottawa Citizen), and City of Ottawa official plans;

- semi-structured, in-depth interviews with targeted informants, including representatives selected from the community, the community association, and City Councillors;

- participant observation, particularly at OSWatch meetings;

- discourse analysis of archival texts, interview material, participant observation notes, and community association minutes. 
I used some quantitative data, particularly census records, to provide information about demography, transportation patterns, and socio-economic factors in Old Ottawa South. An analysis of minutes of OSCA meetings, relevant newspaper articles, property developer websites $^{19}$, and City of Ottawa publications (e.g., City of Ottawa official plans and white papers) provided insights into the ways social actors contest and debate municipal decisions and agendas in order to influence outcomes and challenge existing municipal policies and practices. Archival research also allowed me to access statements from social actors that were unable or unwilling to give interviews, helping to include those perspectives that might otherwise remain hidden. Furthermore, as is discussed below, preliminary archival research helped to identify suitable interview participants.

\subsubsection{Interviews.}

I used semi-structured, in-depth interviews to gain an understanding about how individuals, community groups, and municipal governing bodies mobilize discourses to challenge hegemonic discourses and to create space within which they might influence municipal policies and practices. Semi-structured interviews rely on a predetermined line of questioning, but allow for additional questions during the process of the interview (Dunn, 2005). Researchers usually draw on a list of broad questions or topics, but the interview itself proceeds as a conversation, rather than a series of well-rehearsed and carefully worded questions (ibid.).

\footnotetext{
${ }^{19}$ Two developers in particular have recently been involved in development projects in Old Ottawa South, and market community, heritage, and sustainability in particular ways: Campanale Homes (www.campanale.com) and Charlesfort Developments (www.charlesfort.ca).
} 
The strengths of using interviews (particularly semi-structured interviews) as a research method are well documented. Dunn (2005) notes that interviews can be a 'respectful' and 'empowering' method in that participants' views are generally valued by the researcher; interviews may also allow participants to more fully become a part of the research, as opposed to methods that more passively 'use' participants. Valentine (2005) contrasts interviews specifically with questionnaires, noting that interviews give participants freedom to respond openly, as opposed to providing fixed, categorized responses. Interviews also allow participants the opportunity to explain their responses (as I relate in Chapter 4, one participant qualified his answer so much as to [very consciously] change his response 180 degrees), to provide more nuance and to even retailor a question to an area that the respondent is interested in talking about (ibid.).

Valentine (2005) also addresses issues of rapport and range of questioning: whereas questionnaires often seem like 'interrogations', interviews are more conversational and can be more congenial than questionnaires, allowing respondents opportunities to express what they want to talk about or to answer questions in ways that they are comfortable with. In terms of range, questionnaires necessarily must be limited in the breadth and detail of questioning. Interviews, while also time limited, can provide more opportunity for wide-ranging discussion, with as much or little detail as the interviewer and participant wish to negotiate. Valentine brings up one final difference between questionnaires and interviews that is very important to this thesis: that of representation. Questionnaires are generally used to gain representational data: they are conducted in large numbers, are categorical, and are often quantitative, the purpose being 
to 'reveal' statistically definable features of a researched population. Interviews, on the other hand, are conducted to gain insights into the particularities and differences of individual experiences. Interviews also provide researchers with what Waitt (2005) refers to as "qualitatively rich" material, that is, textual statements that go beyond 'yes'/'no' responses, revealing greater meaning around, and engagement with, a particular topic. Within the context of discourse analysis, conducting interviews with a wide range of sources can reveal both dominant and counter discourses, and can give insights into whose knowledge is privileged and whose is silenced or marginalized (Waitt, 2005).

Over the course of approximately eight months, I conducted thirteen interviews with fifteen participants (two interviews were with groups of two participants; the rest were one on one). Participant selection was purposeful: I was not intending to achieve a 'representative sample' of the population within the case study; rather I chose participants based on their perceived ability to make illustrative contributions to this research (Valentine, 2005). Of particular interest to me were the processes through which individual and collective social actors construct meaning(s) of sustainability and contest municipal sustainability policies and practices that threaten their own construction of sustainability. Participants were selected primarily based on their involvement with contested development projects, The Oscar, OSCA, and businesses in Old Ottawa South. Archival research helped to identify key actors surrounding the contested development projects. These included community activists who petitioned against developments and often wrote articles in The Oscar, community association members who attempted to negotiate with the City of Ottawa and developers, and authors of rebuttal articles in The 
Oscar who opposed the positions of those contesting the developments. I contacted these potential participants by e-mail, telephone, or letter (through the mail), with a brief description of my research and a request to participate in the project. I then provided a letter of information describing the details of my research to those who expressed interest in participating. Although many individuals were interested in participating, I was surprised by how many did not respond and how long it often took to receive responses. Chapter 6 includes a discussion around these challenges.

I recruited four participants during the process of participant observation. Although I expected that some individuals would express interest, I again underestimated how challenging it would be to recruit participants; some individuals were eager to participate but many had hesitations and many others failed to respond to numerous inquiries. In a similar vein, I had hoped that either by participant observation or by making contact with existing organizations, I would be able to assemble focus groups. I soon realized that this was unlikely to materialize, as those involved in community organizations, projects, or businesses, have very little extra time, and all preferred to limit their involvement to interviews. Although I am grateful for their participation, this is a challenge I had not anticipated (see also Chapter 6).

For the purpose of semi-structured interviews, I developed two main interview guides: one for business and one for neighbourhood individuals. Within these two categories, I further refined the guides to tailor questions to contested development projects or topics that were most suited to interviewees. For example, I interviewed participants from OSHP with a particular focus on the role of heritage on urban 
development. An important challenge for me was assessing what questions to ask and how to 'categorize' participants. This proved particularly relevant when participants were involved in more than one category of involvement (e.g., OSHP, OSCA, and business). In these cases, I focused on questions that were common to both interview guides and allowed the interviewees more opportunities to guide the interview.

\subsubsection{Participant observation.}

Over the course of approximately fifteen months, I was formally ${ }^{20}$ involved in participant observation in Old Ottawa South. I have also lived in this neighbourhood since 2004, and therefore, my experience within Old Ottawa South extends beyond this formal timeframe. I attended the OSCA Annual General Meeting in April 2009, and thereafter, monthly OSWatch meetings; I also kept abreast of ongoing e-mail correspondence with OSWatch participants. I became a member of OSWatch after the first meeting, as I felt that I could contribute something to the organization, rather than simply observing. I also attended a number of meetings and a rally protesting the development of Lansdowne Park. $^{21}$ In this way, my research perhaps became more activist than I had initially intended, although I never made it my goal to remain a passive observer.

\footnotetext{
${ }^{20}$ This method was made formal in the sense that I made my intentions known at a community association meeting and distributed a letter that described my project. It was also formalized by Carleton's ethics process, which requires a specific time frame for conducting research and a description of methods used as part of the ethics clearance process.

${ }^{21}$ The Friends of Lansdowne Park organized a rally, held June 28, 2009 at Ottawa City Hall, to protest the commercialization and privatization of Lansdowne Park. On this same day, council voted to approve a preliminary proposal made by the Ottawa Sports and Entertainment Group to build a sports stadium as well as commercial and residential developments at Lansdowne Park.
} 
Participant observation, according to Cook (2005), is a method whereby researchers study a community by "deliberately immersing themselves into [a community's] everyday rhythms and routines, developing relationships with people ... writing accounts of how these relationships developed ... and observing a community" (p. 168, emphasis in original). Although participation with OSWatch is not necessarily part of one's everyday rhythm, I indeed developed relationships and as I live in Old Ottawa South, my involvement with OSWatch has become something that has contributed to what I perceive as meaningful community engagement.

I was (and continue to be) involved in OSHP. OSHP is a volunteer group organized in conjunction with OSCA and is devoted to the sharing of historical information about Old Ottawa South, such as photos, maps, stories, and other archival information (OSHP, 2010). This project maintains a discussion group via Google Groups, where members can ask and answer questions and post items of interest to the group. I joined the Google Group in June 2009, both out of personal interest and for the purposes of research, and I have participated in a variety of discussions (many unrelated to this thesis). I also asked the group administrator if I could post my letter of interest on the web site asking if members would be willing to participate in my study. I was granted permission and recruited at least two participants in this way, although the details of this recruitment remain anonymous (participants contacted me by personal e-mail, not within the Google Group). Furthermore, by becoming involved with the group, I gained a greater understanding of how individuals construct meaning of heritage, what they claim as heritage, and how they come to value it. I was also able to analyze my own 
perceptions of heritage in this way and to unpack my own notions of what counts as heritage and why. The Google Group also helped in the interrogation of what is meant by 'community' and introduced additional layers of complexity when individuals do not necessarily meet face to face, but rather communicate by e-mail and through online discussions (although many also know each other and do meet face to face).

Participant observation was successful and rewarding in a number of ways. First, by attending the OSCA annual general meeting as an initial step in my research, I had an opportunity to present my research intentions to the community of Old Ottawa South and met a number of individuals who would become research participants. Participant observation at OSWatch meetings in particular gave me broader insights into what community members say and feel that cannot be captured via analysis of meeting minutes or even interviews. Furthermore, several meetings either organized by OSWatch or attended by OSWatch members involved developers, real estate agents, real estate brokers, local business owners or operators, city planners, and/or the ward councillor Clive Doucet. These meetings were a rich source of qualitative data, involved a wide variety of social actors, and generated important insights into how meaning is produced around urban sustainability and development.

Participant observation also provided an opportunity to observe and reflect upon how individuals interact with each other. This social context was similar to what I perceived would occur in a focus group and ultimately led to a much richer and more nuanced dialogue than what could be expected from interviews alone. In contrast to a focus group, where I would have directed the topics of conversation, the topics of 
OSWatch meetings were not always relevant to my project and I tended to avoid making contributions that would lead discussions in particular ways for my own gain.

One goal of participant observation is to attempt to understand research participants' lived experiences in the context of everyday life (Cook, 2005; Dowler, 2001). As a member of the community of Old Ottawa South, the boundaries of my research field were therefore blurred into the everyday and my own position became part of the research. As Dowler (2001) explains: "[w] hen conducting this type of research, there is no point of entry or exit" (p. 157). On the one hand, my own positionality as a member of the researched community perhaps gave me greater insights into the various issues and perspectives currently operating in the community. On the other hand, I had to be continuously reflexive in order to evaluate how I produced the type of knowledge that stemmed from my research and also to avoid steering the research into avenues that fit neatly within my own preconceptions of what social actors think and represent in the community. In other words, I needed to take special care to interrogate constantly my own positionality and to account for my own knowledge in the research process to the extent that I was able - through an ongoing process of reflexivity.

\subsection{Data Management and Analysis}

In what Dunn (2005, p. 95) refers to as the "mechanical phases" of research methods, I used a variety of recording techniques, personal notes, and archival logs in order to gather and record information gleaned from the execution of the methods. In general, this 
entailed four main forms of data recording. I used a digital voice recorder ${ }^{22}$ and handwritten notes for interviews. I wrote these notes directly on my interview guides and used them mainly to help structure the interview and record non-verbal cues, such as particularly animated portions of an interview or background events not captured by the audio recording. I kept a personal log on my laptop computer, which I used to record my thoughts during the entire research process, from interviewing, to transcription, to writing up. I also kept a small notebook with me at all times, which was particularly useful for day-to-day participant observation notes and for recording notes during OSWatch and other meetings. I often made notes in my personal log that referenced this notebook, but did not always transfer the notebook recordings to my personal log.

The benefits of using a voice-recorder have been widely discussed in the literature (e.g., Dunn, 2005; Longhurst, 2003; Valentine, 2005) and will only be mentioned briefly here. An oft-cited advantage is that a voice recorder allows the interviewer to engage more fully in the conversation and to concentrate on the interview itself, rather than on note taking. A voice recorder also allows for a more accurate record of the conversation; this record can be supplemented with hand-written notes taken during or immediately after an interview (Longhurst, 2003). That said - and as discussed earlier in this chapter - an audio-recorded interview is not meant to be the authoritative record, but rather it is situated: marked by the specific context within which the interview takes place.

\footnotetext{
${ }^{22}$ I used an Olympus DS-40 voice recorder; it has built-in recording settings and noise reduction software that allow one to obtain a recording of reasonable quality even while interviewing in such noisy environments as coffee shops, which I did on six occasions.
} 
However, audio recordings may have a number of disadvantages as well.

Participants may not want to be audio recorded, and when they do, the recorder may introduce a level of formality that may not exist if responses were recorded by hand, and which may prevent interviewees from speaking candidly (Dunn, 2005). Furthermore, audio recorders may be subject to technical failures, which could lead to poor quality recordings or loss of data (ibid.). ${ }^{23}$ All participants in this study agreed to be audio recorded and were assured confidentiality and anonymity (three participants did not require this). Although I cannot be certain, none of the participants seemed distracted or inhibited by the presence of the audio recorder. On two occasions, participants wanted to tell me things off the record, and so I simply turned off the recorder for a period and asked for permission before turning it back on. I did not record any off-the-record information either by audio recorder or by hand, and although as a result I do not have access to this information, I feel that having an off-the-record conversation can build rapport and can be a symbol of trust: participants were willing to share sensitive material with me and they trusted that I would not use it. Other times, participants jokingly talked directly into the audio recorder as they said potentially controversial statements; I took this to mean that they were clearly cognisant of being recorded, but felt confident that the material would be treated as confidential. These moments also lightened up the situation and served to downplay the formality of having one's thoughts recorded, stored, and treated as data.

\footnotetext{
${ }^{23}$ The more obvious 'technical' failures of power failure and data loss are relatively simple to anticipate and prevent: I kept a spare set of batteries with my recorder, and saved all audio recordings on my computer and on 3 different USB memory sticks. I did have some problems with ambient noise, only some of which were solved by the noise cancellation function and recording settings.
} 


\subsubsection{Transcription.}

I transcribed most interviews in their entirety ${ }^{24}$; I translated voice recordings to text as verbatim as possible using a limited selection of punctuation to represent speech patterns. In general, I kept transcriptions free of excessive punctuation, using it mainly for standard grammatical purposes; in limited cases, I used italics for emphasized speech and parenthesized comments to indicate laughter or background activity (see Chapter 6 for more details). I returned transcripts to interviewees who agreed to engage in 'participant checking' - a process through which informants were given the opportunity to verify responses, comment on what was covered in the interview, and have a final opportunity to decide how their statements would be used in the research project (Dunn, 2005).

Although actual text was transcribed verbatim, I make no claims to providing an exact translation of the interviews or to gaining the opinions of interviewees. When I returned a transcript to one interviewee for participant checking, this interviewee remarked on the "laborious inclusion of hesitations, false starts, etc." and jokingly suggested that this might be a psychology study on how opinions are formed. I appreciated this comment because it made me interrogate my motivations for this type of 'exact' transcription, rather than accepting that this is the way to transcribe. I responded to this participant with the following e-mail: "any transcription other than one that is as much verbatim as possible would necessarily require a certain amount of interpretation of

\footnotetext{
${ }^{24}$ Out of thirteen interviews, eleven were transcribed in their entirety. Two interviews were selectively transcribed. One took on an unstructured rather than semi-structured format, was over two hours long, and much of it was peripheral to the research. The other deviated to a large extent from my interview guide, as the participant was very knowledgeable about the history of Old Ottawa South and OSCA, and I chose to concentrate on this rather than following my guide. As such, the interview generated much supplemental information and leads for further potential interview participants, but not necessarily 'useful' interview material.
} 
the conversation and thus, have more opportunity for inaccuracies. In other words, I would be imposing my own interpretation of what is said as opposed to simply writing, to the best of my ability, exactly what I hear." Although at the time I felt this was an adequate response, upon reflection, I am not entirely convinced that this response is satisfactory. This discussion will be elaborated upon in Chapter 6.

\subsubsection{Discourse analysis and coding.}

This section explains the particular way in which I conducted Foucaultian discourse analysis as a way to analyse interviews and archival information, using several key sources including Foucault (1969/1972), Rose (2001), Tonkiss (1998), and Waitt (2005). The actual process of doing a Foucaultian discourse analysis is quite complex and departs from other forms of analysis in a number of ways. Unlike hermeneutic based analysis methods such as content analysis or semiotics, discourse analysis does not use an analytical approach to coding that claims the ability to reveal the real (but perhaps hidden) meaning using a robust and systematic quantitative categorization of data (Rose 2001, p. 138). Neither does discourse analysis explicitly assume that there are hidden messages or additional content outside of what can be articulated through language, although according to Waitt (2005), one objective of discourse analysis is "to explore the outcomes of discourse in terms of actions, perceptions, or attitudes rather than the [sic] simply the analysis of statements/texts" (p. 164-165). Waitt later clarifies his point, however, by comparing discourse analysis to content analysis:

... discourse analysis does not emphasise 'peeling away' the meaning of texts. Rather than uncovering processes operating beneath the surface of texts that operate at the level of the sign, discourse analysis examines how discourses are 
constituted and circulated within texts and representations, which in turn function to produce a particular understanding or knowledge about the world that is accepted as 'truth'. (p. 168, emphasis in original)

While Tonkiss (1998) acknowledges that the overall idea of a text can provide a starting point for the discourse analyst, the text should not be seen as "reflecting reality in a transparent or straightforward way, but [rather] as constructing and organizing the terms in which we understand that social reality" (p. 373, emphasis in original). Thus, in the context of this study, discourse analysis does not strive solely to understand interviewee opinion or to determine whether or not they agree with how concepts such as sustainability are used by groups such as city councillors (although statements of opinion can be useful). The central purpose of discourse analysis is to look for statements and practices that inform the researcher how individuals construct meaning and truth claims, how they legitimize these claims, how other claims to truth are excluded, and what contradictions may exist within statements (Waitt, 2005).

Discourse analysis requires a coding strategy that is quite different from that of other analytical techniques. An important starting point for discourse analysis is a thorough engagement with the relevant texts. This may involve multiple readings, all while attempting to "avoid all preconceptions [since]... it can be tempting to impose an interpretation on a sample discourse ... if this is not supported by the data then it will not yield an adequate analysis" (Tonkiss, 1998, p. 377). In other words, a researcher must immerse oneself fully in the data, all within a reflexive approach based on selfinterrogation that attempts to address why specific conclusions are made and how the data supports any arguments, with the recognition that although this knowledge is 
situated, it can nevertheless be supportable and used to present an argument in a particular way.

Within this immersion of data, coding becomes a process through which the researcher looks for regularities within and across statements and practices. Foucault (1969/1972) uses the term 'discursive formation' or 'discursive division', to describe regularities or correlations between statements or particular concepts and the historical context in which the 'rules' of a particular discourse develop and become accepted. Waitt (2005) describes discursive formations as structures that limit how knowledge is produced: "discursive structures or formations refer to a relatively rule-bound set of statements that impose limits on how we construct our thoughts and statements ... discursive structures inform our understanding of objects and events" (p. 171). Although discursive formations may be described as some form of regularity, these regularities may come from widely dispersed and seemingly unconnected sources, both spatially and temporally, and may rely on specific truth claims for a variety of purposes. As Rose (2001) explains: "part of the power of a specific discursive formation may rest precisely on the multiplicity of different arguments that can be produced in its terms" (p. 156). By reading texts for regularities, one can begin to identify themes that indicate connections between and among texts, even those that seem to have little in common; furthermore, discourses can be revealed by how they work to persuade and produce their effects of truth, and how they use specific terms and arguments to legitimize particular subject positions (Rose, 2001). 
During the process of interviewing and archival research, a regularity emerged that I would consider to belong to a particular discursive structure, and which makes for an illustrative example: Barrhaven as a symbol of (unsustainable) anti-urbanism (see Appendix B). At least four interviewees and a number of newspaper authors made reference to Barrhaven as unsustainable, anti-urban, and reaping the benefits of urban disinvestment. Interview participants and newspaper authors generally portrayed Barrhaven in opposition to what they considered to be sustainable and urban. Therefore, if one wanted to understand what sustainable development should not look like, one would only have to look at Barrhaven, both in terms of building type (large homes with 'endless' lawns and garage-dominated streetscapes) and location (outside of the greenbelt in the sprawling suburbs). Failure to repair downtown infrastructure was caused by expansion of roads and sewers to places like Barrhaven (usually pronounced in particularly vitriolic tones).

I found this portrayal of Barrhaven to be an inexplicably specific example and I have yet to conclude why this portrayal has become a norm to many Ottawa residents, especially when other (older) suburbs could also be described in a similar light. Furthermore, Barrhaven is clearly more complex than the above critics portrayed it (although I did not do this, it would be interesting to interrogate how much specific knowledge of Barrhaven urban residents have). Without becoming overly sidetracked by this one example, the discourse analyst would need to know the following in order to analyse the formation of Barrhaven as a symbol of unsustainable anti-urbanism (according to Rose, 2001, and Waitt, 2005): Who is making particular claims? How are 
these claims justified (through terms, images, practices)? How are contradictions managed; are they overlooked or reconciled in some way? Who is privileged and who is silenced by, or excluded from, this discursive structure? By addressing these questions, the discourse analyst can begin to understand how discursive structures develop and become normalized, and how power operates to give particular statements and groups of statements claims to truth by those who accept and mobilize particular discourses.

According to Rose (2001), the discourse analyst should also look for moments when dissent from a discourse is acknowledged and when work is being done to reconcile conflicting ideas or to cope with uncertainty. As is discussed in Chapter 4, many interview participants attempted to accommodate discourses of urban intensification: even though participants could cite a multitude of examples where intensification was producing harmful effects, most attempted to justify intensification in some way, usually by claiming that it simply had not been done appropriately. Reconciling conflict and contradiction highlights processes of persuasion that otherwise might be difficult to detect; efforts to conform to a discourse or to reconcile with it may show how persuasive it is (ibid.).

\subsection{Research Ethics}

The selection of specific methods and participants, the design of the research instrument, and the timeline of the fieldwork are all closely connected to the identification and examination of possible ethical implications. I completed the formal process of ethics clearance from the Carleton University Research Ethics Committee on June 3, 2009 and began fieldwork shortly thereafter. As mentioned above, I was engaged in some 
preliminary participant observation, which I was able to do prior to official ethics clearance as long as I made my intentions known and participated passively - as an observer only. Within the guidelines of ethical research, I gave all interview participants consent forms and the option of withdrawal from the study at any time. I used an audio recorder for all interviews and as such, took steps to ensure privacy and confidentiality of recorded material. For many interviews, I included the process of participant checking; not all participants desired this due to the time constraints, but many did. This additional step demonstrated researcher accountability and ultimately ensured greater accuracy. My goal was to conduct research in an ethical manner as outlined by England (2006) in her explanation of the researcher-researched relationship in feminist geography: " $[\mathrm{b}] \mathrm{y}$ seeking research relationships based on empathy, mutuality and respect, feminists focus on the informant's own understanding of their circumstances ... rather than imposing our own explanations" (p. 288). By following this advice (and while recognizing the importance of institutional ethics guidelines), the research becomes more of an ethical process itself, rather than one based on the literal procedures and guidelines that an ethics committee requires. 


\section{Chapter 4: The Social Construction of Sustainability in Ottawa}

In Old Ottawa South and Ottawa as a whole, contestations around urban development often reveal competing constructions of what sustainability means and what it should look like when applied to municipal policy, the built environment, and the day-to-day operation of the city. As discussed in Chapters 2 and 3, discourses discipline subjects into thinking and acting in particular ways, although discourses are always resisted by competing discourses that contest the claims of others (Foucault, 1969/1972). According to Rose (2001), although certain discourses tend to dominate, many discourses can be in operation at any given time and different social actors often contest the terms of these discourses (i.e., certain ways of acting, thinking, and/or claiming truth).

As a starting point, many interview participants expressed either aversion to the

term 'sustainability', or an understanding that the term has no one precise meaning: "You keep talking about sustainability and I have no idea what sustainability means. The term simply ... like cigarette smoke, it just goes away. I understand some things, but not ... not that term" (Darryl, male in his 60s). This statement seems to reveal a certain scepticism for 'sustainability' as a useful and meaningful concept. Sustainability is also often perceived as an elusive concept, despite its widespread use in the popular and academic discourse. As one participant explained: "Well you're talking to somebody who used to do a lot of writing about forestry and sustainability and I never got a hold of that concept, properly ... I mean it's so squishy (laughs)" (Lydia, female in her 60s). Sustainability does have specific meaning for many interview participants, but this 
meaning is difficult to pinpoint and is much more complex than the often cited explanation of meeting today's needs without sacrificing the ability to meet future needs (WCED, 1987). Kate, a female local business owner in her early 50s, did use this type of definition as a starting point for what she thought sustainability meant for cities: "[s]o it's that kind of idea that your going to be able to live in comfort and ... into the future without killing so many resources ... I imagine there are many different ways of doing that; I don't imagine that there's only one way." However, several participants specifically applied the concept to the built environment. They focused on processes that describe the way people experience everyday life in all its complexities.

Interestingly, one gets a much different description of sustainability from City of Ottawa publications and practices, such as official plans, white papers, and zoning bylaws that link sustainability with processes of development and growth. Rather than focusing on the day-to-day living and governing of the existing urban realm, these officialized $^{25}$ notions of sustainability privilege processes of change (and more explicitly, growth), while attempting to reconcile their potential negative effects, such as urban sprawl, loss of farmland, and increased resource use (the usual suite of 'negative externalities' attributed to urban growth; see for example, Bruegmann, 2005).

Chapter 4 attempts to unpack the ways in which different social actors and institutions (particularly municipal governments) 'produce' sustainability. Using the

\footnotetext{
${ }^{25}$ While the literal meaning of 'officialize' is "to place under official authority or control" (Webster's Encyclopedic Unabridged Dictionary of the English Language, 1989, p. 1000), I use the term in a slightly different way: as a means through which policies and practices are legitimated within discursive assumptions of authority and control. Thus, once policies and practices become 'officialized' (by such mechanisms as official plans, by-laws, policy statements, and City Council decisions) they can then be considered 'truth', and their rejection can be considered 'deviance'.
} 
results of discourse analysis, this chapter illustrates how dominant discourses are constructed (particularly within an institutional framework), what discursive representations constitute them and render them stable, and what some practical consequences of these discourses might be. As such, Section 4.1 in particular traces a genealogy of institutional discourses in Ottawa that are legitimated and made official by land-use planning and official plans, implicated within the evolving discursive norms that privilege 'development' and growth, and enabled by scalar discourses that draw specifically on international and provincial 'authorities' for legitimacy. From this genealogy, Sections 4.1 and 4.2 discuss the implications of scale on discourses of sustainability and intensification, with a particular focus on how scalar shifts have impacted where and how the City of Ottawa targets intensification as a sustainability initiative and what contradictions it overlooks in so doing. Chapter 4, particularly Sections 4.2 and 4.3, also identifies discourses mobilized by social actors in Old Ottawa South, constructed by contestation, difference, and practices of everyday life that produce different meanings from the dominant and sometimes institutionalized discourses of sustainability as they apply to urban development in Ottawa. Section 4.4 then contrasts institutional constructions of nature with those constructed by interview participants, specifically around what counts as nature and how nature is given value. Finally, Section 4.5 concludes the chapter.

\subsection{Institutional / Officialized Discourses}

Although the governance structure of the City of Ottawa (and Ontario as a whole) has changed over the years, Ottawa and other municipalities in Ontario have operated under 
the authority of the Municipal Act since 1849; the Municipal Act is an authoritative statute whereby the Province of Ontario delegates governance responsibilities to lower tiers of government, including municipalities, while retaining considerable control over how these local governments operate (MMAH, 2003). Since the 1970s, the Province of Ontario has also produced a set of policies to guide those land-use and development issues that have 'provincial interest' (what is now known as the Provincial Policy Statement; Penfold, 1998). ${ }^{26}$ 'Provincial interest' can include sustainable development, particularly since the Provincial Policy Statement focuses on such things as agricultural land, wetlands, and natural resources (ibid.).

In addition to the multi-layered set of Provincial regulations composed of acts, statutes, and policies, land-use decisions are also influenced by the OMB, a provincially appointed 'quasi-judicial' body that has the authority to interpret municipal official plans and sometimes overturn municipal land-use decisions (ibid.). Thus in Ontario, both the provincial and municipal scales of governance, drawing on globalized discourses of sustainable development, influence the practical implementation of sustainable development initiatives. The implications of this scalar engagement with sustainable development and the ways in which scalar discourses of sustainability are legitimized are central to this chapter and will be discussed further in Section 4.4. As the following sections illustrate, the various acts, statutes, and policies of the Province of Ontario

\footnotetext{
${ }^{26}$ See Penfold (1998) for a history of the Provincial Policy Statement. Briefly, in the 1970s the Ontario Provincial Government developed policies for those matters it deemed to be in the interest of the province: natural resources, agriculture, floodplains, wetlands, and housing. In the early $1990 \mathrm{~s}$, these policies were referred to as the 'comprehensive set of policy statements' (MMAH, 1996) and from 1996 to the present they have been compiled into one document called the Provincial Policy Statement (MMAH, 2005).
} 
influence urban governance in specific ways, especially vis-à-vis land-use and development.

Municipalities, and other tiers of government in Ontario, have also operated under land-use policy guidelines of the Planning Act since 1946 (Penfold, 1998). The Planning Act gives municipalities the authority to develop official plans and zoning regulations under specific guidelines that are subject to approval by the Ministry of Municipal Affairs and Housing (MMAH) and which can be appealed to the OMB (MMAH, 2009). ${ }^{27}$ Penfold (1998) has made the observation that the Planning Act, as applied throughout the 1960 s and 1970s, had as its main purpose the management of rapid growth that was occurring in many Ontario cities, especially during the 1960s. It was not until 1983 that the Planning Act changed its somewhat narrow focus on physical land-use issues to broader economic, social, and environmental concerns (ibid.). This trend is reflected in official plans of the Regional Municipality of Ottawa-Carleton (RMOC) and of the City of Ottawa during the 1970s and 1980s, although in the 1990s and 2000s, the focus reverted to physical growth. The following discussion examines the shifting discourses of sustainability and growth within Ottawa's official plans.

\subsubsection{From growth to sustainable development.}

Official plans in Ontario represent a continuum of documents that have evolved over the years in terms of their purpose, their priorities, and the geographic areas that they include.

\footnotetext{
${ }^{27}$ Although the actual process of developing official plans is beyond the scope of this paper, they involve approvals from various legislative bodies including municipal city councils and the Ministry of Municipal Affairs and Housing (provincial). The OMB becomes involved if sections of the official plan are appealed by an Ontario resident, corporation, citizens' group, etc.; the OMB then has the authority to reject the appeals or direct municipalities to amend the official plan (MMAH, 2009).
} 
Official plans were developed for the RMOC from 1969 to 2001 and for some municipalities within the RMOC (such as the City of Ottawa) during this time period (Fullerton, 2005). Official plans take years to develop and comprise a variety of volumes, edited versions, approved versions, and office consolidations. ${ }^{28}$ For example, in 1969 , the newly created RMOC began to develop what would become its first official plan: the 1974 RMOC Official Plan (Fullerton, 2005). Most of this document was developed in the early 1970s but it was not officially approved and consolidated for ease of use until 1983. Thus, policies reflected in this official plan consolidation are based on priorities, debates, and decisions originating in the 1970s. According to this official plan, "policies ... are directed to creating an environment within which the physical, social and mental well-being of all persons who live in the planning area can be advanced" (RMOC, 1983, p. 1.1). Even though the 1974 RMOC Official Plan was largely a reaction to the unprecedented suburban growth of the 1950s and 1960s (Fullerton, 2005), the principles and aims of this plan say little about growth, focusing instead on issues of quality of life and even mental health. The actual details of this official plan do indeed deal with landuse and physical development, but growth is not identified as an overarching priority and the official plan's purpose is constructed as that of providing for the well being of the citizens of Ottawa.

\footnotetext{
${ }^{28}$ Official plans are typically composed of the official plans itself, secondary plans, schedules, maps, appendices, etc. They represent a lengthy process, involving preliminary drafts, revised drafts, council approved versions, amended copies, and five-year reviews. In order to more easily read official plans, they usually are compiled after all edited versions have been completed. This compiled version, which represents the complete works of a twenty-year plan, is referred to as an 'office consolidation' and its purpose is to provide an easy-to-use volume that includes council approved material and OMB-directed amendments. Thus, for example, the 2003 City of Ottawa Official Plan has been consolidated into a document called The City of Ottawa Official Plan: Consolidation - January, 2007.
} 
The next RMOC official plan was developed throughout the 1980 s and was approved by RMOC Council in July of 1988 (RMOC, 1988). This plan more explicitly prioritized growth, although it constructed growth not in terms of physical expansion but as 'development': "an official plan contains objectives and policies for the physical development of a municipality while having regard for relevant social, economic and environmental matters" (RMOC, 1988, p. 2.1). In addition to development, this official plan drew on the three pillars of sustainability as underlying goals within which this development should operate. The three pillars of sustainability-economic, social, and environmental imperatives - were not yet constructed as 'sustainability' but were simply referred to as 'matters' that need to be considered within the process of land-use planning. These three pillars stemmed directly from the Planning Act, 1983, a provincially legislated document intended to manage growth (RMOC, 1988). Thus, in the late 1980s, the idea of growth was present and was fundamental to provincial policies intended to govern municipalities; however, neither discourses of sustainability nor discourses of growth were yet operating and normalized within the RMOC official plan.

The 1991 official plan for the City of Ottawa (as opposed to the RMOC) is the first of either the RMOC's or Ottawa's official plans that explicitly refers to sustainable development. Under the heading 'sustainable urban development', this official plan described what measures the City of Ottawa would need to adopt in order to achieve sustainable development goals:

City Council accepts that change is an on-going phenomenon in cities which must be managed within the parameters imposed by the overriding aim of preserving a lasting habitat for humanity and wildlife. It also recognizes that economic prosperity can provide us with the capability to support wise resource 
management, to meet social needs and to improve environmental quality. Therefore, City Council supports an approach to managing urban development which balances the rights of the individual and the needs of society with the need to conserve our natural resource base and enhance the natural environment, thereby promoting the health of Ottawa's inhabitants and communities. (Ottawa, 1991a, p. 2.2)

This official plan explicitly referred to the Brundtland Report in developing its mission statement and boldly asserted that this mission statement, based on the principles of sustainable development, "is the foundation upon which City Council will guide Ottawa into the future" (ibid.). By embracing sustainable development in such an explicit way within a document made legal by the Planning Act, City Council officialized sustainability and induced the City to govern in a particular way:

Ottawa supports sustainable development as outlined in Our Common Future (the 1987 report of the World Commission on Environment and Development - the 'Brundtland Report'). A 'global agenda for change' was what the Commission was asked to formulate. In the report, a number of 'common challenges' or issues facing all nations are presented: these include population and human resources, food security, species and ecosystems, energy, industry, and cities. A key judgement of the report is that 'humanity has the ability to make development sustainable - to ensure that it meets the needs of the present without compromising the ability of future generations to meet their own needs'. (Ottawa, 1991a, p. 2.1; all punctuation and parentheses in the original)

The 1991 official plan not only signalled a discursive shift towards sustainable development (although not growth explicitly), but it also committed to a global context in which to operate and constructed Ottawa as a city with global responsibilities.

\subsubsection{Scalar discourses of sustainable development.}

Ottawa's 1991 official plan explicitly attempted to engage with the three pillars of sustainable development outlined in the Brundtland Report to incorporate 'global' sustainability strategies within the parameters of 'local' municipal planning. Discourses 
of sustainability operating within the 1991 official plan are clearly scalar discourses that shift responsibility for this global movement to the local level. Robinson (2009) traces how Agenda 21, endorsed by the United Nations Rio Earth Summit in 1992, attempted to link global sustainable development principles arising from the Brundtland Report with local government initiatives. According to UNCED (1993), Agenda 21 is a global strategy that requires local implementation for it to succeed:

... the participation and cooperation of local authorities will be a determining factor in fulfilling its objectives. Local authorities construct, operate and maintain economic, social and environmental infrastructure, oversee planning processes, establish local environmental policies and regulations, and assist in implementing national and subnational environmental policies. As the level of governance closest to the people, they play a vital role in educating, mobilizing and responding to the public to promote sustainable development. (p. 28.1)

Whereas the Brundtland Report was influential to policy development at the municipal level, and whereas Agenda 21 called on local governments worldwide to engage with the principles of the sustainable development, discourses of sustainability in Ottawa as a result have global influences, apparently 'jumping' from the international to the provincial/local scale. Robinson (2009) cites arguments that tangible manifestations of any sustainable development strategies are most likely to emerge at the local level. Similarly, Parkinson and Roseland (2002) offer that "local solutions - envisioned with an understanding of the larger national and global context - have proved to be most effective and in keeping with the principles of democracy and public participation" (p. 412). Despite this claim, many interview participants cite problems with governance and sustainability initiatives in the City of Ottawa for their lack of democratic engagement with the public. 
Despite the apparently progressive sustainability goals of the 1991 official plan and the rescaling of Ottawa into the global, the focus of the official plan remained largely unchanged from that of previous official plans, namely, normative matters of land-use planning. According to Ottawa City Council, land-use planning is an effective means through which sustainable development can be realized: "all physical development relates to the land which also supports all forms of life. Since land is the common element, it is City Council's intent to achieve a balance between maintaining the natural environment in good health and meeting the needs of the human community within it" (Ottawa, 1991a, p. 2.3). This simplistic link between sustainability and land-use is reminiscent of the goals of Smart Growth and New Urbanism, which have been criticized for their proposition that urban form and structural residential arrangements have the ability to solve social and environmental problems (Gandy, 2006). In fact, just as the 1991 plan draws on the Brundtland Report and sustainable development, the next official plan (2003; discussed below) draws on Smart Growth and was developed as a response to the Smart Growth Summit held in Ottawa in June, 2001 (Ottawa, 2003a). Section 4.3 further discusses parallels between official plan policies and Smart Growth in Ottawa.

\subsubsection{Re-prioritizing growth.}

In 2001, a new City of Ottawa was formed via the amalgamation of eleven municipalities from the former Region of Ottawa-Carleton (Ottawa, 2007b). The Ottawa Transition Board, which was developed to facilitate the amalgamation process, predicted that this political restructuring would enable economic and physical growth, with the City of Ottawa using principles of sustainability to manage this growth such that "our natural 
environment and quality of life are preserved and restored" (Whitford, 2001). Seemingly concurrent with the formation of the new and larger Ottawa, a shift is signalled by several municipal documents and programs that move away from discourses of sustainable development towards what can be described as 'sustainable growth'. Whereas the 1991 official plan, in its engagement with the Brundtland Report, was purportedly committed to issues of human resources, food security, species, ecosystems, and energy (Ottawa, 1991a), the new City of Ottawa reprioritized sustainable development towards a focus on how the city would grow. This new strategy was officialized within the 2003 City of Ottawa Official Plan: "the Official Plan provides a vision of the future growth of the city and a policy framework to guide its physical development to the year 2021. It is a legal document that addresses matters of provincial interest defined by the Provincial Policy Statement under the Ontario Planning Act" (Ottawa, 2007b, p 1.2).

Previous official plans attempted to incorporate social and environmental planning strategies within official plan policies (and thus within a legal framework). Although the latest Planning Act (MMAH, 1990) suggests that official plans include "the social, economic and natural environment of the municipality" (part III, 16.1a), Ottawa's latest official plan is explicitly focused on land-use; all other policies have been shifted to supplementary policy documents within the planning process called 'Ottawa $20 / 20^{\prime}$ (Ottawa, 2007b). The City frames Ottawa 20/20 as an overall sustainable development strategy of which the official plan is but a small part; all non-land-use policies have been removed from the authority of the official plan (and the Planning Act) and are now included into a much more flexible process that arguably is more open to interpretation 
by those whose priorities may differ from those of Ottawa 20/20. The practical

implications of this remain to be seen, although my argument is that while provincial and municipal structures (particularly the OMB) continue to exist as authoritative bodies, the land-use arrangement of Ottawa 20/20 privileges capitalist enterprises (i.e., land-use and development) by placing them within the legal framework of the official plan, while excluding non-land-use policies (this planning 'hierarchy' is discussed further in Section 4.5). Furthermore, according to one politician ${ }^{29}$ involved in City Council during amalgamation and the Ottawa 20/20 process, many forces were at work that constrained the ability of the City of Ottawa to make crucial decisions that would have allowed it to work towards sustainability. These forces include the overarching authority of the provincial government operating at the time under the leadership of Mike Harris, which put in place the first budget, the first city manager, and many important staff, without the City of Ottawa having input into these decisions. Constraints also included the need to incorporate eleven official plans into one, many of which were still waiting for approval due to unresolved OMB appeals; some of these appeals ultimately undermined land-use decisions (such as the extent of the urban boundary) that were made in the development of Ottawa 20/20 (and the 2003 City of Ottawa official plan). Thus, Ottawa 20/20 is

\footnotetext{
${ }^{29}$ I cannot name this politician. His/her testimony came during the process of participant observation, where I was involved as an OSWatch member, and where I did not identify myself specifically as a researcher. See Hoggart et al. (2002) for a discussion around the tensions between 'overt' and 'covert' observation. Specifically, they cite difficulties with explaining to everyone encountered during participant observation that one is a researcher and that testimony may be used for research purposes. My general principle was that I explained my position to OSWatch, but couldn't possible keep explaining this to every group that OSWatch became involved with, particularly since most of my work with OSWatch was outside the scope of this project (although in some cases, discussion about my research with neighbours facilitated their involvement in or awareness of OSWatch).
} 
discursively framed as a 'Smart Growth' initiative, but a closer examination reveals some of the contradictions and tensions overlooked by this discursive framework.

Land-use planning is to a large extent about accommodating and attempting to order the physical growth of the city; the discursive shift from sustainable development to the 'sustainable' management of growth that occurred in the late 1990s and 2000s has not gone unnoticed by many community members of Old Ottawa South. One interview participant traces this shift to municipal amalgamation and sees this restructuring as a turning point that normalized discourses of growth at the expense of sustainability: ... Ottawa used to be kind of a leader in this ... when it was the City of Ottawa, before amalgamation, I think ... my sense is the city was much more holistic, organic, dynamic, interested in sustainability, planning, thinking about these things, having conferences and trying to do things that are kind of let's say green. Not anymore. Developers are on the agenda. It's obvious. (Clayton)

According to Clayton, not only did this shift change planning priorities from development to growth, but also this growth has become developer-led, where developers are more influential to planning than such tools as official plans and holistic visions of what Ottawa should be.

One participant points out that not only does the City seem to focus on growth at the expense of everything else, but also the way the city operates seems to create conflict: ... no matter what they do, they seem to create conflict and ... 'cause it seems as if the definition of what they think they should be doing has something to do with growth. I don't know what growth ... seems to mean an economic ... it has an economic component to it. And so we will do whatever is necessary to bring growth. To bring in money ... again, I haven't figured out what they think they're doing at that end. Certainly it seems to directly contradict what most of the people in the various communities want to be doing. And it has a huge - I think hidden, actually - economic component to it that isn't openly talked about. You know, people snipe at some of the councillors for being in the pocket of the builders but it's not actually out in the open. I think in fact that's a huge driving force in what 
happens, but I don't know that anybody's actually sat down and tried to prove that in a kind of overall way, and even if you do, who's going to publish it: the Citizen? (Kate)

This participant makes linkages between growth, economics, conflict, and corruption. For her, essentializing growth comes from fetishist discourses of economic growth (see for example, Schecter, 2005), which are also reflected in such indicators as gross domestic product (GDP), building permits and housing starts, and daily news updates on stock exchange numbers and the state of the global economy. The way that the growth rate for the City of Ottawa was calculated for the 2003 official plan is a direct manifestation of a focus on economic growth. According to Cullen (2010, March) and further explained by city planner Bruce Finlay (2010), the growth rate for the city was calculated not using birth and death rates and immigration numbers, but by economic cycles. Calculating growth in this way was a departure from how it had been calculated in the past and Finlay was at a loss to explain why the change in method occurred. Notwithstanding that the growth rate was grossly inaccurate due to economic downturns especially in the high-tech industry, linking planned growth with economic growth also empowers discursive constructions of sustainability that privilege physical growth and economic increase over community-based priorities that focus on quality of life, social justice, and environmental concerns.

Discourses of growth seem to parallel what Gibson-Graham (2003) refers to as a 'global order', where people are conditioned and disciplined into thinking in particular ways. Within globalizing discourses of economic growth, "[b]ecoming part of the imagined global community involves our subjection to this order, our (re)constitution not 
primarily as national citizens but as economic subjects - productive or less so, competitive or not, winning or losing on the economic terrain" (p. 49). Gibson-Graham further suggests that this subjugation to a global (and hierarchical) order implies a loss of identity and agency, as success or failure is measured not by local criteria, but rather by this global imaginary. The Ontario provincial government (specifically through its Planning Act and Provincial Policy Statement) as well as the City of Ottawa are complicit in a global order that resubjectifies citizens of Ottawa to this order. All aspects of urban development, from urban boundary extensions to the infilling of small urban spaces with large and often luxurious developments, are linked to a capitalist system that privileges private enterprise and economic growth to create a 'city for profit' rather than for people. In the urban setting, globalizing discourses of growth construct growth as the normal progression of urban society and are measured in a parallel way to economic indicators used to assess whether or not society is 'progressing'. Whitford (2001), in a report to the Ottawa Transition Board during the 2001 amalgamation process, declares: "our quality of life is directly linked to our city's economy. Changes in our economic situation also have the potential to affect our social conditions and the environment" ( $\mathrm{p}$. 49). Whitford lists and describes economic indicators (e.g., Gross Domestic Product, airport traffic, availability of land for development, building permits) and relates these directly to the health of the economy and therefore of the city. In other words, healthy cities (similar to healthy economies) are understood implicitly as those that are growing. 
Kate states that this focus on growth seems to "directly contradict what most of the people in the various communities want to be doing" suggesting that subjection to this 'global order' does not necessarily reflect the needs and desires of urban dwellers. A number of participants share this sentiment and feel that the City is dysfunctional in the way it governs; furthermore, the City seems to have distanced itself from communitybased planning as was common in the 1970s and 80 s (resulting in such tools as neighbourhood plans):

... you know a big disconnect that we keep seeing is that you have the superorganizations like school boards and city and ... the province ... whoever it is, like levels of government that have fiduciary control, but that are disconnected from the people with the service or the facility or whatever are being provided to ... but the way that decisions are made are so disconnected from the communities that are using them, you know. And I guess the only way around that ... if you have really strong representation maybe, in those organizations, but ... you don't. And even there, it does come down to personal relationships. (Lillian, female in her 50s)

Ted, a male business owner in his $60 \mathrm{~s}$, explains the disconnect between municipal government and communities as a means through which the City conveys an image of public engagement, without incorporating meaningful consultation into the decisionmaking process. The city does this by operating under the protection of official language and procedures designed to avoid interference from, and conflict with, urban residents:

... you know I think there's a disconnect with the city ... they're going through the motions but they're not delivering. In any form of communication you have two options: either I can ... I can front-end encode it - I can talk to you in gobbledygook - and then you have to decode it, or I can back-end encode it in the sense that I give it to you in plain English. Well a lot of people ... who have businesses, families, are pre-occupied, so they need it served to them on a plate. But the city doesn't do that. I think the biggest change I've seen in the city's reaction is now we have public hearings, which are a real drag if you go there: there's talk; people go away and then they go and do what they are going to do. (Ted) 
The disconnect that Lillian is concerned with is problematic in and of itself; but Ted feels that this disconnect is deliberate: it is part of a strategy to retain control of the governance process while giving the impression of democratic engagement. Furthermore, the implication of corruption by Kate and the collusion with developers as suggested by Clayton, point to a particular kind of governance that privileges growth with little regard to how it is achieved (and more specifically, what democratic processes have to be overlooked in order to accomplish it). Kate gives a specific example of how discourses of growth (that shift the focus to economic increase rather than urban planning) have practical implications for how and where the City develops:

... our local councillor, Clive Doucet was talking about ... they took a little chunk of land that was sort of all surrounded by already built-up areas and they opened that up for development. It wasn't a huge, large chunk of land, and it was ... didn't expand the boundary ${ }^{30}$ - I forget how large it was - but, you know, and he talked about how many billions of dollars that tiny little chunk of land was worth to the developers. How many billions it would be bringing in. So it's a huge driving force out there is to ... for somebody to be making money.

In a lecture, Councillor Alex Cullen (2010, March) explains that although there are alternatives to developer-led growth (such as municipal land expropriation), the development industry has proven quite effective at lobbying municipal and provincial governments to facilitate short-term gains. Councillor Clive Doucet (in an interview) also sees this kind of growth as disconnected from what urban planning should prioritize and is centred instead on the development industry and the profits that both this industry and the City reap:

\footnotetext{
30 This expansion was 230 hectares; although the expansion area is nearly surrounded by designated urban land, it is still considered an expansion of the urban boundary (Ottawa, 2009a).
} 
The urban boundary line - we have enough space for 15 - 18 years of growth; there is no reason for us to expand it, we expanded it by 230 hectares because that's what the development industry really ... wanted ... the development industry would have taken even more of course. There's little kind of genuflections here and there to the concept of sustainability but overall, nothing of any importance happens.

Doucet points to the pressure and influence that the development industry has on municipal policy and how growth and profit are central to the creation of policy and the practical implications for land-use. Land-use decisions including changes to the urban boundary, coupled with governance changes such as amalgamation, influence how individuals, policy makers, and developers (among others) relate to their urban environment. Section 4.2 further addresses the discursive construction of urban sustainability, particularly vis-à-vis urban form, and what specific urban arrangements should be considered sustainable or unsustainable.

\subsection{Discursive Constructions of Scale}

The genealogical overview in Section 4.1 provides some insights into how dominant discourses of development, growth, and sustainability influenced urban planning in Ottawa and how scalar discourses of sustainability legitimated localized sustainability initiatives. This genealogy also highlights the dominant role of the development industry, particularly in the way that municipal policies and development practices have co-opted sustainable development to enable capitalist growth and accumulation by more and more explicitly commodifying all aspects of urban space. This commodification of urban space includes the neoliberal practice of downloading governance responsibilities to industry, in effect commodifying and privatizing 'policy space' as well as the physical urban spaces of capitalist accumulation. Despite the power of the (neoliberal) provincial 
government and the development industry, many interview participants point to the urban-rural divide, resulting primarily from amalgamation in 2001 - one embodiment of neoliberal governance - as central to how the City of Ottawa is currently governed and the confrontational atmosphere that seems to prevail. The ways in which both urban and rural are constructed have significant implications for the discursive shift from sustainability to growth.

\subsubsection{The urban as the site of sustainability.}

In an interview, Councillor Doucet engaged with an understanding of sustainability that perceives current practices of urban development as complicit in a global environmental crisis of misuse and abuse of the planet and its resources. According to Doucet, one way to achieve sustainability is to support public transit - particularly electric light rail - and to focus investment on the existing urban area by limiting growth and intensifying landuse within areas where services already exist (this process of intensification will be discussed further in Section 4.3). Doucet's view is consistent with those that create distinctions with what is considered urban and with those that see the regions outside of this urban centre not simply as suburban or rural, but as anti-urban. This view of the suburbs as anti-urban is consistent with Smart Growth and New Urbanist portrayals of the suburbs as inherently unsustainable, as this sprawling form 'consumes' valuable farmland and other 'natural' resources. According to Doucet, the current governance structure that emphasizes this urban-antiurban divide and the sprawling growth patterns that seem to be enabled by this particular governance arrangement are also problematic, particularly since suburban development is being subsidized by the central urban area 
(this argument is discussed further in Section 4.2.2). He states: "there's a very big political argument for continuing with it, because the majority of councillors, rural and suburban, benefit from that kind of growth." Thus, according to Doucet, within the current governance structure in Ottawa, the current pattern of urban development is linked neither to sustainability goals nor to economic efficiency.

Further enabling urban expansion is pressure and lobbying from the development industry, particularly from certain large developers who have for years been purchasing agricultural land in the Ottawa region - effectively speculating on land for the purposes of future development (Cullen, 2010, March). According to Hugh, a male in his 40s, this combination of development pressure and municipal policy enable the urban pattern that many find so problematic:

... Roger Greenberg [has] made a living out of buying up cornfields and turning them into rowhouses ... the policies just aren't fair in terms of ... I mean people make rational choices ... these are rational business people. If the City's policies support their developing greenfields and it's a profitable business model, they're going to do it. So why do the policies do that? Why is it something like Hunt Club Road, which is a multi, multi-million dollar piece of infrastructure, just all it does it enable ... big sprawl box stores and stuff ... how is that a good public value proposition? So, I think a lot of it, in terms of everything, from heritage conservation, to how your city ought to grow, has to be well thought through. I mean the politics of it is that, again, these outlying suburbs have the lot of votes and stuff and their councillors, you know, share the same views, and so that's where we get what we get.

Although Hugh does not blame developers like Minto (or its president, Roger Greenberg) for causing the sprawling urban form that seems to be the current trend in Ottawa, he does see this type of development and the policies that enable it, as unsustainable and unfair to those living in more central areas. Hugh traces at least part of the problem with policy development to the governance structure that gives rural and suburban councillors 
more votes than urban councillors (i.e., votes are not proportionate to population). As such, he is constructing the rural and suburban as sites of unsustainability - as forces working against the urban, where sustainability can and should occur. What counts as urban, suburban, and rural is socially constructed, as the next section will illustrate.

\subsubsection{Re-scaling the urban.}

According to Doucet (interview), sprawling suburban growth is to a large extent the result of a political structure that gives more power to those suburban and rural councillors and wards that benefit from road building and urban boundary extensions. Yet what counts as urban, suburban, and rural is produced socially and has important implications for the discursive construction of scale. The City of Ottawa is currently divided up into 23 wards (Figure 4.1). Although it is not immediately clear from this figure which of these are considered urban, suburban, or rural, 12 wards are at least partially contained inside the greenbelt, 9 are clearly outside the greenbelt, and 2 are mostly outside the greenbelt (but include portions within it). Although the original intent of the greenbelt had more to do with giving Ottawa an urban form worthy of a capital city (Fullerton, 2005; Gréber, 1950), it has evolved into, and is now often used as, a symbolic and literal boundary between the urban and rural (Ottawa, 2005a; RMOC, 1988). Although neither Figure 4.1 nor the imposed boundaries provided by the greenbelt explicitly clarifies what portions of Ottawa should be considered urban, suburban, and rural, Ottawa (2005a) does provide clear designations (Table 4.1), although some wards arguably contain portions of each type of designation (e.g., Ward 6 contains Stittsville, 


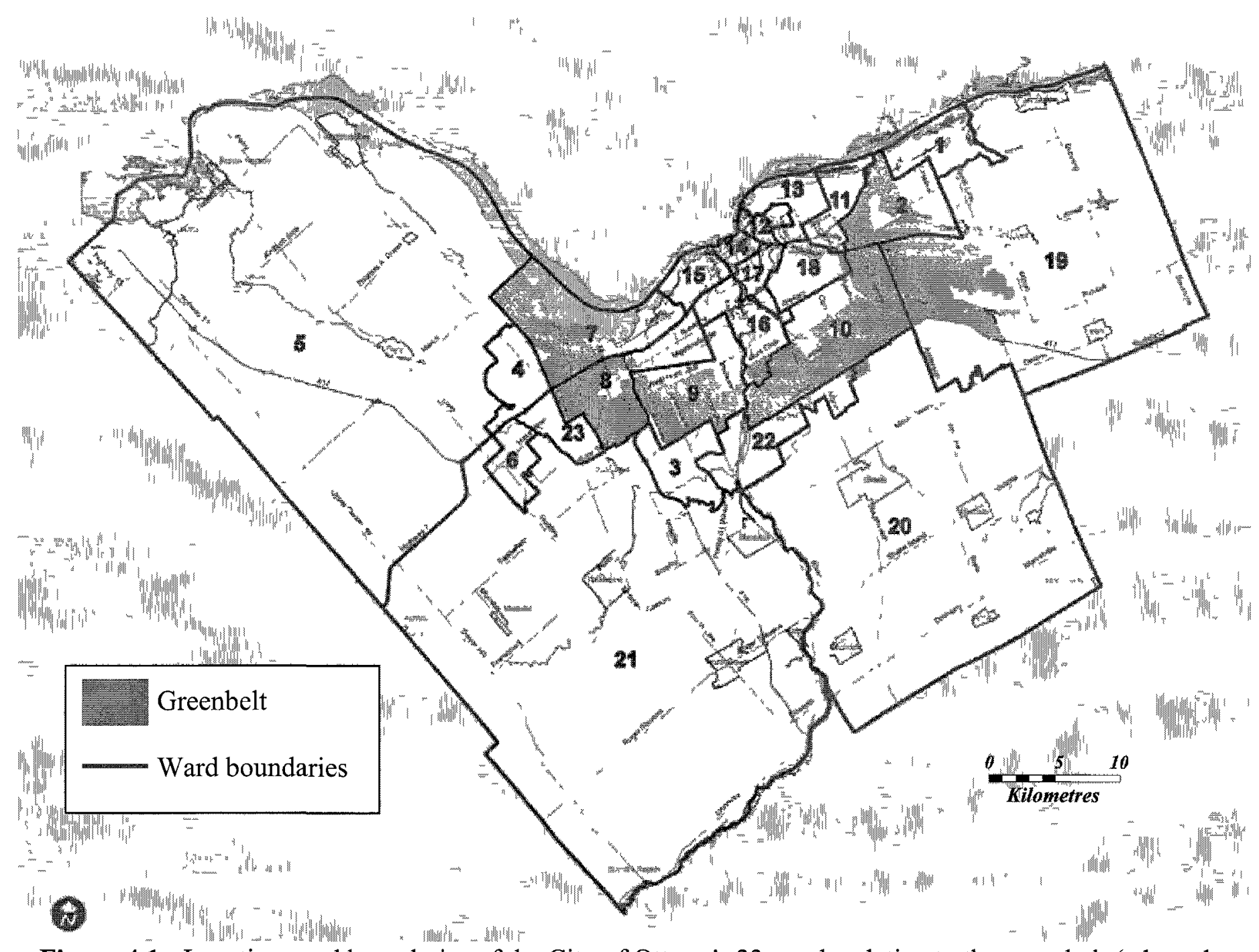

Figure 4.1: Locations and boundaries of the City of Ottawa's 23 wards relative to the greenbelt (adapted from Ottawa, 2006b). 
Table 4.1

City of Ottawa urban, suburban, and rural wards and their councillors in 2009

\begin{tabular}{lllcl}
\hline Ward & Ward Name & Councillor & $\begin{array}{c}\text { Relationship } \\
\text { to greenbelt }\end{array}$ & Designation \\
\hline 1 & Orleans & Bob Monette & O & Suburban \\
2 & Innes & Rainer Bloess & O,W & Suburban \\
3 & Barrhaven & Jan Harder & O & Suburban \\
4 & Kanata North & Marianne Wilkinson & O & Suburban \\
5 & West-Carleton-March & Eli El-Chantiry & O & Rural \\
6 & Stittsville-Kanata West & Shad Qadri & O & Suburban \\
7 & Bay & Alex Cullen & I,W & Urban \\
8 & College & Rick Chiarelli & I,W & Urban \\
9 & Knoxdale-Merivale & Gord Hunter & I,W & Urban \\
10 & Gloucester-Southgate & Diane Deans & I,W & Urban \\
11 & Beacon Hill-Cyrville & Michel Bellemare & I & Urban \\
12 & Rideau-Vanier & Georges Bedard & I & Urban \\
13 & Rideau-Rockcliffe & Jacques Legendre & I & Urban \\
14 & Somerset & Diane Holmes & I & Urban \\
15 & Kitchissippi & Christine Leadman & I & Urban \\
16 & River & Maria McRae & I & Urban \\
17 & Capital & Clive Doucet & I & Urban \\
18 & Alta Vista & Peter Hume & I & Urban \\
19 & Cumberland & Rob Jellett & O,W & Rural \\
20 & Osgoode & Doug Thompson & O* & Rural \\
21 & Rideau-Goulbourn & Glenn Brooks & O & Rural \\
22 & Gloucester-South & Steve Desroches & O,W & Suburban \\
23 & Kepean & Peggy Feltmate & O & Suburban \\
\hline & Kanata South & & & \\
\hline
\end{tabular}

Note: $\mathrm{O}, \mathrm{I}$, and $\mathrm{W}$ denote outside, inside, and within the greenbelt, respectively (adapted from Ottawa, 2009a)

* a very small portion of Ward 20 is within the greenbelt 
originally a 'rural village', and Kanata, which was developed as a suburban satellite of Ottawa; Fullerton, 2005).

Despite official designations of urban, suburban, and rural, many participants, including Councillor Doucet, discursively produce what counts (and what does not) as urban and locate the urban as the site of sustainability and the suburban as a force working against sustainability initiatives. Those areas deemed suburban are seen to require new roads and services at the expense of the central urban areas. This so-called subsidization of urban sprawl is, according to Doucet (interview), one of the biggest problems with current governance at Ottawa City Hall:

... the city is ... two and a half times bigger than it was thirty years ago. Geographically it's exploded; it's the biggest city in North America ... or in Canada, maybe one of the largest in North America in terms of geography, so the costs of putting the sewer pipes ... we now are putting fresh water out to Russell Township because the water in Russell Township is polluted - the groundwater so they want fresh city water; so when you're seeing them digging up Preston Street and taking two years, the reason they're taking two years is because they're putting in pipes that are big enough to take storms surges from Kanata ... $25 \mathrm{~km}$ of pipe, you're basically building underground rivers and little cities don't require that; so the costs of servicing that sprawl is increasing faster than our ability to pay for it and so the subsidy from the developed parts of the city is getting deeper and deeper and deeper where you ... 75\% of our transformers are over 4 decades old; they have to be replaced, so we've put off replacing them so we can subsidize electrical distribution elsewhere. We've put off replacing sewer pipes in the old city so we can build them elsewhere; we've put off repairing roads in the old city so we can build them elsewhere. So the subsidy, the costs of the subsidy to the developed parts of the city is just getting deeper and deeper and deeper and a lot of councillors can see that, you know, they can see it. They don't vote the right way, but they can sort of understand it.

The problem, according to Doucet, is that the City of Ottawa is providing more new infrastructure than it needs and this demand for new infrastructure from the suburbs not only undermines the City's ability to maintain and upgrade existing infrastructure in the 
more central parts of the city (through neglect and delays in repair), but also means that the central parts of the City pay a large portion of the cost of this infrastructure.

According to Hemson (2009), the costs associated with rural and suburban (defined in the context of this discussion as located outside the greenbelt) development are higher than the City average (15\% and $6 \%$, respectively), whereas urban development costs are $6 \%$ lower than the City average. Hugh reiterates this notion of the centre subsidizing the periphery, by arguing that city policies that allow for continued sprawl at a price that does not adequately reflect true costs are ultimately unfair to those who live in more central areas and have to put up with fewer services and older infrastructure: ... why do we subsidize ... in a city like Ottawa, the way property taxes work, I mean we pay a huge premium to live in the city centre just because the market values our land more and yet the upkeep of those older houses is quite a lot. It would be, you know, a thousand and one times I think - you know, not that I'd want to do it - but I totally understand why someone would sell a house here, you know, for half a million today and say, 'well, I'm going to go move to Riverside South and buy something for three hundred and fifty thousand. It's going to have, you know, like a dry basement; I can use the space. It's going to have modern heating and ventilation, and I'm going to have new schools, etc. I'm going to pay, you know, easily thirty percent less in property taxes'.

Hugh goes on to make connections between this subsidization of urban sprawl with policies that fail to take sustainability seriously and even do the opposite: promote and create incentives for living unsustainably. Hugh argues: "you don't have to subsidize people's choices, but you can incentivize what you want; and if you want sustainability, you've got to incentivize sustainability; but don't incentivize unsustainability." According to Hugh, discourses of growth enable unsustainability, but the City should do the reverse: penalize unsustainability and refocus efforts on making the current city more sustainable. Clayton is particularly disturbed by the lack of investment in the central 
urban area for smaller projects that for him clearly promote sustainability. The Corktown Bridge, connecting Sandy Hill to Centretown, is one such example of a project that took years to gain approval, while millions were spent for road building in the suburbs:

... what you hear up front all the time is the money argument: 'Oh we can't afford it.' Well ok, well if that's true, what are we doing building fifty million [dollar] extensions to Terry Fox and not putting it the Corktown Bridge. That doesn't make sense. That doesn't ... that belies their claim. And then not having the money? Well why don't we have the money? We don't have the money because we're spending huge gobs of money on capital ... new infrastructure out in the burbs, when we can't even fix our own ... I mean ... we creep along ... we do Bank Street in seven years or something like, gradually, and it's an embarrassment, but they ... that all needed to be done; it should have been done a long time ago; it wasn't; they're creeping along now at a snail's pace ... while they're still continuing to think huge ... you know, Strandherd Bridge, and all the things that are actually going to facilitate inefficiency: cars, in other words; not public transit. (Clayton)

For Clayton, pedestrian or public transit oriented projects are neither taken seriously nor given any type of priority compared to the perceived need for roads and bridges in the suburbs. According to Hugh, the current pattern of sprawling urban development is particularly frustrating because urban citizens financing this type of development have little control over it and are often penalized for not taking advantage of the new offering of housing choices in such places like Barrhaven and Riverside South. Hugh explains: "the way that a city like Ottawa is governed and the way amalgamation was done and worked itself out, people who have a certain perspective - certain values - can't even have their tax dollars applied to support the way in which they want to live. Again, the donut sort of votes what the hole gets." This perceived imbalance of power is a common theme among interview participants, especially those involved in contested development projects in Old Ottawa South. 
The above quotation from Hugh suggests that the perspectives and values of those

living in central areas are being ignored, largely due to the governance structure in

Ottawa. Other participants share this notion that the current governance structure gives

more power to the suburban and rural councillors than to the urban ones:

... we have this urban-rural split on council ... we're always outvoted under the present system, that unless there's some way of changing maybe the way that that's done, it just comes down to votes. There's more of them than us; so if you're living downtown ... that's part of it. You're going to have more traffic; you're going to have more intensification. (Emily)

The way that the urban is constructed in this quotation contradicts what Table 4.1

suggests: that Ottawa is composed of 12 urban wards and 11 suburban/rural wards (based largely on the placement of the greenbelt). In Old Ottawa South, many participants consider the number of urban wards and councillors to be more in the range of 6 or $7^{31}$, indicating that they have their own notions of what counts as urban and what does not:

... the balance is so out of wack, like let's say fifteen to six or something like that. Or even if it took four or five in the middle who are kind of reasonable and they' $\mathrm{d}$ kind of go either way, you're still left with an abundance of people who are living and representing people who are living in the ... hinterland if you call it ... you can see it. Look at the map of Nepean and where it extends to. And Gloucester. Huge farm fields. (Clayton)

The above quotations indicate a clear (though obviously contested) divide between urban and rural (although many other participants frame this divide as urbansuburban, and Hemson, 2009, adds a fourth category: rural village) and also redefine the neighbourhood of Old Ottawa South as a downtown neighbourhood. Referring to Figure

\footnotetext{
${ }^{31}$ The City Council voting record on the Lansdowne redevelopment proposal came to epitomize a highly polarized split on council, largely between the 'urban' and 'non-urban' councillors. On June 28, 2010, City Council voted to approve the redevelopment plan. Out of nearly 50 motions, most of the voting was polarized around a 15-9 split (Hua, 2010).
} 
4.1 , one can understand how both amalgamation and the presence of the greenbelt have influenced the discursive construction of what counts as urban and what counts, therefore, as something else - be it suburban, or rural. Putting boundaries, delineations, and classifications on a map further officializes discursive constructions of scale for fixed periods of time and effectively normalizes these constructions to the status of 'truth'.

In 1907, Ottawa South (later Old Ottawa South) was one of the newest suburbs in Ottawa; much of it was farmland up to the 1920s and the distance to downtown Ottawa was a barrier to development until the streetcar arrived in 1913 (Minton, 1972, August 5). Even in the most recent official plan (e.g., the secondary plans within the 2003 official plan; Ottawa, 2007b), the portions of the city deemed to be 'downtown' do not extend beyond Centertown. Despite this official definition, what constitutes the central urban area or the downtown core has for years been shifting; the formation of the greenbelt in 1961 (RMOC, 1988) and amalgamation in 2001 are two processes that greatly influenced the gradual rescaling of what counts as urban. All interview participants referred to Old Ottawa South as either central or downtown, indicating that they self-identify as being a part of the urban as opposed to the suburban fabric of Ottawa. This urban self-identity has important implications for how participants construct sustainability and what they deem to be appropriate 'sites' of sustainability and unsustainability.

Emily refers to downtown living as having more traffic and more intensification. The discursive rescaling of Old Ottawa South and the City of Ottawa has practical consequences and contradictions, of which many are related to land-use and development. Investment in roads to the suburbs continues to increase even as some 
councillors keep pushing for urban intensification within the central urban area; meanwhile, many residents in those areas often protest the perceived negative impacts of intensification within their neighbourhoods. Section 4.3 examines in greater detail the discursive production and practical implications of urban intensification.

\subsection{Discourses of Urban Intensification}

According to Rose (2001), based on the work of Foucault, discourse analysis can make explicit contradictions and complexities within discursive formations: "part of the power of a specific discursive formation may rest precisely on the multiplicity of different arguments that can be produced in its terms" (p. 156). Discourse analysis can reveal these dominant discourses through contradictory statements or efforts to reconcile them. As Section 4.4 illustrates, discourses of intensification are dominant not only in municipal planning documents in Ottawa, but also in Old Ottawa South. These discourses contest the terms of each other (Rose, 2001, p. 137) and are complex and filled with contradictions. They are legitimated in particular ways and privilege particular forms of knowledge in order to generate truth claims. But discourses of intensification are powerful, as Foucault would suggest, precisely for the multiplicity of different arguments that are produced in their terms.

\subsubsection{Deconstructing intensification.}

In an interview, Councillor Doucet acknowledges that intensification is a complex concept and highlights what he perceives it to mean and what the practical consequences of it should be: 
... intensification is actually a very complex concept that has got many, many different strands. One of them was we knew we had to start building our city around electrical light rail. We had a project to go down to the south end of the city all the way to Barrhaven through Riverside South; the idea was to build ... instead of creating a city around cars and freeways, the way we did in Orleans and Kanata, and in Barrhaven, to have one little section of the city to grow up around electric light rail service; and we negotiated the cheapest surface system in North America from Barrhaven to the University of Ottawa through the University of Carleton; and this Council killed it. If they understood ... if they took climate change seriously, if they took sustainability seriously, if they took the coming crisis seriously, they would have signed off on that in overwhelming majority.

City Councillor Peter Hume echoes this link between public transit and intensification in an interview with EMC News: "intensification is about applying smart growth principles to develop communities in ways that are sustainable ... giving Ottawa residents the choice to live in areas where using a car is optional because transit, cycling, pedestrian pathways and the basic necessities are just a short distance away" (EMC, 2009, December 24). These views of intensification draw to some extent on the planning models of transit oriented development (TOD), which have a number of similarities to streetcar based suburban developments of the late $19^{\text {th }}$ and early $20^{\text {th }}$ centuries, particularly in the United States (more commonly known as streetcar suburbs; see for example, Jackson, 1985; Wheeler, 2003). Transit-oriented development seeks to concentrate moderate and high density mixed-use centres around public transit nodes, such that more people have access to public transit and need not rely on personal vehicles for commuting (Ottawa, 2007b).

The principles of TOD and intensification are not new in Ottawa and can be found in Jacques Gréber's (1950) Plan for the National Capital. Gréber, a French architect and urban planner, assumed that multiple unit dwellings and apartment buildings would eventually replace many of the detached houses predominantly found in Ottawa in the 
1940s. Based on this assumption, Gréber advised the Federal Government to create a greenbelt in Ottawa (completed in 1961; RMOC, 1988) to limit further urban expansion, since, "it is thus possible to envisage the eventual population reaching without inconvenience, 600,000 within the limits of the agglomeration as defined in the plan" (Gréber, 1950, p. 191). Considering that the population of the Ottawa region ${ }^{32}$ in the 1947 census was 212,060 , Gréber assumed that by increasing urban density, Ottawa could readily bear a nearly three-fold population increase within the area defined by his plan (ibid.). Furthermore, Gréber did not preclude the possibility of developing beyond the greenbelt, but offered that this could be done in a manner similar to what would become known as TOD nodes:

Exterior to the rural greenbelt and at a sufficient distance therefrom to ensure the permanency of a rural frame to the future Capital, other nuclei of populations could be established in the rural zone in the form of complete self-contained communities comprising from 20,000 to 25,000 inhabitants, similar to the towns of Buckingham, P.Q., or Smiths Falls in Ontario. The rural regions surrounding the Capital on both sides of the Ottawa River offer excellent road and railway facilities for exploitation and favourable development of this type of 'new cities' as satellites to the Capital. (p. 191)

Unlike TOD, Gréber did not specify that these nodes need be serviced by public transit and he was particularly averse to streetcars, overhead streetcar wires, and the inconvenience of both streetcars and their tracks to automobile traffic. Gréber proposed orderly groupings of development that could be serviced by transportation arteries extending in a radial pattern out from the core. He did not specify a preference for either

\footnotetext{
${ }^{32}$ Gréber (1950) considered this region to include the City of Ottawa, the Town of Eastview (which would become Vanier), the Village of Rockcliffe Park, the Township of Nepean, the Township of Gloucester, and the Townships of Torbolton, Fitzroy, and March.
} 
automobile traffic or public transit, although he did seem to favour buses over any form of rail transit, particularly in the 'heart' of the City (Gréber, 1950, p. 223).

Intensification that occurs in a TOD model is to a large extent suburban intensification, focusing on new developments. According to Calthorpe, cited in Rees (2003), TOD is often used to structure neighbourhoods and regions, suggesting that potential sites are conceived as transit oriented before they are actually developed (although practically, many TODs are retrofits of existing areas ${ }^{33}$ ). As such, the argument that electric light rail (particularly in suburban regions such as Barrhaven and Riverside South) need be part of an intensification strategy does not address the suburban portion of TOD, as intensification calls for increased density in areas that are already built up, serviced by infrastructure, and outside the framework of suburban TOD nodes. For Gréber, intensification of the existing area should occur first; expansion into nodes (that would require transportation arteries) would occur only after the urban land capacity had been exceeded.

The argument for electric light rail posits that although sprawl is inherently unsustainable, electric light rail can somehow redeem sprawling urban form by retrofitting it with some degree of sustainability. At the same time, the demand for rapid transit service suggests that people need to be moved great distances and wish to do so more conveniently; thus TOD and light rail transit may enable sprawl in a similar way that road building purportedly does, or as Keil and Boudreau (2006) propose in a Toronto

\footnotetext{
${ }^{33}$ Ottawa (2007c) considers existing or future TOD nodes to include Tunney's Pasture, Westboro, and Billings Bridge.
} 
study, support for light rail transit to the suburbs can be "a thinly disguised attempt to create a better infrastructure for more sprawl" (p. 55). With TOD, sprawl continues to occur, although it is more 'sustainable' sprawl in that development is concentrated around mixed-use nodes, facilitating a decreased reliance on the personal automobile and thus reducing the need for new roads (Ottawa, 2007b). Although Councillor Doucet and Ottawa (2007b) link electric light rail with processes of intensification and urban sustainability, arguments supporting intensification rarely mention cars (although they do mention the costs of roads and bridges and parking space requirements). Rather, discourses of intensification, as the rest of this section illustrates, focus on built form, lifestyle, and the economic costs of sprawling infrastructure.

Discourses of sustainability that rely on planning models such as TOD privilege certain aspects of resource use and conservation: within these models, road building and single use areas (e.g., zoning that specifies residential only) are viewed as unsustainable, while mixed-use centres accessed by public transit are viewed as more sustainable. TOD does little to reconcile land-use patterns such as sprawling suburban growth but simply mitigates the effects (which are more about lifestyle than sustainability) of increased distances from the urban core to its hinterlands. Furthermore, Gunder (2006) has shown that 'nodal development' and public-transit infrastructure can often be linked to ghettoized high-density concentrations of the working poor, which are usually located far from central areas, due to the high cost of land and rent in central urban areas. Gunder (2006) uses public transit as an example of sustainability initiatives that rarely satisfy all common interests (or even environmental interests) as they are purported to do, although 
he perhaps exaggerates the ill effects of public rail transit at the expense of any benefits it would provide:

... a new sustainable rail corridor means noise, vibration, and loss of amenities for residents adjacent to the new alignment, little different than the adverse effects of a new unsustainable freeway. Similarly, high-density residential development without quality design and construction may mean low residential amenity at the level of local place, even though it goes hand in hand with the desirable ability to sustain public transit at the regional level. (p. 214)

TOD, like other sustainability initiatives, relies on 'ideological' foundations that particular constructions of sustainability are inherently and universally beneficial to the common good, that any negative effects are outweighed by the positives, and that those who cannot understand this simply need to be educated by experts. Gunder (2006) discusses the discursive production and dissemination of expert knowledge, suggesting that planning officials in Melbourne, Australia, used the structure and authority of the municipal planning department to 'educate' and change the behaviour of the community. Gunder elaborates: "some planners take the position that the ends justify the means and that they should have the right bestowed on them in the name of sustainability to impose their vision and the necessary behavioural changes to achieve such an outcome" (p. 217).

Similar to Melbourne's city planners, Alta Vista City Councillor Peter Hume has been particularly aggressive and outspoken about the need for urban intensification, even in the face of direct opposition within his own council ward. An Ottawa Citizen story provides a particularly illustrative example of his strategy to address opposition to a proposed nine-storey development in Alta Vista. Rupert (2008, October 8) quotes Hume in an explanation of how communities must be educated to understand intensification: "the challenge to municipal leaders who want to succeed in changing the face of the city 
is to show people why intensification is good ... communities will work against change if they don't see the point ... we will have to lead them through an intensification phase." Hume constructs community members not as intelligent and capable people who have their own needs and desires within the community, but as uninformed subjects, who may be capable of understanding what the City really needs, but who must be educated and led in the appropriate direction by an authoritative expert.

The reliance on scientific, expert knowledge legitimates discourses by giving them authority and rules in which to operate, and dismisses competing discourses as uninformed and incapable of accessing the truth. As such, discourses that essentialize and legitimize intensification parallel 1960s planning in Ottawa and other North American cities. Fullerton (2005) traces the history of planning in Ottawa and posits that planning after World War II relied on theories that claimed to be rational, scientific, technical, beyond the understanding of the public, and thus outside the bureaucratic constraints and obligations of public consultation. This model of planning was seriously questioned by communities in Ottawa and across Canada, such that in the 1970s, communities became involved in the process of official plan development, particularly to oppose the way urban sprawl was purportedly changing the landscape of cities for the worse (Fullerton, 2005). Secondary 'neighbourhood' plans within official plans are a direct manifestation of this public response (see for example, RMOC, 1988).

Current governance and planning in Ottawa arguably have some similarities to post-World War II planning in that discourses of intensification rely on the scientific and objective truth claims put forward and normalized by planners and politicians; in a repeat 
of 1970s municipal planning, reaction to these discursive norms has come from communities that are disproportionately affected by planning initiatives that these communities perceive to be harmful to themselves and to the environment. A recent contested infill project in Old Ottawa South illustrates this tension well. ${ }^{34}$ During a community meeting about this project, a city planner expressed what he thought an appropriate infill would be; neighbouring residents challenged the position of the city planner, speaking to the long-term and neighbourhood-altering effects and loss of greenspace such an infill would produce. The planner countered with arguments that as a city planner, he was more capable of determining the effects and appropriateness of a particular infill development on a neighbourhood than were its residents. Similarly, Finlay (2010) posits that one role of planners is to educate the public and city councillors; this role is consistent with what Peter Hume described to be his own role: to educate and convince the public on the merits of urban intensification.

Councillor Doucet also considers intensification essential, but is less convinced about the role and authority of experts. During the same community meeting mentioned above, Doucet explained that the city "does not have infill development figured out yet" but that the City's planners are improving and are trying to take a more holistic approach by using design guidelines and public consultations. He clearly realizes that such policies as intensification have been co-opted by the City and developers to maximize economic

\footnotetext{
${ }^{34}$ The meeting was held April 19, 2010, discussing the proposed redevelopment at 71 Hopewell from a single detached home into three townhouses. This development proposal was contested and several community members mobilized and publicized their opposition via a petition to City Council, an online forum on the OSCA website, and newspaper articles in The Oscar (e.g., McCoy, 2010).
} 
returns. Yet these contradictions can also be read for the ways in which Doucet attempts to reconcile intensification. In an interview, Doucet reflects upon the ways many councillors invoke intensification for the purposes of realizing development, rather than dealing with the more serious matters of climate change and environmental degradation. In the following statement, Doucet responds to my questions about how the redevelopment of 88 Bellwood from a school into townhouses achieved the goals of intensification:

... for the city, intensification is ... and most of my colleagues ... its all about getting more tax revenue out of the same parcel of land. That's what intensification is ... it's tax dollar per unit of land. Those units are now returning thousands and thousands of dollars in taxes, which is gonna ... pay for the water, pay for the electricity, pay for the sewer, pay for the police services, pay for the paramedics. So, it's - as I said at the very beginning - that's the number one criteria. So when the city says 'intensification', that's what they mean. They don't mean more schools. They don't mean more greenspace. They don't mean more ... they mean are they getting more money, more tax revenue to service the same amount of land ... that's the measure.

The 2003 official plan privileges technical interpretations of intensification, such as density requirements (approximately 72 residential units per hectare in neighbourhoods such as OOS; Ottawa, 2005c). According to Doucet (cited in Cummer, 2002), these officialized constructions of intensification are missing an important component, "[a]s we intensify use of land in all inner city neighbourhoods ... it becomes more important than ever to retain non-renewable public spaces such as parks, greenspaces, schools and public amenities such as day cares and not-for-profit organizations" (p.5). Furthermore, Doucet (interview) implies that not only is the policy of intensification largely an economic strategy of increasing the tax base without having to increase the infrastructure (including 
these community 'amenities'), but it is also the main practical manifestation of urban sustainability policy in Ottawa:

... sustainability is largely about intensification, which is largely about ... creating a city that costs you less to service so you can reduce your tax base; it's not an integrative emergency where you're retrofitting your city at light speed to get ready for the onslaught of a very different world.

According to Doucet, when the City refers to intensification, it is talking about increased intensity of taxable land-use, not the addition of parks or other community amenities that may draw a population to a particular location and provide use value to the local population. This oversight can be interpreted as a practical manifestation of the changing purpose of the official plan, especially the most recent one (from 2003), which has completely removed non land-use planning issues from its charge. The remaining policy tools, such as Ottawa 20/20, fail to adequately address intensification in terms of the nonland-use planning repercussions that it may have - to be discussed further in Section 4.5.

Doucet's statement about what his priorities for intensification are - an integrative emergency where you're retrofitting your city at light speed to get ready for the onslaught of a very different world - are consistent with scalar discourses of sustainability that draw on calls to action from United Nations declarations, such as the Brundtland Report and Local Agenda 21. When Doucet uses the language "onslaught of a very different world," he is not referring to highly localized environmental or societal issues such as traffic, smog, or loss of farmland. He is referring to multiple, emerging and converging global issues of climate change, peak oil, and widespread environmental degradation. As such, Doucet is mobilizing scalar discourses of sustainability that recognize cities as local sites of sustainability initiatives that can contribute to solving a global problem. The vertical 
nature of this scalar discourse is evident as the authority of international bodies (mostly affiliated with the United Nations) dedicated to global environmental crises legitimizes this discursive construction of sustainability by calling on cities worldwide to make sustainable development a priority within their local government policies. Local Agenda 21 action plans are one such example of an authoritative United Nations organization calling on local governments to develop their own unique strategies for sustainable development (UNCED, 1993).

Darryl engages with the concept of scale, not as a vertically arranged hierarchical structure, but rather as something that starts small but then spreads outward in a horizontal fashion: "the way isn't ... to make it big. The way is to make it small, but in order to make it small and make it work, you have to affect a larger ... a larger arena, a larger sphere of influence." This horizontality is largely absent within scalar discourses of sustainability, although such community-level organizations as the Federation of Citizens' Associations of Ottawa-Carleton (known simply as the FCA) and neighbourhood community associations do exist and often influence official plan policies (Fullerton, 2005). The FCA is composed of representatives from community associations in Ottawa and is involved in providing input during official plan reviews, among other things (Fullerton, 2005). However, policies such as intensification seem to be hierarchical, originating with global call for cities to become more compact and efficient, and culminating in provincial policy statements that require municipalities to adopt intensification targets within their official plans. 
Agenda 21 and many provincial governments consider sustainability to be a global movement with local responsibilities. If this is the case, the City of Ottawa is notably irresponsible. The vertical scalar structure described by such efforts as Local Agenda 21 breaks down when council fails to take sustainability seriously, as Doucet suggests. Furthermore, when initiatives like intensification are vertically imposed, legislated, and made official, they can become what Gunder (2006) refers to as a "resource, or tactic, capable of co-option" (p. 213). Political and economic actors can manoeuvre the sustainable development discourse to further their own ends, rather than to achieve specific sustainability goals. The scalar purpose of sustainability initiatives is thus lost or diluted, as political actors use it for their own purposes rather than for those deemed important by global discourses. Hugh reiterates this sense that Ottawa lacks genuine commitment to sustainability, while other cities and provinces have made progress towards sustainability:

... you know even when we get something here, even when we make progress here, it's - in Ottawa - it's ... it's not even sustainable. Like, when they redid Bank Street here, there were streetscaping elements and boulevards and plantings and stuff put in - no budget though to sustain them. Vancouver ... in Vancouver they water the flowers. In Vancouver they have an elected parks board. They take care of their public spaces. And this city and Vancouver has a different governance structure. There's an act pertaining to ... Vancouver Provincial Act, and in terms of the funding and the resources it has, it just works better. The city government is on a party system. So the councillors who get in, at least there's a shared value and platforms and stuff. You may not necessarily agree with it but at least there's a sort of sense that, you know, the people voted in a certain way and that's the direction the city is headed in. Whereas here, it's just these ... it tend to be these small little fiefdoms.

According to Hugh, politics more than planning has determined the way Ottawa engages with sustainability strategies like intensification; he suggests that a more holistic policy of 
intensification could have helped the school at 88 Bellwood remain viable. In doing so, he also tries to reconcile contradictions within discourses of intensification by proposing what is wrong with the school boards in Ottawa and current sprawling development and how it should be done - how intensification (or densification) can work:

... had you had another smaller school here as an alternative, it would have taken some of the pressure off of Hopewell, and it also would have, you know, leveraged the City's policy of densification. If the City wants people to live in inner city neighbourhoods and something, you've gotta have, not just schools for kids, but spaces for after school stuff: gymnasiums and stuff - meeting space. And none of that fits the Catholic School Board ... vision of what their mandate and their role is $\ldots$ and the whole thing about if you go through the restructuring of the Catholic School Board, it's like the City itself. Increasingly it's like a donut. And the ring around the donut ... has a bigger population and more representatives than the centre of it.

Hugh further explains how the City uses intensification as a 'quick and dirty' solution without a careful analysis of what it should do; one result is that developers, who have adequate resources to negotiate and contest zoning restrictions, can use the intensification argument to get what they want:

... the problem with densification is the City doesn't do enough to kind of give it a real meaning. And you do that doing community design plans and stuff, where it's understood: this is what densification means. What we get in Ottawa, is we get developers cherry-picking. And they come in and they, you know ... an area of Centretown, and it's zoned for twelve storeys or eight storeys, they say, 'oh, how about twenty-four?' 'cause it's in keeping with the official plan and densification. No. Look, if there's nothing on that lot right now, you know ... if you put a two storey building on it, it's densification, compared to what's there now. So don't come in and tell me you have to build it in a certain way.

Discursive constructions of sustainability and intensification often implicate developers as being the beneficiaries of misguided municipal policies that enable them to build whatever they can to maximize profits. In an analysis of urban intensification in 
Toronto, Bunce (2004) notes that private investment is central to urban planning strategies that privilege economic growth; capitalist growth and environmental protection are reworked to be understood as compatible and complementary. Bunce further proposes, "the vision of intensification in the Official Plan is the primary strategy used to justify and support a market-driven economic and physical revitalization plan of Toronto's central city" (p. 180). In Ottawa, there is little evidence to suggest that there are deliberate attempts to revitalize the central city, although Ottawa, as the national capital, has different constraints than does Toronto. However, as illustrated by the contestation of development projects, official plan policies enable particular types of developments that seem to conflict with communities that have to live with them. Intensification relies on discourses of growth that privilege and essentialize increases in density and residential housing units at the expense of other ways of perceiving and achieving sustainability; furthermore, intensification is empowered by the same policies and pro-development initiatives that undermine intensification by expanding the road system (Ottawa, 2010b) even while calling for increased density in central urban areas.

Despite the involvement of community organizations and such policy tools as community design plans (CDPs), the role of developers seems to be more important to the municipal goals of intensification than do sustainability, community engagement, and democratic processes. In an interview with Maria Cook from the Ottawa Citizen (2008, October 27), in reference to the redevelopment of 35 Brighton, Doucet notes the current tensions between municipal policy and community engagement: 
... there is no law that says you can't build a monster home. Currently, the term 'intensification' is not much more than a licence for spot rezoning. Community design plans will become an important tool for controlling esthetics [sic], size and height. They are a detailed response to the Official Plan's requirements for intensification. The community is going to be exercising much more control over the landscape. We're hoping it [Community Design Plan] will become the vehicle that will bring quality control to intensification ... [however] the city doesn't want this to happen. In Ottawa East, the city doesn't want to see main streets limited to four or five storeys. There's a power struggle going on.

When the 'monster' homes to which Doucet is referring are built on relatively small lots, they usually approach the maximum build out permitted within the zoning. This type of construction can be described as an 'intensive' use of the lot and this is indeed one definition of intensification: development that increases the amount of taxable investment in a given area (Campsie, 1995). Portraying such buildings as 'luxurious' and 'sustainable' can further serve to legitimate this type of intensification discourse and give potential buyers the satisfaction that they can have both a luxurious and sustainable home in a central urban area (itself a purported contribution to sustainable urbanism).

In the case of 35 Brighton (which became 35 and 37 Brighton), sustainability is invoked by the proximity of this development to 'nature' and by the development's 'Energy Star' rating (Campanale, 2009). The Campanale website (2008) contains as many photos of this 'nature' (Brighton Beach across the street) as it does the building itself (Figure 4.2), although ironically, as a maximum build out, there is little room for greenspace on the property itself. Caroline, a business owner in her early $50 \mathrm{~s}$, expressed 

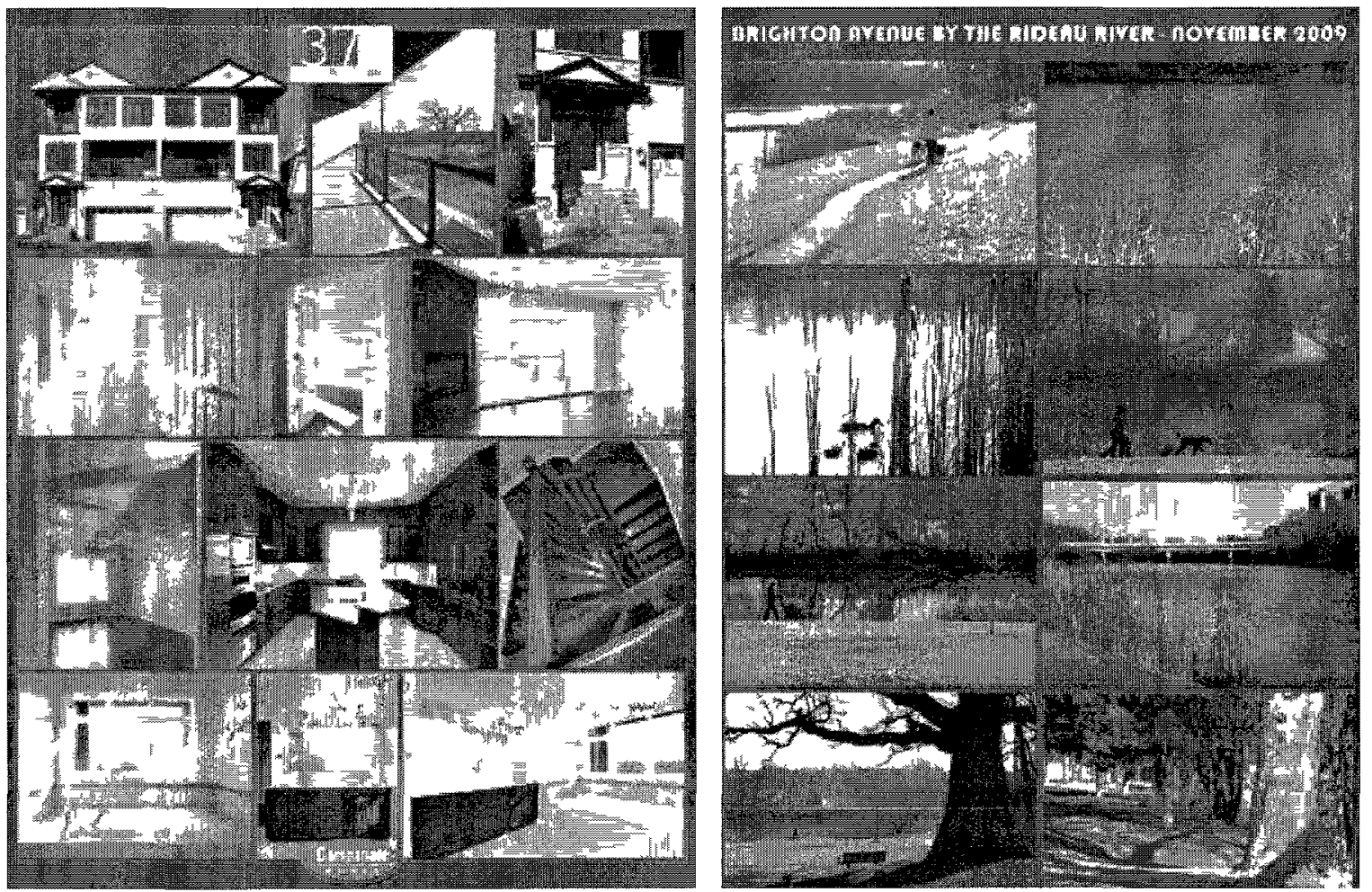

Figure 4.2: Campanale Homes' website advertısement of 35 and 37 Brighton Avenue. The image on the left portrays the 'luxurıous' features of the home, including a large garage and 'gourmet kitchen' (Campanale, 2009). The image on the right shows the 'nature' directly across the street from this development: the Rideau River and Brighton Beach Park. (Source: Campanale Homes, 2008). 
frustration at the way in which developers use sustainability to take advantage of the neighbourhood:

... we are going to do maximum build out and we really like living in a neighbourhood of trees but we want you to have the trees on your property. We don't want the trees on our property ... and that's what really drives me crazy, is, it takes advantage of the neighbourhood ... and then, it's even advertised that way ... 'we're going to take advantage of this really nice leafy neighbourhood but god almighty we're not going to give up an extra bathroom ... to have a tree'. And, they argue for sustainability ... it's energy-efficient. It's this, that, and the other thing, you know. That's why I'm ... getting to HATE the term 'sustainable'.

Similarly, Cullen (2010, March) sees maximum build out as developers taking advantage of zoning, by using these bylaws to get what they want rather than what might be best for neighbourhoods. This argument could be applied to the 35 Brighton development in that no zoning variances were required to replace the small bungalow with two large semi-detached homes (Cook, 2008, October 27). In other words, the current zoning allows for maximum build out, but when this occurs, the resulting structures are perceived to be out of scale and detrimental to the character of the neighbourhood (see for example, Ostling, 2008a).

In a planning workshop offered by the City of Ottawa, Carol Ruddy (2010), an urban planner for the City of Ottawa, explained that zoning is 'black and white' and cannot account for the particular requirements of every land user in the city. Broad landuse zones are developed by the City in order to create order and uniform land-use areas; the result is that not every zoning configuration is necessarily suitable for particular areas, but it is difficult to identify the myriad possible configurations unless there is a proposed redevelopment or a change in use (ibid.). Councillor Cullen (interview) implies that 
developers may be well aware that certain types of developments are not suitable for an area, or that particular developments will not garner local support. However, with the backing of zoning bylaws for those properties to which a proposed development conforms, and within discourses of intensification legitimated and authorized by official plans and the $\mathrm{OMB}$, developers can be confident that their proposals can be realized whenever development opportunities arise.

Some business owners in Old Ottawa South are similarly frustrated by zoning bylaws that restrict possibilities within a neighbourhood for many (i.e., small, independent) businesses, although those with 'deep pockets' - like Shoppers Drug Mart can afford to do whatever it takes to redevelop if profits can be realized somewhere:

... bigger people with larger resources, like Shoppers, are not so dependent on this neighbourhood to make their living. They make money elsewhere - make an investment here and hope you make some cash off of it and they ... and the zoning: they can afford to look at this and say, 'ok, the zoning is not entirely the way we like it, but we can work with that.' (Kate)

Shoppers Drug Mart faced several hurdles attempting to build in Old Ottawa South, and the costs associated with their proposed redevelopment are surely out of reach for small developers or land owners. Not only did Shoppers Drug Mart have to bear the costs of environmental remediation due to historic use of the site as gas stations (an important issue but beyond the scope of this paper) but they also had to carry out traffic, stormwater and service studies, two phases of environmental site assessments, various revisions of site plans, and a whole series of community consultations (Ottawa, 2008b). Clearly, a small property owner cannot easily commit to this scale of investment, and according to Kate, even the minimum investment for a zoning change can be a barrier: 
... I called up to find out what the possibilities are for changing zoning here ... first of all, the application fee is eleven and a half thousand dollars. Do you think I have eleven and a half thousand dollars sitting in my bank account, which I can afford to lose? ... so a zoning is a kind of barrier to some people and to other people it's still a barrier, but not as much of a barrier because they have the resources and they figure that in the long run, you know, they can deal with it. And they can afford to do so. So zoning: is it a help or a hindrance? Depends on who you are. It's certainly a hindrance to some people sometime, and generally speaking, the smaller ones, who ... who are living on the margin already.

Because zoning bylaws are 'black and white', but at the same time cannot possibly anticipate every potential use, application of these bylaws must allow for some flexibility (Ruddy, 2010). Zoning is an approach to planning that attempts to create uniformity of land-use for certain areas, but in a broad way that leaves room for flexibility and negotiation. But for whom are the bylaws flexible? Perhaps for large developers; perhaps within the scope of a CDP, if a community is in the privileged position of being granted one by the City. For individual property and business owners, the planning rationale of uniform area zoning can amount to impenetrable barriers to trying to achieve their needs and desires in a neighbourhood. Kate cannot imagine a solution to the restrictions that zoning creates, especially not in a large amalgamated city like Ottawa that has moved away from smaller planning units:

... I don't know how far along they ever get along the lines of central planning. It's not an easy thing for them to do. But they're always dealing with almost crises, or zoning applications, or somebody wants to do such and so here and somebody else wants to do such as so somewhere else. And so it's piecemeal at their end as well, not because they want it to be that way, but because people outside have a need to get approval for something they want to do ... and so they have to deal with this one discrete application of whatever it is and they don't have the luxury to say 'well, let's look at the picture as a whole', 'cause they're not dealing with the picture as a whole, 'cause they can't. 
According to Clayton, even when communities are involved in the zoning development process, spot rezoning still occurs, in some cases negating the work of the community association and going against the desires of the community based on what they envision for it. Clayton summarizes: "it's a rules based society - that's what we live in. That's why getting the zoning changed was so important. The first real test: 'Ah, sure, we'll go from six hundred to eleven hundred, no problem'." ${ }^{35}$ This change in zoning refers to an urban design and zoning study (Ottawa, 2003b) that involved members of the community and City staff, and resulted in changes to the zoning on Bank Street that, among other things, specifies maximum retail space to keep large format 'big box' stores off Bank Street, in order to encourage local and pedestrian-oriented retail. According to Ottawa (2003b),

... traditional commercial areas such as Bank Street were originally built when stores and offices were smaller, whereas the trend today is for much larger-scale businesses ... the size of these uses is a potential concern given the vision for the street, which is to encourage small-scale commercial development ... if land assembly were to occur, the establishment of large retail stores or retail food stores is possible ... the main concern is that larger scale businesses do tend to generate higher volumes of traffic and require larger parking areas. (p. 45)

Shoppers Drug Mart was one of the first proposed (and eventually approved) developments to test the authority of this zoning. The City of Ottawa did change the zoning and allowed Shoppers Drug Mart to build a retail store nearly twice as big as the zoning allowed, largely due to the addition of a second storey that made it more compatible with 'traditional main street' requirements (Ottawa, 2006a; Ottawa, 2009b). Thus, for many community residents, especially those involved in the Bank Street zoning

\footnotetext{
${ }^{35}$ These numbers refer to the allowable retail area per business, in square meters.
} 
study, zoning may indeed be flexible but not necessarily to the needs of the community. More obvious are the connections between zoning flexibility, intensification goals of the official plan, and the enabling of urban development.

\subsubsection{Legitimizing intensification.}

Despite the complexities and contradictions of the intensification discourse, it has nevertheless become normalized in Old Ottawa South, although not without competing discourses. Inappropriate applications of intensification are used as foils for those examples that 'get it right'. For as Hugh maintains: "in principle I think you absolutely need it because you can't support ... all the other things that makes a community sustainable, like having a grocery store, a hardware store, a drug store, schools." For Hugh, intensification is an urban process that, although not always executed properly, is itself an essential component to sustainable urbanism. For others, intensification is something that is clearly necessary in neighbourhoods like Old Ottawa South, and the only real problem is that at times infill doesn't fit well within a neighbourhood. In an interview with Maria Cook of the Ottawa Citizen, Kevin Harper, then chair of OSWatch, states that Old Ottawa South knows that intensification is a positive step for the community:

It's an intelligent neighbourhood and we're aware that Ottawa needs to grow in, not sprawl out ... [t] here are some who don't even own cars. They're green and they know intensification is important, but it has to happen in the right way ... pretty much every double lot in Old Ottawa South is being snapped up and what's on it is being torn down and replaced by two or three or four homes... that's fine, but it has to be done right. (cited in Cook, 2008, June 23) 
Intensification discourses are legitimated by a particular construction of urban sustainability. Often cited (and present in the above statements) are the notions of compact form, mixed use, and use of public transit rather than automobiles. At least three participants referenced the writings of Jane Jacobs when discussing what a sustainable city should look like. ${ }^{36}$ Very few participants strayed far from the notion that in order to have a sustainable community, it has to be compact, pedestrian and publictransit oriented, serviced by a variety of amenities within walking distance, and hopefully include at least some 'nature'. One planning strategy that fits within these descriptions, and is itself seemingly influenced by the writings of Jane Jacobs, is Smart Growth.

\subsubsection{Is intensification a smart way to grow?}

According to Kevin Harper in the above quotation from Cook (2008, June 23), there seems to be a relationship between the intelligence of a neighbourhood and the purported need to 'grow in', not out (i.e., it should be obvious to an intelligent person that intensification is a good thing). A focus on intelligence is perhaps not the intent of this quotation, but it has its effects: (re)framing sustainability and intensification as 'smart' implies a normative component that empowers rather than diminishes sustainability discourses - intensification is normalized and need not be questioned further. Similarly, according to Peter Hume, when people are educated on urban planning issues and

\footnotetext{
${ }^{36}$ These participants were likely influenced by Jacob's (1961) The Death and Life of Great American Cities, particularly the introduction, where Jacobs criticizes city planning from the first half of the twentieth century. Interestingly, Jacobs wrote, to a large extent, about her experiences in central parts of large American cities like New York, Boston, Philadelphia, and Baltimore. Although she acknowledges that some of her ideas may have broader significance, she adds this disclaimer: "... I hope no reader will try to transfer my observations into guides as to what goes on in towns, or little cities, or in suburbs which still are suburban. Towns, suburbs and even little cities are totally different organisms from great cities" (p.16).
} 
become more knowledgeable about the problems that cities face, they can then understand that urban intensification is a good thing (Rupert, 2008, October 8). In her work in Toronto, Bunce (2004) explains how 'sprawl versus intensification' has become a binary in the public discourse, where sprawl is associated with unsustainable urbanism and intensification its logical solution. Furthermore, "[t]he development of a 'sprawl or intensification' argument also closes a space for public critique of urban intensification" (Bunce, 2004, p. 183). There is no longer a need to further discuss intensification, as the debate has been settled; furthermore, any criticism of intensification is portrayed (and thus dismissed) as insensitivity to environmental concerns.

According to Foucault, subject positions are produced by discourses that discipline them to accept certain things as normal and to act accordingly in specific ways (Rose, 2001). As discussed in earlier sections of this thesis, power is everywhere; through the operation of power, discourses are strengthened, stabilized, and some become dominant (Rose, 2001). But not everyone thinks that urban intensification is a good thing (as is discussed further in Section 4.4.4): power and discourses are always resisted at some level; even dominant discourses are continually being contested by any number of other discursive notions of what should be considered normal and the 'common sense' way of doing things.

The emergence of Smart Growth in the 1990s signalled a re-engagement with earlier theories of urban planning, such as New Urbanism (Grant, 2006a; Wheeler, 2003) and perhaps the City Beautiful movement to some extent (Grant, 2006a), to empower discursive constructions of urban sustainability and intensification. Broadly, Smart 
Growth is a reaction to sprawling, low-density urban form reliant on the automobile that seeks to replace this urban form with compact, walkable, mixed-use, and transit-oriented development (Filion, 2003; Tomalty \& Alexander, 2005; Wheeler, 2003). Filion (2003) also suggests that the origin of Smart Growth in the early 1990s was partially a response to the 'no-growth' movement in California, where growth was increasingly being associated with higher costs and decreased quality of life. Smart Growth re-engages with discourses of growth, but does so in a particular way - one that lends itself to popularity and entrance into mainstream urban planning: "it does not aim at halting, or even slowing down, growth. It rather purports to alleviate its adverse consequences so as to enhance its environmental and financial acceptability, while raising its appeal from a quality of life perspective" (Filion, 2003, p. 51). Smart Growth legitimates growth, by offering the possibility that growth can be acceptable (and sustainable) to everyone.

Wellar (2001, June 15) is particularly critical of Smart Growth, arguing that politicians, developers, and other business interests use Smart Growth to sell the idea of growth, legitimate outrageous growth by making it seem relatively 'smart', and then reframe this type of growth as sustainability: "smart is a relative term, and can be manipulated ... Ottawa could grow big-time by rezoning 25 per cent of its remaining agricultural land for strip malls and parking lots, or it could rezone all the agricultural land for those purposes. The first proposal, while patently foolish, could be rated as smart, relatively speaking, because the second proposal is beyond mind-boggling by comparison" (p. 1). Wellar further argues that Smart Growth cannot be reconciled with 
sustainability if Smart Growth is based on a presumption of growth: "sustainable development does not begin with that premise. Rather, growth or not growth are matters of choice, and ecological, social, financial, and other tests of sustainability are then applied to both the growth and not-growth options" (p.1). Thus, Weller suggests that Smart Growth empowers and reconciles discursive constructions of sustainability and growth, even though sustainability and growth are often incompatible.

Although the principles of Smart Growth have been succinctly compiled and officialized as an influential planning tool (recall Appendix A), they are evident in official plans that predate Smart Growth, particularly the 1991 City of Ottawa Official Plan (Appendix C). Recall that Ottawa (1991a) was Ottawa's first official plan to use 'sustainable development' as its mission statement and was highly influenced by the Brundtland Report. As a globalizing force, Smart Growth works in similar ways to the Brundtland Report, by mobilizing a 'globalizing imaginary' that empowers discourses of sustainability and contributes to their stability at a global scale. Furthermore, the City of Ottawa used the Smart Growth Summit in 2001 as a guiding influence for the development of Ottawa 20/20 and the 2003 City of Ottawa Official Plan (Ottawa, 2003a).

According to Tregoning, Agyeman, and Shenot (2002), Smart Growth shifts the focus of sustainability "from self-sacrifice to self-interest" (p. 342). By doing so, Tregoning et al. (2002) suggest that the debate over sprawl now includes a broader audience from a wider variety of groups including farmers, developers, environmentalists, and politicians; the result is that Smart Growth has 'gone global' by 
influencing international initiatives such as Local Agenda 21 and by appealing to a wide variety of local movements that use Smart Growth to foster local growth management plans. According to Tregoning et al. (2002), Smart Growth still faces challenges from 'NIMBY' (not in my backyard) groups and public attitudes that revolve around car culture, and what the movement needs is more advocacy and action from policy-makers and lobbyists to push for high-density development and increased public transit ridership. This position is similar to the discursive construction of intensification discussed in the last section, where politicians and planners are charged with the task of educating the uninformed masses and using such 'common-sense' 'ideology' as intensification and TOD to realize sustainable urbanism.

\subsubsection{The role of NIMBYism.}

Discourses of intensification and Smart Growth rely on global discourses that place cities as the practical sites of sustainability initiatives. Against these initiatives, those individuals who live within neighbourhoods where intensification occurs often contest such things as loss of greenspace and community space and a decrease in quality of life (see for example, Cook, 2008, June 23; Kealey, 2005; Rupert, 2008, October 8). Development proponents often dismiss this local opposition by constructing it as NIMBY. Accusations of NIMBY emerged in each contested development project upon which this thesis draws and are central to arguments that try to dismiss the concerns of groups whose lives will be affected most by incoming development projects. Even within the academic literature, NIMBY opposition is often explained as self-interested, 
intolerant, and shortsighted, and as such dismissible (McClymont \& O'Hare, 2008). Against this, a more critical research literature finds that many 'NIMBY objectors' understand their opposition as contributing to a greater good, framing protest as active citizenship towards a more appropriate and sustainable development (ibid.). Explaining NIMBY as a binary (active/selfish, preservationist/progressive) fails to account for the specificity of objections that many NIMBY arguments comprise and normalizes their dismissal within the consultative process that developers and politicians must undertake.

Although NIMBY has become a derogatory term, most interview participants construct it as a positive concept, while recognizing that self-interest can also be influential to processes of contestation:

... I'd have to say that NIMBY's probably a good thing. I surprise myself hearing myself say that 'cause ... 'cause it is often a disparaging comment ... all of us try to do what's best for the people who are closest to us: you know, our families, our neighbours ... the saving grace is that we can negotiate the mitigation factors ... there's going to be an impact on the quality of life in your neighbourhood if you've got a train going through every fifteen minutes. How can we turn around and make it so that there is net gain to the community? You don't get that if you don't have a NIMBY attitude. (Kurt)

According to Kurt, a more useful construction of NIMBY is as a legitimate mechanism by which communities can protect themselves and as a necessary means to ensure that developments accommodate the needs of those living closest to them. Caroline reflects upon the redevelopment at 88 Bellwood: "the people most affected by it rightly felt that they should have ... that their voice should be a bit ... heard a bit more clearly." In this context is it difficult to justify developments that purport to achieve sustainability goals if they negatively impact those closest to it. 
Some participants admit that NIMBY is indeed about self-interest, but they assert

that there are broader implications than simply selfishness:

... I don't think there's any way to get rid of self-interest. I think it's convincing the community that it's in everyone's self-interest to ultimately, in the longer view, it's better to do this. I don't think you can get altruism ... ultimately, it's about selfinterest. My interest in my community ... my interest in the sustainability, the issue of trees and porches and everything, is I really think it is a really good place to ... it's a really nice way to live. (Caroline)

Yet some participants cite examples where a more negative form of selfish NIMBYism

did come into play during redevelopments. Caroline recalls attending a public meeting

about 88 Bellwood, where some of the motivations for redeveloping the school into

townhouses became clear to her:

... what I recall ... there were two perspectives on things, and the one that really disappointed me was the fact that there was NIMBYism in the sense of what they really didn't want, was they didn't want any public uses. That surprised me; I wasn't prepared for that. I was prepared for them caring about the design of whatever went in there, but it never occurred to me until I went to that meeting that the fight was really about ... 'we don't want a ballet school here because people will be dropping their kids off on Saturdays, so we don't want that' so there's ... once it became clear that there was no public use for that site ... I definitely threw up my hands and said I didn't really care anymore what happened to it. Because I always imagined that they would have wanted a public use and ... funny enough, I think it was a really important part of my professional career too, to see that ... people were so focussed on the impact on their own ... what they perceived to be the impact on their own property values, that it didn't matter whatsoever what was better for the community ... I don't even think they would have been happy ... they would have been happy with a very passive park, but they wouldn't have been ... happy, I don't think, with what I would consider a public park, which is a park with washrooms and programming in it.

According to Caroline, local opposition to development (or preservation in the case of 88

Bellwood) can be, but is not always, NIMBYism (constructed as self-interested, shortsighted, and intolerant). One needs a nuanced and deeper understanding of the issues and arguments surrounding a development in order to access the validity of opposition. 
Irene, a female business owner in her 40s, suggests that NIMBY opposition could be tempered by more discussion and engagement with alternative possibilities. She suggests that citizens could be proactive and positively engaged, rather than reactionary and negative:

... instead of us always gathering at these meetings to say what we don't want - and we spend a lot of time at that - maybe we could have more meetings in the same ... I mean this goes back to what you were saying, you know, 'hey, what do we want?' ... it's like an ongoing conversation, and then maybe our councillors would sort of have a better ... maybe we could get more people to come to the meetings, if they were told, 'hey, come to the meeting. We're going to talk about what we want.'

This type of engagement, according to Irene, suggests a longer term and more meaningful dialogue with city council and property developers, which could facilitate more effective activism than seems to currently be the norm in communities. Irene also cautions that objectors have to ensure they are informed about a project before contesting it: "how do you know when you're fighting against something, that maybe it actually is going to be better for the neighbourhood? It's like, 'why are you resisting?' And that's the ... that's the million-dollar question." Similarly, Hugh, based on his experience with the community association, cites the importance of having all the information before objecting to something and to evaluate carefully the motives for protesting a development in the neighbourhood that other community members might support. He argues that NIMBY concerns can be valid but they must be based on credible information and accompanied by involvement in the process. He gives examples where the community association worked hard to influence a development process only to have the proposal opposed without specific or legitimate reasons: 
... what's your level of participation in the decision and how much information do you have? ... some people are just completely unreasonable. So there's people at extremes who just, 'oh, we don't want that, we don't like it', or this or that or whatever. I'm, well: 'change is going to happen', and so all you can do is say, 'how can we - how can we channel it' and that; and I think that having the engagement of people in your neighbourhood and having them involved in the decision-making is really, really important, but it has to be responsible as well ... it's irresponsible to say 'well, we're - I'm opposed to this, that or whatever' ... what are your reasons? And can they be addressed? ... people are always going to want to ... have some sort of say in decisions that they think are going to negatively affect them.

Hugh goes on to suggest some ways that community engagement can be less adversarial and he thinks there is more the City of Ottawa could do to facilitate community-based decision-making. According to Hugh, the way that planning and zoning currently operates leads to conflict with developers and community citizens that could be avoided if community members were involved earlier in the process and in a more meaningful way:

But, in some instances, if it's part of ... you know, if it's part of a plan that has been developed with a lot of consultation, a lot of information, a lot of understanding of the best principles and practices and stuff, then, you know, I ... a city has to take leadership, and I think you will get less of that ... I mean Ottawa's problem is that they do planning so badly here. We have a lot of, you know, spot zoning and that, where, you know ... so this person gets four storeys and the person next door: they get fifteen. You have to develop ... and say, 'look, this is the plan for this neighbourhood and this is what the density's going to be.'

The ongoing challenge for the City of Ottawa is to reconcile the needs and desires of residents who have to live with the negative consequences of policies - based largely on Smart Growth - such as intensification. In the above quotations, both Irene and Hugh point to the atmosphere of conflict that leads to resistance; this resistance is often labelled as NIMBY. For Irene, resistance is important, but should not always be negative - it would be more effective as a negotiation. For Hugh, resistance must be accompanied by 
meaningful action, rather than passive observation. However resistance is exercised, both of these participants allude to an important element that instigates resistance in the first place: power. In the context of urban development, this thesis has attempted to trace the historical development of hegemonic discourses of sustainability and growth that seem incongruous with community needs and desires. The next section addresses the exercises of power flowing from these hegemonic discourses, followed by a glimpse into the possible avenues that individuals and collectives can discover and create to negotiate and contest where necessary these powerful hegemonic discourses.

\subsubsection{The power of 'development'.}

In his work in Australia, Gunder (2006) proposes that urban planners often co-opt sustainability and use it to support policies of growth:

... sustainability can be and often has been deployed selectively by planners or politicians as a materialization of dominant institutional ideologies supportive of growth and capital accumulation ... [t]hese are promarket interpretations of sustainable development that water down the concept of sustainability to literally that of business as usual, with, at best, an objective to partially reduce urbanconsumer energy consumption and waste outputs while still maximizing the potential for all-embracing economic growth. (p. 209)

For Escobar (1996), the problems with sustainable development run deeper than simply the political and practical manipulation of the concept for the purposes of continued development and growth. For Escobar, sustainable development stemming from the Brundtland Report produced a commodified construction of nature, which was a shift from previous constructions that saw nature as vital and meaningful in itself $-\mathbf{a}$ perception of nature Escobar traces to 'traditional' relationships with nature - to one where its meaning is tied up to the dominant capitalist market system. Thus 'nature' has 
become 'the environment', a "view of nature from the perspective of the urban-industrial system" (p. 52) and but a mere part of the "development apparatus" (p. 53) that fears the scarcity and degradation of natural resources and requires the management of this environment to ensure the survival of society - "clients of the development apparatus" (p. 53). In this framework, not only is sustainability co-opted to legitimate capitalist accumulation, but also, nature itself is co-opted - reworked to be valued only in simplistic terms of what it can contribute to the economy; all other values are marginal.

The notion that sustainability is constructed to enable business as usual with a few minor modifications echoes Doucet's sentiment (expressed in an interview) that, in general, councillors do not take sustainability seriously; they nod to it occasionally but do not make decisions that address sustainability in any meaningful way. Doucet asserts: "I think most councillors ... pay lip-service to the concept of sustainability because it is so much in the press but most of them have no capacity to imagine what a grave situation humanity finds itself in, and as a result, their votes on council are mostly tepid and not very meaningful." One may get the idea that the City of Ottawa and its government is a homogenous force that acts on its own accord. This is not the intent of the above argument. A city is not a monolithic entity and should not be perceived as such. Decisions that are made at City Council meetings are the result of discussion, negotiation, debate, agreement and disagreement; motions often pass or are defeated for political or strategic reasons. Additionally, municipal governance in Ontario is influenced significantly by the provincial government through such bodies as the MMAH and the $\mathrm{OMB}$, and by both the provincial and federal governments through taxation and funding. 
Nevertheless, the institutionalization of a 'development apparatus' that favours capitalist accumulation and growth, and the discursive construction of sustainability within this institutional framework imply the operation of power through these provincial and municipal institutions. For example, according to Councillor Cullen (in an interview), the OMB favours legality and technicality in its adjudication of appeals to official plan policies and City Council decisions. This serves both the development industry and the City well, because both rely on their own (high priced) experts to debate the meaning of this legal and technical language. However, community groups and individuals rarely succeed at OMB hearings, as they are generally unfamiliar with such legal and technical discourses and lack the resources to hire lawyers or planners who do have such expertise. As Councillor Cullen notes (interview), OMB hearings rarely favour communities; the OMB assumes that individual community members lack the expertise to truly understand planning issues, resorting instead to arguments based on values, not legalities:

... when an appeal is thrown to a quasi-legal tribunal such as the Ontario Municipal Board, which looks very much at planning issues, it nods towards community values, it allows the public to address the board - it's a public setting, a public hearing, and the public can address. But the Ontario Municipal Board looks very much at planning issues - legal issues - and is not a forum to deal with the interplay of values. And so the communities feel very frustrated that when they have a council that votes to reflect their values, and are appealed to the Ontario Municipal Board, and the developer most of the time wins, because the interpretation of the Ontario Municipal Board places greater weight on planning evidence ... planning expertise than it does on the issue of values. And it kind of creates the notion that there is a select language of planners that has more import than has the values of community: that the community is uninformed about planning issues, even though it is the community that lives with the result. 
Thus, community needs and desires can only be accommodated if authoritative experts, such as hired lawyers or planning consultants, support them. When the OMB looks at development applications, it focuses on city policy and staff recommendations, not community values. Official plans legitimate discourses of (sustainable) growth particularly developer led growth if the OMB consistently rules in favour of developers. The OMB is powerful in that it legitimizes and normalizes an elitist (quasi) judicial system as the ultimate authority in land-use planning, often even privileging the development industry over democratically elected governments (see Chipman, 2002, for some insights into OMB rulings). Provincial policies, such as forced amalgamations, policy statements, and the existence of the OMB, coupled with the authority of municipal policies and developer influence, lead to powerful (although often resisted and contested) hegemonic discourses of development, growth, and even sustainability.

\subsubsection{Exercising 'infrapower': Resisting the 'development apparatus'.}

According to Cullen (2010, March), OMB hearings are battles of experts that privilege legalistic terms and concepts found in the planning act and official plans, resulting in the silencing of community voices. Emily, a female in her 70 s, reflects upon her feeling of hopelessness during the contested redevelopment of 88 Bellwood:

... it was almost like a done deal before it started ... with the plans for the development and the works and everything, before it had even been approved ... I really felt there was a collusion with the developer and the school board and probably the city - some people on the city. I sound cynical [laughs] ... you know you go to an OMB hearing ... it's interesting ... because the developer, they have their own planners with them 'oh and he worked for the city for twenty years' but now he's a consultant, but they all know each other ... same often with the legal staff. So, as a citizen, it's hard to feel that you can really make an impact ... because of the system and the way it works. 
Despite this frustration, the community and OSCA tried to influence the process.

Councillor Doucet and OSCA attempted to create a public-private partnership between the City of Ottawa, OSCA, and a private developer, which ultimately failed due to municipal budgetary constraints (Ottawa, 2002). OSCA held public meetings throughout the closure, sale, and rezoning of the school property (Jenkin, 2004, 2005). Both OSCA and many residents presented arguments to City Council opposing the rezoning of 88 Bellwood from institutional to residential (Ottawa, 2005c). According to Emily, the community did not influence anything; but others felt they did. Kurt, a male in his 40 s, posits that activism influenced the quality of the redevelopment at 88 Bellwood:

... what we've got there is a good deal. It's ... it's not the deal that I fought for, but it turned out to be ... a good deal. And ... it might even be a better deal because we fought, you know, because Charlesfort had to really come to the table with something ... Charlesfort is a great developer ... they came to the table with quite a beautiful vision of what that street would become.

Exercises of power are not even, nor do they simply flow hierarchically from positions of authority down to a weaker proletariat: Foucault's conceptualization of 'infrapower' sees power as the effects of actions, one upon another, that lead to specific results. Power, therefore, operates within the realm of numerous possibilities: "[i]t operates on the field of possibilities in which the behavior of active subjects is able to inscribe itself. It is a set of actions on possible actions" (Foucault, 1994c, p. 341). Foucault suggests, however, that there are limits to these possibilities and therefore, limits to power: "[p]ower exists only as exercised by some on others, only when it is put into action, even though, of course, it is inscribed in a field of sparse available possibilities underpinned by permanent 
structures" (ibid., p. 340). These structures are important, although not always easy to recognize. What constitutes structures, and to what degree is power constrained by them? Structures exist throughout the particular governmental arrangements within which the Province of Ontario and the City of Ottawa operate. I perceive these structures to be either obstacles or openings within or around which one has to negotiate'permanent' perhaps, but at the same time dynamic. The OMB seems permanent: it has been operating in Ontario in various forms since 1906 (Chipman, 2002). Similarly, official plans have a form of permanence. The Planning Act requires Ontario municipalities to develop official plans; they are developed for specific time frames (20 years with reviews every 5 years) and can only be changed through highly bureaucratic and hierarchical processes involving both the provincial and municipal governments (Finlay, 2010).

But these 'structures' are merely the macro-level obstacles or openings within which power operates. There remain numerous possibilities for subjects to exercise power - to induce others to act in particular ways: to convince city council or a developer to listen to the community at least a little bit; to rework design guidelines and challenge interpretations of the official plan to include these guidelines; to negotiate 'better' zoning that takes community needs into account, not just the 'needs' of developers or planners intent on meeting density targets due to a particular knowledge that requires this for 'sustainability'. Thus, when Kurt reflects on the redevelopment of 88 Bellwood and is able to note the positives, he is in fact referring to those actions upon actions that the 
community association and activists were 'powerful' enough to induce. They clearly did not have all the power (the school and public space was lost) but they had some and opened up the possibility of acting powerfully in the future.

So what about sustainability and dominant discursive initiatives such as Smart Growth and urban intensification? What are the possibilities for exercising 'infrapower'? Through the exercise of power, subjects have the opportunity to contest dominant discourses and to rework them, challenging existing norms and disrupting what counts as truth. Most interview participants accepted dominant discourses of sustainability and intensification, even attempting to reconcile their contradictions to legitimate them as normal and truthful. But are there other ways of knowing sustainability?

\subsubsection{Other ways of knowing sustainability.}

... I saw a definition of dysfunctional the other day ... a family way of relating that essentially undermines the family and is gonna kill it at the end of the day [laughs]. So it's that kind of idea that you're going to be able to live in comfort and ... into the future without killing so many resources. (Kate)

... I would put that in terms of, 'what's a sustainable community?' It's one where your publicly funded infrastructure complements your living as opposed to your dying. (Hugh) ${ }^{37}$

Discourses of sustainability invoke notions of life and death. Sustainability is about the process of living: not only in the 'here and now', but in the future as well sustainability has an implicit temporal lens. Official plans in Ottawa and other cities

\footnotetext{
${ }^{37}$ Hugh made this comment in reference to the construction of Bronson Avenue near Carleton University. This multi-lane lane road separates thousands of students from the neighbourhood of Old Ottawa South, where many students live. Traffic engineers classified pedestrians who would want to cross Bronson as 'traffic interruptions', in effect prioritizing traffic flow over pedestrian safety.
} 
worldwide attempt to achieve sustainability through land-use policies with or without incorporating the needs and desires of communities living with these land-use decisions. The dominance of policies such as urban intensification have been mobilized widely and accepted as a norm within cities; but clearly, not everyone tries to reconcile intensification: some see it as a very disturbing and undesirable process that could very well undermine communities, create dysfunction, and contribute to their 'dying' as opposed to their 'living'.

At the local level in Old Ottawa South, Brisset (2008) feels threatened by the negative effects that intensification has on existing neighbourhoods and feels that such policies need to be challenged: "[a]ny society is predicated on shared beliefs and values whose negative effects can and should be challenged. Some see no evil. Others might have a vested interest in seeing none. We know the city stance and how juicy densification can be in terms of tax revenues" (p. 8). She contrasts the practical results of intensification with her existing (and soon to be gone) urban space as modest but large enough to provide trees and access to sunlight. According to Brisset, discourses of intensification are normalized and legitimated by municipal policies, but result in negative effects and thus should be contested. Similarly, in an interview, Emily relates how intensification (or densification) is harmful to existing neighbourhoods because it changes them for the worse:

A city is very eager for densification because of course that ... it gives them revenue where all the services are already provided. I mean it's just a cash cow for them ... to the point where they see nothing wrong with building a house in the back yard ... And that does affect the quality of life of the people living around there ... there's a whole change in that ... is that a good thing or not? Well, it depends who you talk to. It's good for the city - it's more money. But for a 
neighbourhood: no it isn't. But I don't know how you'd get around that conflict, really. It's part of the official plan. And to the point where the planning ... the planners would ... I am thinking of a case that went to the OMB where basically there's no use anybody from the city going because the official plan says 'yes' to densification. Even though everybody surrounding the monster house in the back yard didn't want it.

She goes on discuss how developers build without regard for the community or the context in which the development will occur. Referring to the Shoppers Drug Mart proposal, Emily contends that:

... it was a developer maximizing the site without taking into context the elementary school next door and the ... already the traffic jams that there are on Sunnyside at rush hour and everything. You know it just didn't seem ... even if they'd figured out something where delivery trucks would go off the street back or make a loop or something behind the building, the whole thing didn't seem that well thought out $\ldots$ it was all in terms of maximum floor space.

Emily sees intensification as little else than a developer-led tool to maximize profits.

Even when discussing Bank Street, a 'traditional main street', she sees increased building heights as serving the development industry rather than the community:

... four storeys I think is very workable but I think six storeys changes a neighbourhood. That's just a personal opinion. But I can see that something like our main street - Bank Street - would get more dense with ... again, some of these are older stores that ... there's maintenance, fixing up, and then, well is it feasible to add another storey of ... you know ... not commercial even; just housing up above. Why not? And this is happening more in the Glebe, but it's ... for a developer, eight storeys gets a lot more money than four. And there's always an argument on that basis.

Although Emily does engage with some principles of Smart Growth in her discussion of what makes a city sustainable, she does not make the same connections with density that Smart Growth does. She certainly makes no connections between intensification and sustainability. 
I think of sustainability as ... where a neighbourhood in a part of the city is a place where you want to be able to live, hopefully have a neighbourhood school where your children can go to that ... you're not on a bus for an hour and a half, shops nearby; you're not car dependent ... you can walk and get on a bus; there are recreational facilities within walking/biking distance ... to me that whole natural component is very nice in the middle of the big city, and I just like the fact that you're not car dependent, that you can walk to things.

Many participants refer to nature as an important component of sustainability, although most prioritize pedestrianism, access to public transit, access to amenities, and issues relating to quality of life. The discursive construction of nature is one of the most striking differences between how residents of Old Ottawa South produce meaning of sustainability and how the City of Ottawa frames sustainability and legitimizes and empowers particular discourses.

\subsection{Discourses of Nature}

Largely absent from the discussion thus far is the first pillar of sustainability: the environment (or natural ecosystems). Poststructural political ecology recognizes that the way society understands, interprets, and interacts with 'nature' is discursively constructed (Braun \& Wainwright, 2001; Castree, 2001; Escobar, 1996). According to Braun and Wainwright (2001), perceptions of nature are produced politically through the operation of power; this view of nature disturbs the notion that nature can be understood with certainty and authority, as any such understanding undermines and excludes the possibility of alternative conceptions of, and actions within and upon, the 'natural' world. This section pays particular attention to the institutional processes that have empowered specific discourses of nature and juxtaposes these with contested claims that individuals 
and collectives (such as community associations) formulate as they mobilize competing discourses of sustainability.

According to Escobar (1996), and further elaborated upon in an urban context by Gunder (2006), the Brundtland Report re-frames nature as a commodity that can be managed as a form of capital within the market economy. In this framework, protection of nature becomes resource management. I would argue that within official planning documents produced by the RMOC and the City of Ottawa, nature has always been understood and valued primarily as a commodity (natural resource, recreational/aesthetic resource) and secondarily as an amenity, the purpose of both being to 'serve' the needs and desires of humanity. I would argue, however, that the Brundtland Report had its effects on sustainability discourses, manifested particularly by a discursive shift in what counts as nature, what the purpose is of nature, where it can be found, and what measures need to be taken to ensure that it is protected in this particular form and location. As the rest of this chapter shows, discourses of urban intensification and nature are linked by the discursive construction of what counts as nature and what policies and practices can be developed to most effectively protect it.

\subsubsection{Planning nature.}

Prior to 1991 , RMOC official plans constructed nature predominantly as a resource used to benefit society (RMOC, 1983, 1988; although see RMOC 1983, p. 1.6, where planning goals include respect for nature and protection of animal and plant life) and create a nature/culture binary; the urban is constructed as the site of human society and built urban form, and the (not yet developed) suburban/rural as the site of non-human nature. 
These rules are discursively produced and are particularly clear within the 1988 official plan, where the overall objectives are to determine what is urban and what is rural, and then to establish where within the rural landscape the important natural resources are located (RMOC, 1988, p. 2.1).

As mentioned in Section 4.1, the 1991 City of Ottawa Official Plan signalled a discursive shift towards sustainable development; it also signalled a discursive shift towards the social production of urban nature. Within this official plan, urban nature is made possible and given emphasis, particularly through the 'greenway' program - an initiative that sought to combine 'built' and 'natural' features within the City of Ottawa: "the Greenway System [is] the primary means to sustain and enhance natural processes in the city, while recognizing its role in providing selected corridors for utilities, scenic roadways and for leisure resources" (Ottawa, 1991a, p. 6.2). The 1991 official plan also prioritized the urban forest, wetlands, and ecologically sensitive development (although within this plan, wetlands have 'value' based on a narrow rationale - as settlement ponds for stormwater - with the primary purpose of sensitive development being to protect groundwater and reduce soil degradation; Ottawa, 1991a, p. 6.4). The 1991 official plan continues from previous ones in its construction of nature as a resource for societal use, but it challenges the nature/culture binary by integrating the built and natural environments, and creates nature - discursively and materially - through such initiatives as the greenway program. Discourses of nature shift again in the latest official plan: the 2003 City of Ottawa Official Plan. 


\subsubsection{Officialized discourses of nature in the new millennium.}

As mentioned in Section 4.1, the 2003 official plan focuses strictly on land-use and all other priorities are shifted into the planning program called Ottawa 20/20 (Ottawa, 2007b). Within this official plan, nature is discursively produced in terms of land-use, and is incorporated into categories based on geographic location, utility to the built environment (e.g., stormwater management), and as special features warranting protection (usually outside of the urban setting; e.g., wetlands and other environmentally sensitive areas; Ottawa, 2007b). This section focuses on current discourses of nature operating in the City of Ottawa.

Current municipal governance in Ottawa operates within a hierarchical policy arrangement, with the official plan having the most - and provincially adjudicated authority (MMAH, 2009); the other components of Ottawa 20/20 provide direction but have little legal authority to influence land-use issues. The City of Ottawa constructs the official plan as being but one part of Ottawa 20/20 (Figure 4.3); however, the official plan is the only one legislated by the Planning Act (Ottawa, 2010b). Therefore, for the purposes of urban development and intensification, the official plan is the most powerful policy tool within Ottawa's planning hierarchy (Figure 4.4).

The separation of land-use planning from other priorities, such as social and environmental planning, has discursive and material implications and illustrates the operation of power within current governance and policy development in Ottawa and Ontario as a whole. Nature is constructed in juxtaposition to culture. 'Development' of this nature is the central planning and policy issue: development is a norm - an assumed 


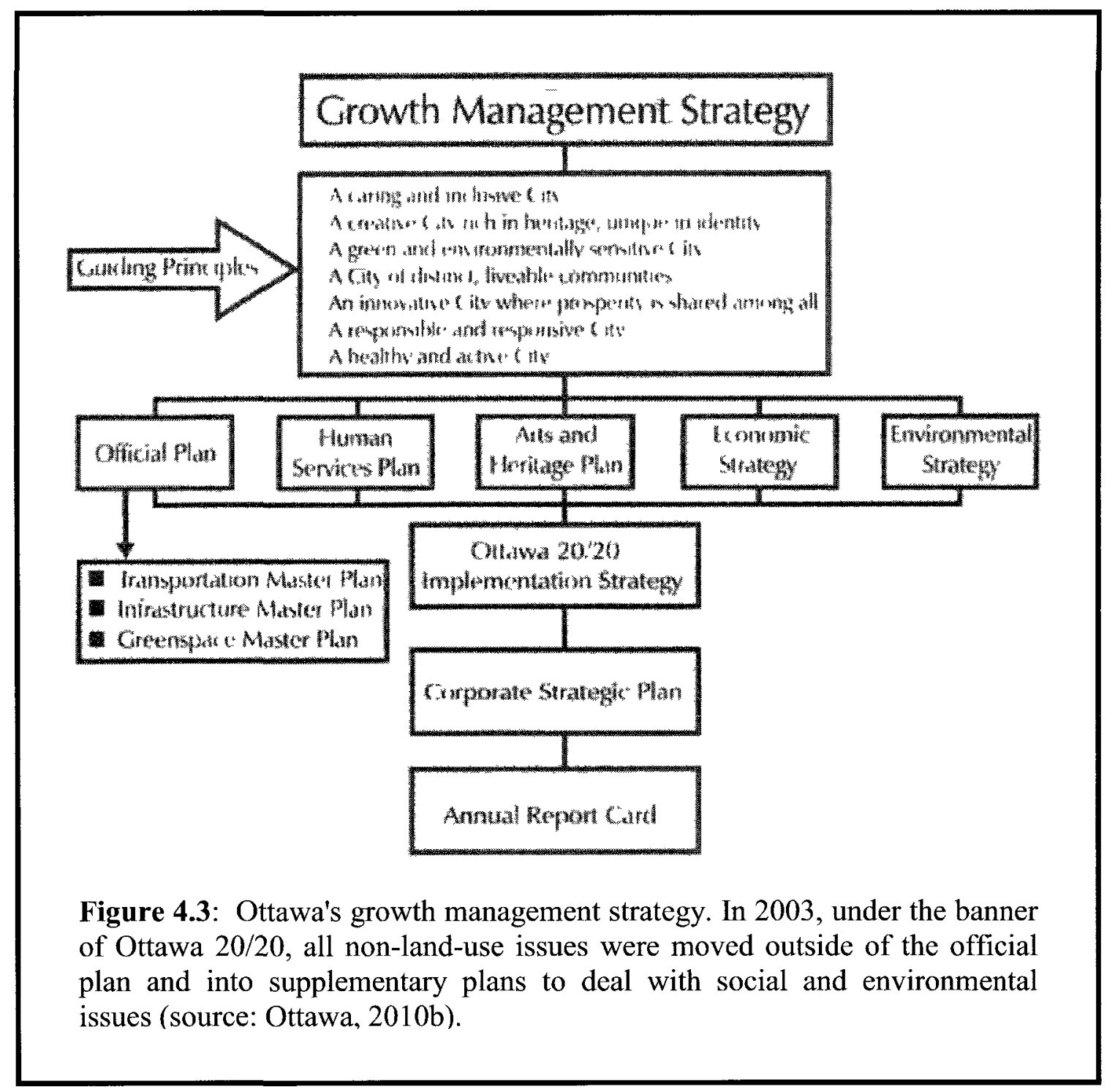




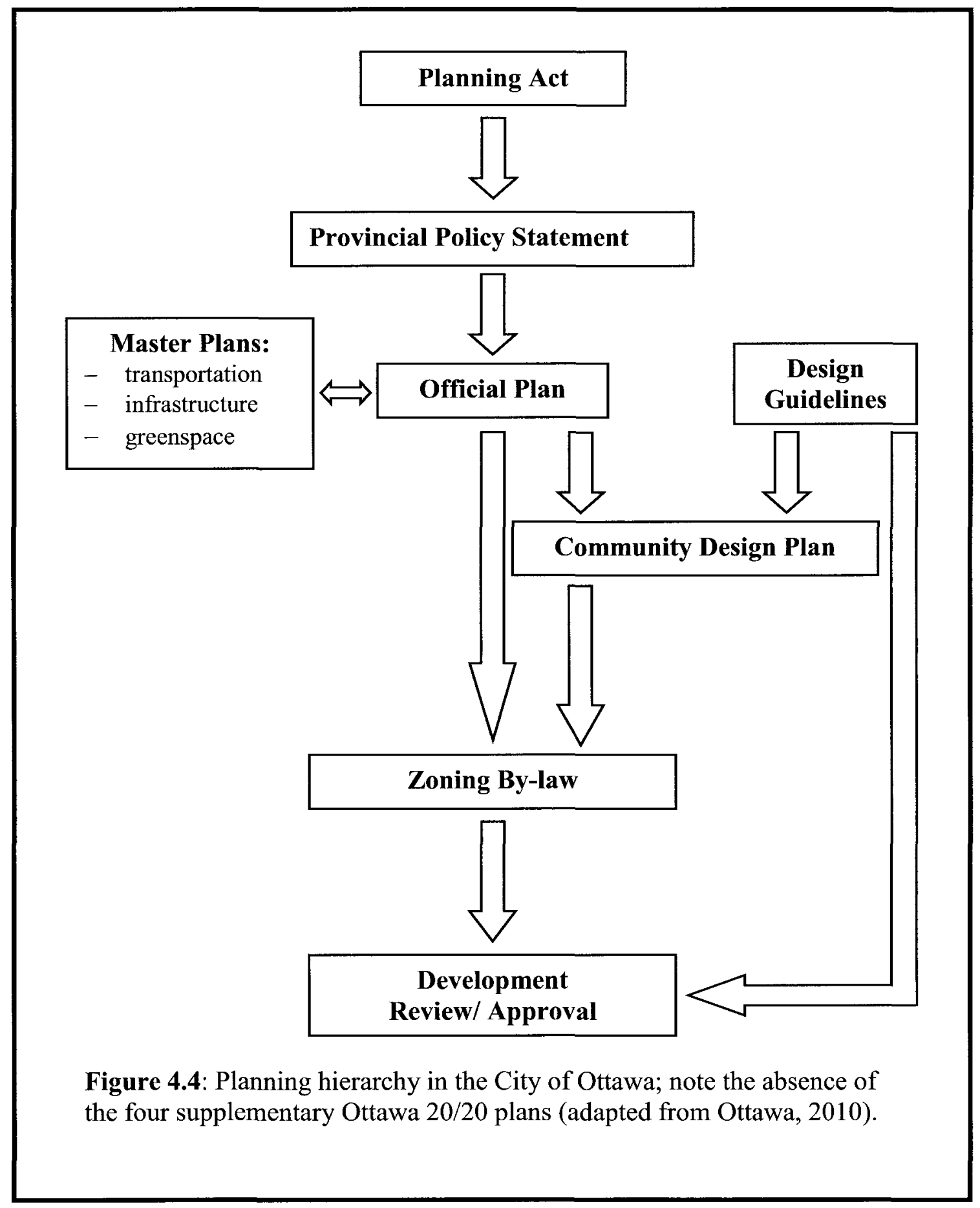


marker of progress; 'management' of nature then follows and presupposes that transforming nature - urbanizing nature - increases its value. Within an assumption of development, the City of Ottawa then mitigates for 'negative externalities'. As Doucet explains (interview), the City of Ottawa, through its policies and Council decisions, does not take sustainability seriously but genuflects here and there to sustainability without giving it much meaning.

Publications such as Getting Greener: On the Path of Sustainability (Ottawa, 2007d) are perhaps manifestations of these genuflections that attempt to mitigate the more egregious affects of urban development on the environment and to respond to scalar discourses that locate cities as the most appropriate sites of sustainable development. This document is a directory of environmental initiatives intended to "keep Ottawa clean and beautiful and to ensure a sustainable environment for future generations" (p. 3). Amongst other things, this publication attempts to complement the official plan by providing a strategy for developing "in harmony with the environment" (p. 13) because "without clear guidelines, it is impossible to preserve and enhance the quality of our natural environment. To contain Ottawa's ecological footprint, development needs to be guided by our environmental framework" (p. 14). Yet land-use planning and this environmental framework do not exist on the same hierarchical plane. What counts as nature, therefore, are those elements that can be removed from the authority of the official plan. Some practical manifestations of this strategy are: the creation of ecological sensitive areas, which must be purchased by the City in order to be protected (Ottawa, 2010b); urban development guidelines, which have less authority than zoning by-laws 
(e.g., Ottawa, 2005b); and brownfield remediation programs, which cost the City money and have yet to be implemented (Ottawa, 2007a). Nature is reduced to what growth leaves behind as residual, marginal, and outside the realm of value established by the market economy.

Within discursive constructions of nature as a resource, spaces outside the urban area - specifically agricultural lands - are considered 'greenfield' whereas open spaces within the urban area, especially in those areas the city targets for intensification, are considered 'underdeveloped'. An illustrative example of this designation is an area of open space near the Sunnyside Library in Old Ottawa South. In 2008, a local property developer proposed redeveloping the library site (open space and the existing library) within a public private partnership, to more fully intensify the space while retaining the library; while the proposal lacked Council or public support, the ward councillor Clive Doucet nevertheless labelled the site 'underdeveloped' (Doucet, 2008). As a valuable unit of land located on a 'traditional mainstreet' (a target of intensification), this area is constructed not as greenspace, nature, or even as institutional (public) space, but as valuable, under-developed real estate.

This discursive construction that frames nature in juxtaposition to urban development, privileges those areas that are either outside of the urban, identified as special in some way, or linked to recreational activity - a use that can be commodified and considered a resource, especially if it linked with other uses, such as schools, rinks, or playing fields. According to official plan policies that encourage intensification, nature counts less if it is located on land with high market value. In Old Ottawa South, 
this form of nature is mostly located in public parks, some of which are on 'residual' spaces (Osborne Park; Linda Thom Park), on former garbage dump sites (Brewer Park), or on floodplains that cannot easily be developed (Brewer, Brighton Beach, Linda Thom, Osborne, and parts of Windsor Park). It is certainly not found on sites such as 88 Bellwood, which was also considered 'underdeveloped' real estate in its former designation as institutional (public) space (Ottawa, 2005c).

Discourses of urban intensification rely on particular constructions of nature and are legitimated by scalar discourses of sustainability that call on cities to reduce their ecological footprints for the sake of the planet. Discourses of intensification see the urban as the appropriate site of the built environment and separate it from the natural environment; furthermore, these discourses privilege constructions of nature as natural resources, including agricultural land, mineral resources, and special conservation areas (outside of the city) that can be protected if higher density development can restrict urban sprawl. As such, discourses of intensification construct 'local' nature as suburban, exurban, or rural, and in a more global context as something that can be protected by the efficient use of resources. Where these institutional discourses of nature depart from those constructed by the interview participants is in the degree to which nature is valued as a natural resource as opposed to other ways of valuing it, where nature can be located in order to be considered 'natural' and 'valuable', what counts as nature (especially within the central urban area) and how urban nature is (under)valued within the framework of urban intensification. 


\subsubsection{Constructing nature in Old Ottawa South.}

As this next section shows, interview participants in Old Ottawa South construct nature much differently than do the various official plans in the Ottawa region, which lead to practices that compartmentalize and categorize nature in ways that are often incompatible with discourses of nature operating in Old Ottawa South. Most interview participants refer to elements of nature within sustainability discourses; although many participants construct nature in terms of greenspace, urban forests, and various aspects of public space and landscapes, there is also much engagement with nature as a resource (similar to how official plans create nature). Many participants refer to the built urban environment within this discursive construction of nature as a resource. Arguing that communities like Old Ottawa South would have to make some fundamental changes within the next few decades, Guy, a male in his $60 \mathrm{~s}$, focuses on the built form as one means by which nature can be conserved:

... I could see having to make, I mean, really serious changes. Not just putting a little bit of insulation into the wall and putting in funny film on the windows and stuff, I mean a... much larger step in the improvement of ... energy use of the older homes in Ottawa South ... obviously a row house ... a long row, like in Europe where you have thirty or sixty segment homes along a street, there's much less energy use ... the single family dwelling, as separate as it is here, with a bit of garden around it, at least two, or, in our case, four sides ... is ... may not be the universal model in very near future.

Here energy efficiency is prioritized over green space and changes in built form are seen as a move towards greater sustainability. Similarly, Kate refers to the way the built environment can contribute to more efficient resource use. She recalls a visit to Sweden where she noticed that the built form in Stockholm uses resources more efficiently: 
... all these different communities and different places, you have a downtown core, generally, which is mixed commercial / residential, but every building essentially is ... several storeys high: three, four, five storeys high; it maybe tops out at six storeys, kind of. Some are older; some are newer. Everybody sort of lives in a smaller space - mostly like an apartment. You get a little further out from the downtown core ... and you may get something like a subdivision, with ... houses that are on their own, but they're much smaller. All these things are much smaller. And everybody sort of bikes everywhere; bikes or walks.

Kate continues with a description of one community in Östersund, Sweden, that uses a central heating facility run by burning forestry by-products and by collecting surplus energy from other industries during off-peak hours:

... they have built a central heating facility that heats all of the buildings within a certain large ... very large area, centrally from town. So each little building doesn't have its own little furnace ... they're all sort of hooked up to this central heating unit and then where they get the heat from, is partly they're burning a lot of waste wood, since it's a community where, where a lot of ... where they manage ... forest lots and manage forests and that kind of stuff so they have a lot of waste wood to burn, but also they have some kind of agreement with industry, so that at night, when the industry ... the various industries nearby don't need their ... it's like their excess or surplus energy, of some sort ... and then I compare it to what's here, and we live ... in these little boxes that have their own little furnaces, but also were generally built at a time when furnaces were not that common and they were huge and cumbersome ... sometimes wood stoves were what heated the building. It's cold. It's draughty. The floor plans are badly designed ... not a lot of storage ... they're much bigger by way of area than ... generally what's in Sweden, but ... it's much less efficient.

The above two participants focus on resource use and efficiency in these discussions of built form. Built form is a common theme within discourses of nature that focus on the way society uses nature to satisfy their daily needs, particularly in terms of ecological footprint and resource use. As Section 4.4 illustrates, urban intensification is constructed by many, including Councillor Doucet (2007), as a way to minimize society's ecological footprint vis-à-vis the efficient use of resources. 
As a discursive construction, efficient use of resources is a 'truth' accepted by all participants. The practical means to achieve this efficiency is less clear - such that discourses of intensification are contested - and what form the urban landscape should constitute is often hotly debated, particularly when community members, planners, and other social actors prioritize and value different things. Discourses of urban form often butt up against discourses of heritage and community (the focus of Chapter 5), where the rules of efficient urban form (e.g., high-rise condos) conflict with other (communitybased) constructions of what the streetscape and built form should look like and how it should function.

According to Kate, there are many ways to use resources efficiently: "I imagine there are many different ways of doing that; I don't imagine that there's only one way of doing it. And, you know, people experiment over time and then find what works. Which also means that you kind of have to be willing to experiment and to do things in a different way and to figure it out." Finding what works is not as simple as imposing a specific technology or built form on a neighbourhood without accounting for the people living there or other components that would contribute to sustainable urbanism. According to Hugh, efficiency-based initiatives can in practice be inefficient and unsustainable in the longer term. He points to isolated attempts to 'create' sustainability using technologies that fail if they are not combined with other factors, such as public transit or suitable locations:

... if you build a green building that isn't served by public transit, you can't walk to it, or whatever, it's just an orphaned, stupid, you know ... the building itself may save you fifteen percent or twenty percent - fifty percent in energy costs, but to get 
there costs you a whole lot. So, location is a big thing ... a lot of your heritage buildings tend to be in more central locations ... so ... make them accessible, you know, it's that whole understanding of full ... value chain and the full negative externalities.

Hugh acknowledges that there may be energy saving with 'green' buildings, and this may be a good thing, but only if it is done without compromising other ways of being sustainable and without ignoring external costs, such as transportation. Furthermore, he engages with many concepts from the heritage preservation movement, such as embodied energy and adaptive re-use, as ways through which existing buildings can be made more 'green' (see for example, Frey, 2008; Rypkema, 2004):

... some say some of the greenest buildings you have are buildings that are there already, you know, if you think in terms of the energy cost ... to knock a building down and to dispose of it and whatnot, versus whatever you put up there, that has, you know, higher R-value ... preserving a lot of stock that you have is probably ... sustainable. Again, it comes down to policies and that. Can you retrofit in such a way that you will, you know, to the extent possible you can make them as energy efficient as possible. They're never going to be as energy efficient as, again, stuff that ... new construction, but I mean I don't know enough about ... I don't know enough about the life-cycle costs of buildings, but ... does it make sense to have a huge capital cost and a bunch of other negative externalities to put up a new building ... either on site or somewhere else, if it triggers other things?

In these quotation, Hugh engages in the notion of resource use and efficiency, but adds a layer of complexity by addressing the context of the built environment and by questioning the dominance of sustainability discourses that privilege new building technology, rather than including 'externalities', such as transportation costs and the need to continuously extract new resources to satisfy the new (sustainable) housing market. Caroline similarly questions the merits of 'green' buildings, but focuses on their impacts on existing communities and greenspace: 
The new houses are ... especially the ones that are, you know, trying to achieve LEED, you know [laughs] or other, sort of sustainability goals, they tend to be ... because it's so expensive to do that they are doing maximum build out and I have yet to see an example in our neighbourhood where the front trees can be saved because the other thing is the way the city's rules work is everybody's building garages; they're building garages at the street level; that means their porches are either high up or not there ... there's a lack of relationship with the street but from a purely environmental sustainability issue, I would say it's also changing the appearance of the neighbourhood and it's removing trees that could be used as an alternative to heavily sealed [laughs] houses. So, I live in a house with big trees all around me. I use my air conditioning maybe two days.

This quotation makes reference to a particular construction of nature as a resource: one that sees natural elements, such as trees, as integral to the function of the built environment. However, Caroline criticizes technological and incremental efforts to achieve sustainability; due to their high cost and lack of relationship with the neighbourhood, they often fail to make neighbourhoods more sustainable and likely make them less so. In this quotation, nature is still seen as a resource, but it is a different kind of resource. The location of nature is within the urban setting and it is directly related to the built environment, as opposed to more global constructions of nature that are focused on energy or building materials and are distanced from the built environment.

Caroline's construction of nature also harkens to a past view of urban planning and urban form, epitomized by the garden city movement ${ }^{38}$ (e.g., Creese, 1966), that views trees as a particular natural element working in concert with, or in place of, building technology. With increased reliance on air conditioners, air purifiers, and other technologies, trees become less important as a resource. Caroline links current shifts in

\footnotetext{
${ }^{38}$ Caroline refers to the garden city as 'a very Christian response', where society was trying to re-create Eden. I expected my research to uncover discourses of nature that include some form of religious response, either drawing on the Christian concept of stewardship, or concepts from eco-centrism that place a moral and intrinsic value on nature. However, my research did not yield any such results.
} 
urban form to a devaluation of urban trees as a resource: "when these houses were built in the early twentieth century ... there's a very clear understanding of the role of trees to help moderate the summer heat and there was also a very clear understanding of the role of windows for ventilation and for light, and there ... it was built as a sustainable community." Caroline's focus is on the role of trees, perhaps due to their prominence in Old Ottawa South, and due to her perception that trees are currently being threatened by infill development. Similar to Caroline, Lydia values trees and references the garden city movement, but she also makes a connection between nature and community:

I think we need the public green spaces - the public landscapes; I think they help define ... your community. I think they help provide meeting places ... for the community. They provide ... environment ... you know, they used to call it in the early nineteen hundreds breathing ... the lungs of the city. I mean, you need that. You need ... you can't ... well, you can't ... it's nicer not to be living in just concrete.

For Lydia, nature does many things, including contribute to the built environment, but she also refers to a more holistic and esoteric function of what nature does: nature helps define community by facilitating community engagement and interaction. Furthermore, nature, according to Lydia, makes cities more liveable by moderating the harshness of a built landscape dominated by concrete. This juxtaposition of what counts as nature versus the built environment is central to discourses of nature that view the county (as opposed to cities) as the normal setting for nature. When urban settings do contain nature, it is an unexpected and pleasant surprise that makes for an improved urban experience. Emily engages in this construction of nature as a welcome surprise within an otherwise 'artificial' landscape of the built urban setting; it is a deviation from the norm to have nature within the city: "[m]ost of Ottawa South is along the river ... that whole area, 
to me that whole natural component is very nice in the middle of the big city ... [w]e get up every morning and say 'Ohh, it's ... we're lucky to live here' ... it's like being in the country in the middle of the city." Emily constructs nature as something separate from, but still possible within, an urban context. Furthermore, this nature is integrated within the urban such that nature and built environmental are intermingled and can be experienced concurrently.

The residents of Old Ottawa South interviewed for this thesis construct nature based on their own day-to-day experiences; although they invoke to some degree globalizing discourses based on resource conservation and efficiency, their perception of nature is much more complex than officialized discourses of nature operating within the City of Ottawa municipal government and evident in its official plans. The complexities of sustainability discourses and discourses of nature are made apparent when the effects of municipal policies (such as 'inappropriate' developments, particularly those 'authorized' by the OMB) conflict with the needs and desires of communities in which these effects occur. Most participants construct nature with the possibility of being urban or rural, public or private. It is a holistic entity constitutive of their environment, not categorized into discrete elements that must be located in certain spaces and subject to protection and management by authorities.

\subsection{The Social Construction of Sustainability in Ottawa: Conclusions}

As this chapter shows, hegemonic discourses of sustainability are empowered and stabilized by scalar and institutional frameworks that normalize the terms of these discourses. Official plans in the RMOC and the City of Ottawa have evolved since the 
1970 s, and this evolution is a reflection of the shifting discourses of development, growth, and sustainability operating in the Ottawa region. Current discourses of urban intensification - as urban sustainability strategies reliant on discourses of growth - are widespread both within institutions, such as municipal and provincial governments, as well as among many social actors in Old Ottawa South (although not all). The terms of these discourses are contested, particularly as the practical manifestations of intensification increasingly conflict with the needs and desires of those individuals living with higher housing densities, less public space, changes in urban form, and a decrease in 'soft' infrastructure, such as schools and other institutional spaces. Discourses of nature are also shifting: mobilized for political and economic purposes by municipal government, property developers, community members, and others; the terms of these discourses are also contested, particularly when community members deem their practical effects to be unacceptable. As Chapter 5 illustrates, other discourses, namely heritage and community, are also mobilized by governments, developers, and community members to achieve particular goals and to contest policies and practices that conflict with their own values and constructions of sustainability. 


\section{Chapter 5: Discourses of Community in Old Ottawa South}

As discussed in Chapter 2, both community and heritage are discursively produced concepts often invoked during the contesting of specific urban developments. Chapter 5 outlines the ways in which the City of Ottawa, through its policies and practices, claims 'community' as either a site for sustainability initiatives, or as the 'recipient' of these sustainability initiatives that facilitate development in an 'appropriate' manner. In many ways, the City of Ottawa refers to 'communities' or 'neighbourhoods' as simple geographic areas, delineated for such purposes as localized sub-governmental organization (i.e., community associations), manageable planning areas, and comparable census units for statistical purposes (the boundaries of Old Ottawa South approximate federal census tract numbers 5050016.00 and 5050017.00; Statistics Canada, 2007). Nevertheless, this physical delineation is one way in which communities are given an identity, and as this chapter reveals, identities often become politicized, with effects that can empower or disempower communities. This chapter also illustrates the ways in which residents of Old Ottawa South contest normalized constructions of community, challenge the notion of fixed community identities, and rework their identities with respect to community and heritage to become 'activist', 'opposed to' or 'politically engaged' citizens as they respond to perceived negative changes that affect their lives.

Section 5.1 traces how contemporary urban planning models construct community in relation to urban form and how interview participants respond to these notions of community. Section 5.2 challenges assumptions within the popular ideals of 'creating 
community' by drawing on literature - particularly, although not exclusively, poststructural political ecology - that insists that community (like sustainability) is discursively produced, is laden with power and politics, and has multiple meanings and scales. Poststructural theorizing disturbs an understanding that community is a simple and transparent entity, of which one can simply claim or reject membership. Section 5.3 discusses the implications for urban development within the broader discussion of the political and power negotiations that shape community identities, and investigates how communities react to urban developments that are perceived as a threat to daily life. Finally, Section 5.4 concludes the chapter with some musings around Gibson-Graham's (2006) reading of 'weak theory', for the purpose of challenging residents of Old Ottawa South to remain hopeful and engaged in creating futures of possibility, even while contesting perceived 'threats' to its sustainability, community, and heritage.

\subsection{Creating Community}

Planning models such as Smart Growth and New Urbanism claim an ability to create community using appropriate urban form. New Urbanism seeks to create this urban form via urban planning and architecture that 'make communities work' (Katz, 1994). Compact, close-knit communities, claims Katz (1994), can be achieved through urban design; furthermore, New Urbanism purports to be an antidote to urban sprawl, which apparently has "fragmented our society - separating us from friends and relatives and breaking down the bonds of community that had served our nation so well in earlier times" (p. ix). Katz goes on to link suburban sprawl with crime and the degradation of society: "the costs of suburban sprawl are all around us - they're visible in the creeping 
deterioration of once proud neighbourhoods, the increasing alienation of large segments of society, constantly rising crime rates and widespread environmental degradation" (ibid.). This construction of community makes connections between social behaviour and the spatial-temporal arrangements that particular urban forms produce. Thus, an appropriate urban form, suggests Katz, can offer the space and time in which groupings of people can become 'community' and within which a 'sense of community' can be fostered. Smart Growth also engages with this idea of creating community by nurturing a 'sense of place' within developments through intentional design (Tregoning et al., 2002), although Smart Growth is more about sustainable land-use than community. Unlike Smart Growth, which is a relatively flexible set of principles intended to make growth more sustainable, New Urbanism more explicitly relies on a specific built urban form that draws largely on neo-traditionalism; it cites post-World War II urban sprawl as the antithesis of this compact and vibrant neo-traditional urban form; sprawl represents "disinvestment in central cities ... and the erosion of society's built heritage" (CNU, 2001, p. 1). New Urbanism's antidote to the evils of urban sprawl is to use urban design and architecture to create 'real' neighbourhoods (ibid.); as such, it is attractive to urban planners, policy makers, and the broader public because it claims to offer real solutions to perceived economic and social problems in cities and harkens to an idealized view of the past that sees close-knit village life as the ideal American community (Katz, 1994).

Yet New Urbanism fails to deliver a spatial-temporal solution to sprawl when its developments are built far from urban centres of employment and services, and this is one of its most widely cited criticisms (e.g., Angotti, 2002; Grant, 2006a; Marcuse, 2000; 
Marshall, 2000). For example, McKenzie Towne in Calgary, established in the late 1990s, was one of the first New Urbanist or 'neo-traditional' developments in Canada (Cox, 2000; Grant, 2006b). It was built at what was then Calgary's southeastern edge, approximately 21 kilometres from downtown Calgary; its only access at the time was Highway 2 (Deerfoot Trail within Calgary), the main north-south road artery in southern and central Alberta (Cox, 2000). It was built in a style that its developer described as neo-traditional and Victorian: "[p]icture an old-style neighbourhood with bustling High Street shops and classic homes featuring welcoming front porches. Add a town square with a 92-foot clock tower and Victorian bandshell. This is McKenzie Towne, Carma's neo-traditional community" (Carma, 2009). Implicit in this image is a sense of place and community: by harkening to an image of the past that portrays small town life as quaint and close-knit (although still 'bustling'), developments that are built in the appropriate style can then make claims of facilitating a vibrant street life, welcoming homes, and an urban form that serves to create community.

Yet McKenzie Towne is a suburb of Calgary, located as far from Calgary's urban core as was possible at the time (within city limits), and is serviced only minimally by bus service (Cox, 2000). It is neither pedestrian oriented nor is it an employment or transit hub, foregoing claims to 'sustainable suburbanism' that models such as TOD arguably justify. Furthermore, it fails to achieve higher population densities than conventional suburbs in Calgary (Grant, 2006b). Cox's (2000) assessment of McKenzie Towne as a New Urbanist neighbourhood is particularly critical: 
McKenzie Towne will attract people seeking a life style in a setting physically reminiscent of the ideolized (if not ideologized) small town. But its success appears to be in architectural design, nothing more. Even when fully built out, it is likely that nearly as many vehicle trips per capita will be produced in McKenzie Town [sic], just as has occurred at high density residential developments near US rail stations. It is likely that the overwhelming majority of work, shopping and other trips will take residents outside this community that is just as inopportunely located relative to Calgary's activity centers as adjacent conventional suburban developments. Beneath its traditional, retro design core beats the heart of suburbia. (para. 11)

Marshall (2000) echoes the criticism that New Urbanist developments are merely welldesigned suburbs and as they ultimately legitimate sprawl, do more harm to cities than good. According to Marshall, New Urbanist developments are

... conventional suburban subdivisions draped in the clothing of urbanism. This means gridded streets, front porches, smaller set backs, and so forth. But they remain isolated developments, sitting off main highways, linked by necessity to the local shopping mall and defined by the automobile ... [m]ore serious measures - like curbing highway spending or regional-growth boundaries - are given lip service or actively criticized. (para. 2)

New Urbanism does much more than adopt 'city beautiful' standards to create unique developments. Within the (largely architectural) principles of New Urbanism, offers Gandy (2006), "[a] deterministic conception of spatial form as a dominating influence over human behaviour is combined with a form of ecological nostalgia for an imagined past" (p. 66). This nostalgia is not simply ecological, but, according to Talen (1999; citing Krier), New Urbanism relies on imaginaries of a "small-town philosophy inherent in traditional neighbourhood design" (p. 1362) that draws on the social superiority of this small-town life. As such it is not explicitly a sustainability model: it is planning model meant to reconcile (once and for all according to Harvey, 2003) particular utopian ideals 
of urban form that New Urbanists perceive to be superior to current forms, which if realized, can result in improved behaviour (Talen, 1999). Privileging the utopian ideals of New Urbanists ultimately leads to the silencing of 'Old Urbanists', or whoever's ideals do not fit within the framework of New Urbanism. The sharpest criticisms of New Urbanism come from those citing social justice and equality issues. For example, Marcuse (2000) cautions that New Urbanism privileges the wealthy, considers the utopian ideal to be a small town with "no mix of races, no very poor, no very rich, few singles, none with discordant sexual preferences" (p. 4) and that New Urbanist developments sometimes 'need' to displace the poor and marginal (for the lowest possible monetary cost) for the purpose of creating 'utopia'.

In contrast to New Urbanism, Smart Growth explicitly focuses on urban form and land-use (rather than utopian social planning initiatives), purportedly reconciling growth and sustainability in the process (Filion, 2003). Although it shares many principles with New Urbanism, Smart Growth prioritizes urban structure over design, and thus insists on incorporating transit, a mix of housing options, and access to employment within urban developments (SGCN, 2007). Its goal is sustainable growth, not the creation of particular utopian urban forms, although actual practices that use Smart Growth often rely on claims to achieving such goals as community-creation and place-making (see for example, Krueger \& Gibbs, 2008).

Policy makers, such as municipal governments, find useful an understanding that community and sense of place can be included in normative planning principles. Yet normative planning privileges particular constructions of community (and sustainability), 
resulting in policies and practices that encourage particular urban forms and architectural designs. Indeed the City of Ottawa, in its official plans and various design guidelines, turns to such things as TOD, zoning, and intensification in an attempt to build a sustainable urban environment that in turn creates (sustainable) communities. Thus, in terms of urban planning and development, the City of Ottawa, through its expert urban planners and architects, claims the ability to 'create' community via land-use regulations, such as zoning bylaws and density targets, engaging with principles of Smart Growth and New Urbanism (among others) to do so.

The City of Ottawa has attempted to make connections between urban intensification and the creation of 'vibrant' communities in a number of ways. For example, Ottawa (2008a) outlines ways to "nurture thriving communities" (p. 48) by increasing the density and mix of residential dwellings. Consistent with New Urbanist principles, Ottawa (2008a) proposes that by increasing the amount of people and personal interactions within a given space and time, these increased opportunities for social engagement will create a sense of community. Another City of Ottawa publication, City Housing Strategy: 2007-2012, describes what it deems to be 'healthy' communities: those that, "minimize their impact on the ... environment, are socially inclusive, complete with an array of housing options and supports, and are responsive to and supportive of broader economic and social development goals" (Ottawa, 2007c, p. iv). This publication then suggests that appropriate housing (i.e., compact, dense, affordable; p. 1) determines social inclusion in neighbourhoods, economic prosperity, and improved individual and 
environmental health (pp. 4-6). Similarly, the City of Ottawa's twenty-year growth management plan, Ottawa 20/20, claims that a sense of place and identity can be developed; it proposes to do so through the appropriate design of Ottawa's streetscapes, through processes of urban revitalization, and by the incorporation of art and historical references that draw on ideals of Ottawa as a "city of villages, distinct neighbourhoods and rural enclaves" (Ottawa, 2003a, p. 13). Similar to Smart Growth and New Urbanism, these City of Ottawa publications make direct connections between the built environment and particular features of community. Within these publications, urban planners are charged with the task of creating community and contributing to and enhancing community identity through the use of built form. Implicit in this task is the notion that community is predetermined, simplistically defined, and easily understood, especially by those considered experts in the field of urban planning.

Some interview participants engage in the idea of creating community; several point to physical aspects of the urban landscape that facilitate social engagement (although none claim that the physical environment 'creates' community). These participants suggest primarily that the physical layout and components of the urban environment can facilitate a 'sense of community' by providing space and time for social interaction. For instance, Caroline supports the notion of a walkable community: "I think walkable neighbourhoods really work ... when you walk down the street you have connection with other human beings. We are naturally social people ... you have a sense that you're part of a community." Similarly, Lydia stresses the importance of public 
space for facilitating social interaction: "I think we need the public green spaces, the public landscapes, I think they help define ... your community. I think they help provide meeting places." The physical interaction of people seems to be the starting point for these participants, in terms of how individuals become part of a community.

Lillian refers to elements of the built environment that contribute to the creation of community: "you need to have a lot of meeting places ... churches, schools, pools, rinks, parks, like, all the shared places - meeting places ... that's the primary thing. Because that's where people make all the connections that create community." The focus here is not on designing neighbourhoods in a particular way or creating particular types of streetscapes that lend themselves to interaction. The focus, rather, is on the need for shared space - for public community space. This shared space, coupled with the availability of time to use this space, brings the physical components of the urban environment into the framework of social interaction, contributing to a shared identity based on a spatial-temporal component of daily life. Thus, according to Lillian, the urban environment can provide sites for community engagement.

Clayton relates to the physically defined urban landscape of Old Ottawa South as a setting within which individuals can engage in community activities, particularly through daily interactions. Layered on top of this physical setting is individual interaction, not necessarily in an organized way, but through more organic processes within daily routines in everyday places:

... one of the best things we've got going for us ... [we] have an almost natural boundary ... basically the river - the curving river, the canal, and Carleton ... we've got this ... wonderful geographic ... natural community, right here ... losing the Fresh Fruit was so important ... it's not just a question of convenience, being able to 
walk, but you see your neighbours there; you stop and you talk ... what a lot of people don't realize is that's been taken away too. It's like when they closed the school; there's a lot more than ... kids not being educated - little kids not having a place to go and they gotta go to the Glebe, it's a lot more than that but they don't ... nobody measures that.

The above participants value personal interaction, friendliness, and connection with each other; they suggest that these social aspects instil in some a sense of belonging and membership to the community of Old Ottawa South. This construction of community identity privileges individuals who might value this type of social interaction, or whose daily routines facilitate personal interaction at such places as schools, stores, and parks. Some individuals may indeed construct their identity as members of this type of community. But surely there are other constructions of community and identity as well; and cannot personal interaction and social engagement occur in neighbourhoods that are considered less walkable than Old Ottawa South? To this end, both Caroline ${ }^{39}$ and Kate are less convinced that sense of community is to be found within the daily interactions in the neighbourhood:

I see it [community] more in its own separate little discrete parts than as an overall community with concerns, except when it comes to things like Lansdowne. I think everybody around here is pretty adamant that that's an awful thing. I don't think we've been real effective at dealing with it either ... but there's other people within the larger City of Ottawa who feel the same as we do and there's, you know ... and individuals can ally themselves with those groups without worrying about what we're doing here in Old Ottawa South. (Kate)

\footnotetext{
${ }^{39}$ During the interview with Caroline, I noted that there seemed to be some contradictions with her responses, although by reading the context of the conversation, the response need not necessarily be read as contradictory. I felt these apparent contradictions were insightful, illustrating the complexity of the subject matter and highlighting how people feel about what makes community is not necessarily how they practically make community for themselves, or that community is contingent, based on other factors that also contribute to social engagement, rather than simple interaction on the sidewalk.
} 
I don't feel part of a ... social community or social network in Old Ottawa South. Like, I feel part of a social network on my street and ... our street has always been, ever since I was ... ever since we moved there, I moved into the neighbourhood when I was ... like many people I moved in when I was pregnant ... but I moved in in the winter ... and what I didn't realize until a few months later when the snow disappeared - it was a terrible, terrible winter - was that the street was polluted with children. And it is still full of children. And I think a lot ... because of that, a lot of neighbours know each other. Because your kids play together and fight with each other and you get to know people that way. And I think that's what really links our street together, is the fact that it's just constantly full ... renewed through people moving in with children. And people moving out but still more kids. And in our street even a lot of people have taken over the houses of their parents. So the kids that you saw ... you know, they're now the parents on the street. They were the children on the street. I'm not convinced that's very common. So I think that's a really strong part of what makes it a community. (Caroline)

Both Kate and Caroline see community as something more than simple personal interaction within the neighbourhood; Kate in particular suggests that community need not be defined by the spatial configuration of social engagement, such as interaction 'on the street' in Old Ottawa South. Individuals find community and are part of communities outside the neighbourhoods where they live and may or may not feel a sense of community within it. Caroline draws on a particular identity - that of parent - to highlight what gives her street one kind of identity and how community is created based on that identity. Both Kate and Caroline are referring to more than a pre-existing entity called community, with whom one finds a way to claim membership; they are referring to the social construction of community.

\subsection{Discursive Constructions of Community}

An increasing number of scholars, particularly within the realms of psychology and poststructural theorizing, have disturbed the presupposition that community can be fully understood, and therefore created, by appropriate land-use planning. For example, 
Columbo and Senatore (2005) consider community to be "a socially constructed notion intended to lend meaning to experience" (p. 51). Drawing on Potter and Wetherell specifically their 'interpretative repertoire' - they suggest that the term 'construction' is a particularly relevant and useful term as it creates analogies between physical components of building and language/meaning: the 'materials' of discursive construction are selectively chosen from pre-existing 'building blocks' and assembled to produce material and powerful effects (ibid., p. 52). Similarly, Liepins (2004) uses a framework to "read 'community' as both a discursive and material phenomenon of social connection and diversity" (p. 327). This framework focuses on how meaning of community is complex and socially constructed - people create community for a variety of reasons constituting various historical and political motivations, only the most superficial of which is produced simply by familiar human interaction in shared public spaces within a setting of daily routines. Creating communities is not merely a process of engaging with a preexisting entity called community, of which individuals simply have to claim membership. Community is not a fixed thing; it is a process - a process of becoming.

\subsubsection{Performativity: The process of becoming community subjects.}

Poststructural theorizing questions understandings of community as a fixed and stable category open to understanding by all inquiring minds, positing rather that community is a dynamic and contingent process (Butler, 1992). Community does not simply exist in a static form; neither is there only one community in, for example, Old Ottawa South. There are multiple communities being performed constantly, in an ever-evolving process. Several participants were involved in contested development projects in Old Ottawa 
South and in so doing performed a particular identity. Kurt provides an illustrative example of how individuals become resubjectified, their identities continuously shift (Butler, 1992), and they claim or reject membership in particular communities. Kurt explains the process of his becoming part of a community that became shaped by a particular identity:

I had lived in this neighbourhood for ... [from] seventy-eight to ... ninety-five, without getting involved in anything. And the two things that changed was first, I got a dog, and second, I had a ... you, know, our son was born. So, having a dog in this community immediately put you into the ... you know, connects you with all kinds of people across the community and then most of them tend to be very involved in the community. And having a kid puts you in the schools system, where you meet others.

Becoming part of a community for Kurt included to some extent interacting with others in shared spaces, but surely he had been doing this for the nearly twenty years previous to his 'getting involved'. In another part of the interview, Kurt describes how he never used to have a car but walked to everything, noting that this was possible in Old Ottawa South as it used to have many nearby amenities that allowed for one to live quite comfortably without a car. This daily interaction with other people is one type of community that included a particular shared identity. However, the change in identity that Kurt describes when he 'became involved' points to a different type of community. Kurt became a dog owner, self-identifying as one of a group of dog owners that uses certain parks (there are at least two parks in OOS that have their regular dog-walkers) and became involved in particular events, such as an annual park clean-up. He also became a parent and selfidentified with those involved with the school board at St. Margaret Mary School and who were involved in particular practices based on this identity. 


\subsubsection{Becoming an activist in Old Ottawa South.}

Kurt describes another process of becoming that contributed significantly to a particular identity in Old Ottawa South: that of activist. Although he never considered himself to be a political activist, he became one when the Ottawa Catholic School Board closed St. Margaret Mary's School; he then joined the fight to save the school and when that failed, continued to fight to retain the site as public space. Interestingly, Kurt notes that the 'activist' community is not homogenous. Having the identity of 'activist' is itself contingent and one of multiple possible identities that continue to be reformulated and reworked. Kurt self-identifies as being a particular kind of activist:

I had committee meetings ... to save the school, torn apart, because some people did not want to see any compromise, and ... there's going to be ... there's going to be people like that in any community that cares passionately about itself ... I guess I'm a bit of a peacemaker and a bridgebuilder ... I still maintain contact with these people and still say 'hi' and chat on the streets. (Kurt)

Being an activist may be constitutive of a particular identity but cannot be limited to binaries such as for/against a particular development or process. There are many ways of performing the role of activist. Even within the differences that Kurt describes, he also constructs categories of activist that overlook the contingent nature of community identity, and particularly, that of community activist:

... I think you've got to understand that there's not going to be a consensus. ${ }^{40}$ The people ... the people who lived adjacent to ... to St. Margaret Mary's School ... there was a few of them who ... would not have agreed with a position that would

\footnotetext{
${ }^{40}$ An interesting point to note (but beyond the scope of this thesis) is the different perspective of Kurt, an individual 'member' of Old Ottawa South, and Councillor Doucet on the role of consensus. According to Doucet, it is a rare exception where communities cannot reach consensus, which is needed in order to move forward, especially at City Hall. According to Kurt, among activists, consensus is highly unlikely: people often disagree and there is no swaying their opinions. Moving forward essentially results in some people winning and some losing, which is not consensus where, according to Doucet (interview), some people "have to take water in their wine" but they compromise and move forward.
} 
have put a ... put anything other than a development there. And there are people ... you know there are some activists in this neighbourhood who ... who are incapable of reaching a compromise position, so on the other side ... they have their vision of what it should be and ... and anybody who strays from vision is part of the enemy. It's sort of like the Trotskyites of neighbourhood community activists. (Kurt)

One of the challenges to both this research and to those charged with the political task of urban governance, it to resist the tendency to stereotype individuals and organizations based on preconceived and simplistic perceptions of what they represent. In the above interview statement, Kurt describes his own trajectory of becoming an activist, noting the complex motivations and incremental processes that led to his becoming an activist, while at the same time dismissing other activists that to him adopt an intolerant, radical approach. Similarly, Kate describes residents of Old Ottawa South within categories around socio-economic status and age:

... the people who are here - I think I saw statistics at one point - are generally, by age, older than the residents of the Glebe, and there's more people who own residences, rather than rent. So they're very well established, in their middle years, they've got a lot of resources, time on their hands ${ }^{41}$ to worry about political issues, money ... to prevent other people from coming into the community and to make a stance here and make it their community.

This rather unflattering description of Old Ottawa South residents describes a particular identity, perhaps useful to those who wish to undermine the whole by applying a category that may describe a small segment. Within a critical (and ironic) discussion of postmodernism, Butler (1992) notes, "a number of positions are ascribed to postmodernism, as if it were the kind of thing that could be the bearer of a set of

\footnotetext{
${ }^{41}$ Interestingly, through participant observation and interviews, several individuals (including one member of OSWatch) noted that the people who seem to get involved in organizations and committees, such as OSCA, tend to be those that are already busy with work, raising children, and other activities, and who keep getting involved despite busy schedules.
} 
positions" (p. 4). Placing a wide variety of positions under the unifying category 'postmodernism', results in the "violent reduction of the field to the one piece of text the critic is willing to read" (ibid., p. 5). When Kate makes the above description of Old Ottawa South residents, she is in effect reducing Old Ottawa South 'violently' to this one category of description that serves to represent the entire population (although to be fair to Kate, she notes elsewhere in the interview that there are many communities within Old Ottawa South, not just one; the above statement is her interpretation of a statistical description of Old Ottawa South, contrasted specifically with the Glebe).

Butler (1990) explains that attempts to understand subjects as categories for the purposes of representation is a political process that seeks to privilege, legitimate, and create assumptions about those categories (and by so doing make invisible and undermine other understandings). She also warns that "identity categories are never merely descriptive, but always normative, and as such, exclusionary" (Butler, 1992, pp. 15-16). Yet individuals are often part of a political process and use identity categories to position themselves vis-à-vis government policy and practice; decisions made at the municipal or provincial scales, for example, often have practical implications for people in terms of their lived urban experience and their ability to influence their own urban environments. In Old Ottawa South, one facet of community identity that often emerges is the construction of an urban identity that relies to a large extent on discourses of heritage, drawing on symbols and practicalities around notions of downtown or central, liveable, walkable, and sustainable; all of these notions draw on, to some extent, a romanticized view of the past - as superior to what the present has to offer. 


\subsection{Negotiating Identity}

In Old Ottawa South, tensions exist between community actors that struggle to maintain a particular urban form and those that insist on not being 'stuck in the past'. These actors form their identities based on very particular engagements with sustainability and heritage. As discussed in Chapter 4, many individuals question intensification as a sustainability tool, demanding instead more holistic notions of sustainability that draw on notions of community, identity, and heritage. Some individuals value particular heritage elements, such as front porches, or particular urban forms that facilitate pedestrianism. Many individuals reject heritage elements that perhaps might have heritage significance to others (e.g., a history of gas stations on Bank Street) if they are seen to conflict with the aforementioned 'neighbourhood identity' (although categories of identity are shifting, contingent, and contested). ${ }^{42}$ Several respondents question the need for increased urban density at the expense of 'nature' while others insist that greater density 'creates' community and conserves resources. For many, identity is wrapped up with notions of symbolism, even while these symbolic elements have material manifestations.

\footnotetext{
${ }^{42}$ OSWatch, the planning and development subcommittee of OSCA (of which I am a member), is currently involved in a project investigating why Bank Street in Old Ottawa South seems to be stagnating in terms of commercial viability. Some OSWatch members and individuals in the broader community consistently draw on a view to the past that privileges a time period around the 1920s, when the streetcar was active and Old Ottawa South was perhaps more reminiscent of a village than a city suburb, rather than a more recent history around the 1950s and 1960s, when gas stations and car dealerships were numerous. Yet throughout the process of participant observation and interviewing, I found that many residents fondly recall a $1950 \mathrm{~s}$ and 1960s Ottawa South (it was not labelled 'Old' until the 1990s), including the great service they received from Roy Barber (the local mechanic) and Lewis Motors (the local car dealership), not to mention the convenience of the drive-thru drycleaner and numerous gas stations.
} 
Participants' references to the physical boundaries and size of Old Ottawa South, its heritage as a neighbourhood of porches and trees, and its identity as an older 'downtown' neighbourhood (recall Section 4.2) allude to a symbolic role of the urban landscape as a physical site of community. While most participants doubt that a strictly spatially defined configuration creates or enables community, these physical attributes nevertheless have symbolic significance in the social production of community, identity, and heritage. Two participants also refer to the front porch as symbolic of community:

... people need to sit on their front porches and know who their neighbours are ... in terms of a neighbourhood it is a front porch community. There are people, you know, even when I walk to my car ... there's people I know in this neighbourhood: I've known them for years and years; and ... or say 'hello' to the same people, or we've seen their kids grow up. (Beth, female business owner in her 50s).

... that's another issue with what's going on in Old Ottawa South is there's a lot of ... the new design is alienation. The houses have got garages at the street level instead of porches and front doors and windows. People aren't sitting on their front steps because they don't really have enough room for them to do that. (Caroline)

Beth connects the front porch with social interaction, while Caroline views the loss as the front porch as symbolic of community decline.

\subsubsection{The front porch as material/symbolic.}

Several participants referred to the front porch when discussing community in Old Ottawa South. One participant expressed scepticism that the front porch has anything to do with community, noting that in her experience people do not use their front porch.

Despite their disuse, other participants view the front porch as symbolic of a built form and a way of life that has defined the neighbourhood historically and still contributes to its identity. The front porch, notes Caroline, represents community, interaction, and a 
transition between private and public space, even if it is not necessarily used for these purposes. An extensive popular literature credits the front porch with a variety of qualities (some material, some symbolic) that serve to create community. For example, the front porch prior to World War II, suggests Jackson (1985), was "the physical expression of neighborliness and community" (p. 280). ${ }^{43}$ Demolishing or filling in the front porch, according to Caroline, is like tearing apart community identity; building without front porches is replacing an identity or trying to impose a new identity:

... what I've noticed, especially over the last five or six years, is the deterioration in a feature that is not unique to Old Ottawa South ... or wasn't unique to Old Ottawa South but is ... potentially almost unique, is that it's a healthy community based on a front porch life. And ... those front porches are disappearing very quickly ... through rebuilding, through people infilling their porches, through maximizing density, which means that people get rid of the porch, 'cause your porch counts. Like, your porch counts as part of your property ... it helps define the boundary of your build-able area. And so people want to have large space inside their houses, so they're building without porches. A lot of new houses have no porches. And one of the difficulties of that is it obscures the ability to see down the street from sitting on your porch. And I think ... this was a way of life and our neighbourhood is one of the few that still has that; extensively has it. So, I'd say it's a historic feature that is disappearing really quickly ... often under arguments of sustainability by the way [laughs] ... they fill in the porch; they create vestibules, and they're looking at it from the point of view of one house, as opposed to the line of houses: the streetscape.

Caroline refers to the streetscape as a feature that connects houses, which on their own would be individual units but when combined gives them a larger identity. For Caroline, the front porch literally and symbolically reformulates the urban landscape from an embodiment of individualism towards a site of community and communalism.

\footnotetext{
${ }^{43}$ Jackson's (1985) discussion of the front porch as symbolic of community is peripheral to his hypothesis that the automobile (followed by air conditioning) at the very least coincided and perhaps facilitated the general demise of community in American towns and cities, resulting in a "general withdrawal into selfpursuit and privatism" (p. 280-281).
} 
Furthermore, Caroline interprets the front porch as a symbol of heritage that contributes to the identity of Old Ottawa South. Infill development that undermines this heritage, according to Caroline, influences the sustainability of Old Ottawa South:

... the way the city's rules work is everybody's building garages; they're building garages at the street level; that means their porches are either high up or not there ... there's a lack of relationship with the street but from a purely environmental sustainability issue, I would say it's also changing the appearance of the neighbourhood and its removing trees that could be used as an alternative to heavily sealed [laughs] houses.

Thus the identity of Old Ottawa South is changing as it loses more and more of its older homes and trees, which were part of a system that worked well for years and became symbolic, comforting, and part of the identity of those living there. Kate challenges the notion that things should remain the same simply because they are comfortable, but rather calls for residents to "not be stuck by ideal ... you know, they did it a hundred years ago it's good enough for me." Beth notes that the front porch symbolism can also be applied to this sense of being stuck in the past, particularly in the discussion around urban sustainability and urban vitality: "in terms of sustainability ... there has to be an ebb and flow to it, in a way. There has to be an intake and an output ... you can't, sort of, have the same people sitting on their porches, [saying] exactly the same thing, to the same other people every day and expect there to be any vitality." Despite Caroline's mournful loss of the front porch, she maintains that there is an important difference between being unwilling to change and being wary that not all change is positive:

I do not get the sense people are afraid of the future ... people are comfortable with the spaces they have; they're comfortable with the physical relationships that they experience on a day to day basis, and they look at new design and new development and realize that things are going to change and they're naturally and reasonably wary that it's not going to be as good as what they have now. 
Many participants accept that change could be a positive force within an urban setting and that processes of change need not be incongruous with heritage and community identity. Hugh in particular engaged in notions of connectedness with the past within processes of renewal:

... if you've ever been in an old building where, you know, they've got old stone steps, and you walk up the steps and you can feel how the steps are worn by, you know, people's feet who have gone ... over and over, there's a sort of sense of ... connectedness and that ... I think that's important. It's not to say, though, that neighbourhoods ... everything is going to change ... cities and places reinventing themselves ... I think that, you know, you just have to go about stuff sensitively.

For Hugh, heritage is important and is part of the dynamic process through which urban communities locate the past within the present: in this sense, heritage is part of a continually evolving identity that cannot but change. Heritage is not about staying the same - it is about connecting selectively with the past while embracing the inevitability of (preferably balanced and respectful) change.

\subsubsection{Identity and collective heritage.}

The contested development of 88 Bellwood drew to some extent on discourses of heritage. In their work with Crofters in Scotland, Mackenzie, MacAskill, Munro, and Seki (2004) explain how discourses of 'collective heritage' are used to claim a collective right to land that had become part of the community identity of crofters, who had historically worked land that was an integral part of their everyday lives. This right is not simply a claim to the material existence of the land, but, according to Mackenzie et al. (2004), collective rights are about "the politics of the land, as a material resource, and the 
poetics of the land, as a symbolic resource, [which] are bound up in the negotiation of identity" (p. 160). Emily is part of a group of present and former Old Ottawa South residents who claimed 88 Bellwood as part of their collective heritage and their community identity, both in material and symbolic terms. Emily grew up in Old Ottawa South and is familiar with those who built the school; she also attended the school and had children who subsequently attended the school. Not only is 88 Bellwood part of her heritage, but also she claimed a right to the building and the land as public space, which she (and others who made similar claims) had used for over 70 years. According to Emily, the Catholic community in Ottawa South purchased the land in the 1930s and paid taxes on the property for over 70 years. For Emily and others, the school and the land it occupied formed a meaningful part of their identity.

Collective heritage is consistent with what Tweed and Sutherland (2007) refer to as "[h] eritage by appropriation [that] emerges from public behaviour ... [and] acquires its status through use rather than through deliberate consideration" (p. 63). This form of heritage is a departure from institutional practices that privilege architectural or other historical 'significance', officially designate significant examples of buildings as 'heritage', and then protect them from demolition or alteration. 'Heritage by appropriation' and 'collective heritage' refer to those aspects of a community that are deemed important, not necessarily for their 'intrinsic' value or the value placed on them by 'experts', but rather due to their contribution to an individual's or community's sense of identity (Tweed \& Sutherland, 2007). 
As Lillian relates, however, historical use of 88 Bellwood (the school, the surrounding playground, or the urban landscape of which 88 Bellwood is a part) is not required to claim the space as integral to one's identity. She recalls how even very small children (including those that did not go to the school) had visceral responses to the demolition of the school, as a part of their urban landscape was being violently uprooted. For these children, the school had meaning, not as heritage, but as a familiar part of their environment:

... it's very complex how people respond to their environment and changes in it, and what ... they mean to people and you know, how much people want to ... have certain stability in parts of their environment and, you know, it's kind of identity and home ... I think it can go from that, where ... there isn't really a history; there isn't a ... you know there isn't a narrative history, there isn't like, a series of events that produced experience, like you went to that school fifty years ago, you know, it's just sort of ... it's just a ... it's very much of the physical environment and how people are so attached to their physical environment, you know. So you see that kids when they don't have the... 'cause with older people, like some of the folks ... like [name of neighbour] down the street, she went to the school and my dad went to the school and I knew different people who went there in the nineteen forty's, and ... you know, it'd be heritage for them because they knew the history. They knew what had happened. They knew who was there. They, you know ... they knew all the stories. And the stories were long and sustaining. And so it would mean ... it would be heritage for them because it had this certain historical perspective, but ... I guess what I'm trying to say is the importance of something near you, and it isn't limited to that historicity. (Lillian)

For some, St Margaret Mary's school was significant within a historical context that contributed to a collective heritage. For others, it was not the school or its history that was important - it was the public space, the urban landscape, and the sense of belonging and home that the space instilled as part of their identity. Individuals relate to their urban environment in complex ways and the urban environment contributes to their identities; changes to this environment are sometimes perceived as threat. 


\subsubsection{Change as threat.}

As I write this, at least three residential developments are in various stages of construction in Old Ottawa South (with several others recently completed and many others the subject of much speculation and unease, especially by those individuals involved with current or previous contested developments); all have been met with varying degrees of disapproval from neighbouring residents who perceive these developments as a threat to their urban environments and their collective identity. The three contested development projects on which this thesis draws seem to be merely the leading edge of an increasing number of what residents consider inappropriate development - inappropriate to the point where some consider it an invasion of the neighbourhood: of profiting from the neighbourhood without having regard for its wellbeing over a longer time frame. ${ }^{44}$ These residents draw on what Mackenzie (2001) refers to as a 'colonizing discourse' that serves to legitimate a form of intrusion for the purposes of corporate capitalization, by privileging private property rights at the expense of collective rights, and (in the context of urban intensification) through the language and practice of sustainable development.

\footnotetext{
${ }^{44}$ During a community meeting about the proposed redevelopment of 71 Hopewell, one resident used the term 'outsider' to describe the developer, in the sense that he would buy a property in the neighbourhood, develop it to make a profit, and then leave the neighbourhood without retaining any form of responsibility for the development. Dalby and Mackenzie (1997) contrast community identity with the 'modernist project' of corporate, economic 'progress'. Similarly, during the 71 Hopewell meeting, the developer argued on the economic merits of his proposal, stating that his buildings are what clients want (i.e., will pay more for) and that he would be employing dozens of construction trades, thereby contributing to Ottawa's economy. The resident attendees of the meeting burst into laughter at this point, bemused/outraged that these modernist, neoliberal arguments were being used in an attempt to mitigate the effects of a massively scaled building that these neighbours perceived as a threat to their identity.
} 
Individual developments that neighbours consider out of scale perhaps only threaten individual neighbourhoods (or small portions of them). As the frequency of these developments increases, and as 'inappropriate' infill becomes a topic of broader community concern, the threat shifts in scale from that of individual to that of community; this perceived threat not only mobilizes the community to increase their awareness of further potential threats, but it also 'creates' community by reinforcing and making new an identity that perceives its community in a certain way and has common ground with which to fight the invasion of inappropriate infill development.

Attempts to prevent inappropriate development has led Old Ottawa South residents to redefine their identity, including the collective identity of the neighbourhood as a 'front porch' community, with ample greenspace in front and backyards, where 'suburban' forms, such as large houses and garage-dominated facades, are criticized and shunned (except by those who buy the properties and consider these features to be amenities). The creation of a community identity, according to Dalby and Mackenzie (1997), "frequently relies on mobilisation around a set of symbols which, rather than expressing any inherent meaning of community, provide the means whereby people 'make meanings'" (p. 102). Furthermore, by engaging strategically with these symbols and drawing on an idealized view of how things once were (e.g., front porch, particular architecture, certain housing density) individuals create community as unified and homogenous, overlooking differences in order to provide a more effective political opposition to the threat of 'inappropriate' development (ibid.). Communities use the ambiguity of symbols to express themselves outwardly as unified, while maintaining 
internal difference vis-à-vis the meaning and significance of these symbols (ibid.). It thus becomes possible for the 'community' of Old Ottawa South to inform their ward councillor, city planners, and incoming developers what urban experience they value and with what built form it should be manifested, even though the various residents do not necessarily agree on the precise meaning of the symbols constitutive of particular identities. In some cases, the community association can become the voice of this unified community - it can become an "outward expression of commonality" (ibid.) as long as internal difference remains a possibility.

The neighbours of 35 Brighton created particular aspects of community identity by drawing on a number of imprecise but effective symbols revolving around 'sense of place' and 'neighbourhood character':

The homes on Brighton Avenue and in our neighborhood are generally older, with welcoming entranceways, front gardens, front porches and with mature trees lining the street. While the yards are small compared to suburban lots, residents have landscaped to maximize greenspace. All of this encourages the friendly interaction between neighbours and makes our neighborhood so vibrant and desirable. (Ostling, 2008a)

The author of this statement mobilized the perceived threat to 'sense of place' and 'neighbourhood character' produced by the redevelopment of 35 Brighton to create a position that could be accepted by most residents as a commonality. Neighbours of 35 Brighton then used this commonality to organize a petition and strategically reinforced their position by appealing to the community association, OSCA, for endorsement. As such, the creation of community in this case drew on symbols to strengthen a position of neighbourhood homogeneity; the petitioners further politicized this position by publishing an article in The Oscar. In addition, by having their petition endorsed by 
OSCA (with which the ward councillor Clive Doucet is deeply involved), the petitioners broadened the scale of this identity to the level of City Council. Renita, a female member of OSCA in her 60s, explains the political motivations for individuals to seek support from the community association and the Ward Councillor:

... the neighbours were up in arms about the way this thing was going to look and, you know, they went and had a little committee, came to OSCA and asked for our endorsement, and so we said 'yah, ok'. But that's why they ask for our endorsement, is, because if they can ally themselves with us, it seems like a bigger ... it has bigger impact because it seems that we speak with a bigger voice. And in some ways we do, because of the way it's structured. But that's also perhaps why, you know, you ask for the councillor's endorsement of the various issues is because he's the next level up from us. There isn't anybody else in between, and he's actually a decision-maker so why wouldn't you go and ask for his endorsement.

Councillor Doucet feels compelled to support what he perceives to be a unified community voice, and thus in the case of 35 Brighton, OSCA became a mechanism through which a particular community identity became visible to the outside (the media, the developer, city planners) in order to protest the perceived threat of 'inappropriate' development.

\subsubsection{Beyond representation: The politics of community associations.}

The visible manifestation of community is not the same as representation of community: positing that OSCA can become the visible manifestation of a particular community identity does not mean that OSCA represents that identity, since, as mentioned earlier, this visible identity masks internal difference. Renita provides an illustrative response to a particular identity based around heritage aspects of Old Ottawa South's built form, noting that this identity means very little to her: 
... I didn't grow up here and I'm not attached to that view of what a community should be. I have had other experiences in my life. I did ... I've lived in other kinds of places that had ... different looks to them ... and who think of other things as being important. So I'm not emotionally attached to that, to that way of looking at things.

Renita does not include the particular material or symbolic heritage and built form that is common in Old Ottawa South as part of her identity. However, as a member of OSCA, she was nevertheless part of the visible manifestation of community that neighbours of 35 Brighton used to more strongly argue their case to the next level of government. But Renita is not represented by this identity, and others are certainly excluded as well. Interview participants struggled with the idea of representation; no participant clearly accepted that OSCA represents Old Ottawa South, although according to Guy, OSCA, together with the community newspaper The Oscar, represents Old Ottawa South better than any other political body:

In Old Ottawa South, they would like to represent the community as best they can, and I guess the main tool that they have for that ... they don't have votes or anything like that but ... the transparency of their own proceedings ... when they're taking a strong position, on a problem, they 'talk' about it in Oscar. It's sooner or later in the community newspaper. So if anybody doesn't pipe up then and say, 'no, no, no, please don't go that way,' then that's the way the community is going to go. And ... that's as good a model of governance as you're gonna get in a community association. Because it's a very powerful ... newspaper. It really reaches every house and it is really thick enough to have, you know, substantive stuff in it. And, that's real good. Lots of other communities don't have a paper that good; they don't have an association that actually puts their stuff into the paper; they have ... they're missing one of those cogs, and I think that's ... pretty good.

For Guy, the openness and wide distribution of OSCA proceedings and the ability of individuals to get involved provide the best form of 'representation' that a community can reasonably expect to have. Renita describes community associations like OSCA not as representative bodies, but as mechanisms through which individuals can 'speak' to higher 
levels of government; for her, OSCA "is meant to be a conduit for information ... back and forth. There is no structure for citizens to make their voice known here other than at election time." However, the role 'conduit of information' is one that can quite quickly turn into that of 'representative'. Conduit suggests a vertical structure, or silo, in which individuals have little agency on their own and must go through the 'appropriate' channels in order to influence governance.

This view of the community association, and the need to appeal to progressively more important political structures in order to influence change, contrasts with Darryl's assertion that one needs to act at a very personal and local level in order to produce results in a meaningful way: "the way is to make it small, but in order to make it small and make it work, you have to affect a larger ... a larger arena, a larger sphere of influence." For Darryl, one does not merely act locally - it is not simply a matter of acting locally and thinking globally - but rather the best way to get the most from one's efforts is to act in very small ways - perhaps initiated by a few individuals - but in ways that necessarily have broader implications. Furthermore, Darryl feels that bold pronouncements have little impact if they do not have very personal repercussions recognisable at a meaningful scale influencing people's everyday lives.

Both Darryl and Emily are quite critical of OSCA. Their experiences left them feeling that OSCA was not well attuned to individuals within the neighbourhood. Darryl feels that The Oscar is more important than OSCA because as a community newspaper, The Oscar is accessible to all and anyone can contribute their opinions, whereas "OSCA isn't as representative as it thinks it is" (Darryl). Similarly, Kurt values The Oscar as a 
community building tool - more so than OSCA - particularly for those who are not involved in OSCA: "Oscar, the newspaper, is probably more important than OSCA, the community association, in creating that sense of community for many people ... certainly in my sense of the community, before I became involved in local activism, was shaped by Oscar." Membership requires and produces a certain way of being; The Oscar, by contrast, is intended to reach all residents of Old Ottawa South and does not require a specific identity or privilege particular positions in order for individuals to access it.

Emily, who was involved in the fight to save St. Margaret Mary's School at 88 Bellwood, feels that OSCA was not really aware of how individuals in the community felt about the proposed redevelopment, compared with volunteers who petitioned the neighbourhood and talked to individuals 'on the streets' (as opposed to at formal community meetings): "we're knocking on doors so we know what they're saying" (Emily). And it was not simply because OSCA was not informed, but according to Emily, OSCA had other priorities, such as renovating the community centre, and did not want to jeopardize this by taking a strong stance on 88 Bellwood: "I don't think [they] have any idea about how people in the community feel about this issue ... not that we hadn't spoken, spoken, and spoken to them, but they had an alternate vision." For Emily, political motivations undermined community concerns; in this context, OSCA was not particularly interested in trying to represent the community; it prioritized more internal goals at the expense of the broader community (although many OSCA members would no doubt argue that their goals were prioritized for the sake of the community, even if the community did not realize it). 
Kurt struggles with the idea of representation, providing complexity to

community identity as something that is shifting and contingent:

... does OSCA represent the community? I ... I'd have to say so. I mean it was ... you took an issue like ... like Lansdowne Park. OSCA's now come out very strong in opposition to the Lansdowne Live proposal. I know that there's many people in this community who do not agree with OSCA on it. They ... how are they going to express their views? Well, I guess they could ... you know ... Greenberg - Roger Greenberg was on the radio this morning talking about what he referred to as the silent majority. There may be a silent majority in this community that would agree with Lansdowne Live - I'm not sure there is ... Roger Greenberg was also saying how the people at a lot of these public meetings who agree with him would just sort of come up to him and say it quietly. They're not about to stand up on a soapbox the way that the activists and the people who are accustomed to working for the community association. So, you know, I seem to be talking myself into the opposing position I began with. And that would say that OSCA may not represent the community but it certainly represents the ... the people who want to ... the community activists. ${ }^{45}$

OSCA may represent some component of the community some of the time. Kurt recognizes that OSCA may at times represent specific community identities, especially those of activist, if activists can garner the support of the community association by drawing on symbols that "present a front of homogeneity vis-à-vis the other" (Dalby \& Mackenzie, 1997, p. 102). But Kurt also refers to a 'silent majority', who may 'represent' hidden forms of community: claims to a common purpose may mask difference. Dalby and Mackenzie (1997), drawing on the work of Foucault, charge researchers to analyze critically how and for whom visible community identities are constructed, with a view to

\footnotetext{
${ }^{45}$ I took a special interest in Kurt's response, particularly in the way he changed it and worked through it in conversation. I consider this a distinctive 'research moment' - an excellent example of the complexity of respondent statements, and a particularly useful attribute of the semi-structured, indepth interview: it gives respondents time and opportunity to change their positions, and it allows the researcher an ability to clarify or engage more fully in a topic that a less conversational, less open-ended method could achieve.
} 
recognizing oppositional discourses that challenge particular discourses of community discourses of community that are strengthened by symbols that serve to unite, resulting in some individuals claiming membership by drawing on these dominant discourses, and in others being excluded from membership (through silence or silencing).

For City Councillors and community associations, categorizing community in particular ways and making claims of representation are processes that they consider empowering in order to achieve certain political goals. When OSCA claims to represent Old Ottawa South and portrays its decisions as reflecting the desires of the community, it is usually doing so politically, to achieve specific ends. For example, when OSCA presented at a meeting during public 'consultations' for Lansdowne Park (Jenkin \& McCoy, 2009), OSCA perceived a need to claim representation of Old Ottawa South to more powerfully argue its position against the redevelopment of Lansdowne Park, even though, as suggested by Kurt, it is quite unlikely that all residents of Old Ottawa South oppose the redevelopment of Lansdowne Park. Councillor Doucet (interview) feels that he needs unified claims of representation to make any progress for Old Ottawa South at City Hall:

... if you can't find consensus among yourselves about how to go forward on any issue, don't come to me because I cannot sell this at council. I am one councillor out of twenty-three and if there is any indication that the community is not ninetyfive percent behind you, forget it, there's no point, you'll just basically be wasting everybody's time, and worse that wasting time, being destructive, you know like ahh, when the community falls apart over an issue sometimes, often going forward is put back twenty years.

The perceived need for representation seems to be connected to the selling of ideas, rather than trying to achieve what is best for, and desired by, particular communities. 
Butler (1992) notes that politics often claims to need foundations - it relies on the perceived ability to understand subjects and their positions. Yet adherence to strict categories of community tends to disempower those for whom community is performed in other ways. Butler (1990, p. xxiii) would have us ask the questions: "What is community? How is it produced and reproduced? What are its possibilities?" In other words, community is shifting and contingent. Identities are being reworked constantly, always engaged in the process of becoming something else. Addressing Butler's questions leads us quickly to a critical analysis of the ways in which community is currently understood by policy makers and used for political purposes to impose particular policies on neighbourhoods such as Old Ottawa South. Disturbing the existence of the category 'community' also explicitly calls into question the structure and scale of municipal politics in Ottawa, as it becomes clear that municipal decision-making fails to account for the discursive construction of community and the processes of community identities that operate outside of those categories that municipal governments recognize and privilege. It is not simply a failure to recognize or account for other ways of being. Particular constructions of community that are considered to be the norm are used to dismiss and de-legitimate alternative community identities and practices. But these alternatives do exist and are often made visible when community is threatened. Each time another redevelopment is proposed that is perceived by some to be damaging to the neighbourhood, a new group of activists is formed and identities are reworked as they become more engaged. 
Against these newly formed/forming constructions of identity are those that contest and attempt to resist such 'activism'. Particularly within the capitalist enterprise that is urban development, constructions of community that are deemed incompatible with dominant discourses of growth are dismissed as radical, NIMBY, or unrealistic. A supporter of the 88 Bellwood redevelopment illustrates well the dismissal of a particular construction of how urban land should be used in Old Ottawa South:

My concern is not with the rezoning itself, with which I have no objection. I am writing to express my discontent with some of my fellow residents who have organized a campaign to interfere with the rezoning. A small number of residents in the area have been persuading members of our community to rally against the rezoning through the use of misinformation and disingenuous promises. A great number of people have been convinced to sign a petition opposing the rezoning under the false hope that this property will be used as a school facility or for a community centre. (Ottawa, 2005c, p. 23)

In this quotation, efforts to defend a particular community identity are dismissed as interference conducted within a framework of false hope. The author of this statement draws on a particular construction of community and land, where municipal planning tools and development processes are portrayed as common sense but where community interference with these processes is seen as inappropriate and incapable of being legitimate in its cause or accurate in its arguments. By constructing activism as interference, not only is the work of these activists discredited, but also those who have been 'persuaded' are portrayed as foolish to be hopeful about their abilities to influence development processes. But activism against perceived injustice versus the normalized municipal processes that enable redevelopment and neighbourhood change are not simply tensions within communities, mobilized occasionally as contested development projects 
arise. They are inculcated within the broader discursive strains - fed by a salvo of urban 'renewal' projects - that render sustainability and growth incompatible. As these tensions make their way to the level of communities and individuals, these communities and individuals resist what they perceive as threat to their urban space and their way of life indeed their urban identities.

\subsection{Sustainability as Threat}

I argue in Chapter 4 that hegemonic discourses of sustainability in Ottawa, particularly evident in the official plan, largely ignore community and instead focus on such things as economic efficiencies and natural resource conservation, through 'sustainability' initiatives such as Smart Growth and urban intensification. Yet interview participants draw on alternative discourses that see community and sustainability as linked and central to sustainable urbanism. Furthermore, in Old Ottawa South, residents often mobilize discourses of community and heritage to contest developments that are legitimated by discourses of intensification and Smart Growth. As communities claiming specific identities contest particular forms of urban development, two key and related themes emerge: that of urban development based on a market system that privileges capitalist accumulation; and that of the role of individualism that privileges private property rights over those of the collective. It is difficult for communities to successfully argue that a particular identity is under threat and should be protected when these notions are pitted against dominant discourses and practices of growth and private property rights. 


\subsubsection{Urban development as a capitalist enterprise.}

Several interview participants seemed uneasy about criticizing development and specifically explained that they were not preservationist. For example, Guy, discussing the importance of heritage, notes: "you don't have to be stuck in it at all. You can develop tremendously. But within the notion of preserving the $\ldots$ the history of the community and the institutions in it." Not all change is perceived as threat to identity; most participants see change as an inevitable (and often desirable) process. For Beth, change is an essential part of sustainability:

I think sustainability has to be ... like a monoculture doesn't work, although that ... for a certain period of time gives people a level of comfort. It's kind of like agriculture where, well yah, you can grow the same thing over and over and over again, and keep dumping the same pesticides and nutrients into the soil over and over and over again. But when there's a break in that you end up with ... no vitality. So it's ... and I mean this half jokingly, and maybe it's kind of like an old Star Trek episode, where, you know, these people live in this little bubble on a planet and they've sort of sustained the same thing and the same sense of comfort over and over and over again, because there's actually nothing - no place to grow, or nothing else to do, or no vision, or ... everything else is inhospitable, either to, you know, their life or their ideas. And so you come into this from the outside and you go, 'what the hell is going on here?' Because it's actually, like in a vacuum, and that with any kind of encroachment or any change or any alternation from the outside, it falls apart.

This response is completely removed from land-use initiatives around sustainability and intensification; it focuses on societal processes of becoming and evolving. Furthermore, Beth is describing a static community that does not exist in reality: all communities change over time, even those that resist change in order to hold on to those aspects of built form and social interaction that provide stability and comfort. Using another Star Trek analogy later in the interview, Beth jokingly uses the phrase 'fear of contagion' to describe an overly preservationist and defensive fear of the outside and the unknown. 
However, Irene (Beth and Irene were interviewed together) posits that these communities are not necessarily being preservationist:

... sometimes, you know, in those episodes of Star Trek there's these lovely little communities, and maybe this is the other thing that could happen right? Is these nice little communities are going along, you know, and then they decide to ... you know, somebody drops in from outer space and sort of contaminates it.

According to Irene, communities can exist and evolve in a reasonable and balanced way but when developers sense that neighbourhoods are potentially profitable sites for development, they come in and develop with little regard for the people living there. Irene's response has parallels to a response given by Caroline about how modern homes change the way the neighbourhood functions:

The newer houses: they're all security conscious, so they want to keep their windows closed, so if you keep your windows closed you need air conditioning [laughs]. They don't have trees so they have no shading in the summer; they're using their air conditioning. Because they've got to listen to the noise of their air conditioning, they're not using their own front yards and people sitting on their porches have to listen to it. It's a ... vicious circle. It was a very nicely contained system and people have tinkered with the system, and in the tinkering the system's starting to break down. (Caroline)

Both Irene and Caroline refer to communities as relatively stable systems (although they may be complex and evolving at the same time) that are undermined by specific changes that have broad, often unforeseen effects. Irene is referring to rapid changes produced by the 'outside', as many developers are perceived, whereas the changes that Caroline alludes to are more incremental. A local resident, in an Oscar article, echoes concern for incremental changes that have cumulative effects, noting that although processes of urban change and renewal are dependent on various forms of redevelopment and change, recent changes are different: "there are some real changes which, collectively, are creating a 
much different place" (Hecht, 2010, p. 28). For Irene, Caroline, and Hecht (2010) current changes are not part of a process of becoming - of reinvention and renewal of community identity - but rather threat to community identity, enabled to a large degree by policies around intensification and dominant institutional discourses of sustainability that normalize and privilege developer-led growth, 'invasion', and capitalist accumulation.

\subsubsection{Private property rights and individualism.}

For many, including Jackson (1985), post World War II suburban sprawl and the advent of the automobile signalled a move towards individualism and 'privatism'. For Hecht (2010), one symbolic and practical manifestation of this automobile-centred individualism and the "suburbanization of our inner city streetscapes" (p. 28) is the garage-door-dominated streetscape that contemporary 'monster' infills and townhouses produce (recall Figure 1.4 in Chapter 1 for an example). This is a serious claim requiring a critical appraisal (although beyond the scope of this thesis).

Discussions on infill housing and intensification often draw on notions of private property and individualism, particularly within the comments section of online news articles. For example, Fagan (2010, May 21), reporting on a housing redevelopment (proposed demolition of one house and construction in its place of a larger house), generated 45 comments, which were fairly evenly divided between those who supported the development versus those who did not. Of the 45 comments, 11 mentioned private property rights, property values, or the right to enjoy one's property, using colourful phrases such as "this land is his land, back off government" and "bleeding heart leftists." One comment draws on notions of individualism, contrasting its effects with aspects of 
community and social engagement. This commenter stereotypes the proponent's attitude as: "me first to hell with everybody else," and suggests that this type of individual is responsible for "most of the urban intensification in trendy neighbourhoods like WW [refers to West Wellington or Wellington Village], Westboro, the Glebe, etc." The commenter continues with a synopsis of how a social breakdown leads to the destruction of neighbourhoods: "whatever happened to basic human decency to one another? ... these residents are exercising their right to protest the proposal. That's why they put the black and white signs outside new developments informing people when and where to voice their concerns." The juxtaposition between private property rights and the rights of individuals and communities to influence the process of urban development illustrates well the tensions that empower competing discourses of intensification and growth. This example of urban development is further complicated (one reason why I chose to use it) by the fact that it is not developer-led and cannot be explained simply by theorizing about 'cities for people, not for profit' (e.g., Brenner, Marcuse \& Mayer, 2009). For in the absence of 'for profit' one can still ask, "for whom is the city?" What is the role of rights, and why are property rights privileged over other forms of rights? Clearly, these questions lead to more questions and to a body of research that scholars (e.g., Harvey, 2003; Lefebvre, 1974/1991; Mitchell, 2003) have spent years developing. Yet these questions also serve to illustrate the complexity of such concepts as sustainability, community, and heritage, leaving the door open for critical debate around their implications, rather than accepting as dominant and unquestionable dominant discourses that seek to discipline subjects into particular ways of thinking and acting. 


\subsection{Towards an Identity of Possibility and Hope: Conclusions}

Chapter 5 attempts to place community in the space of possibility and hope. As this chapter shows, municipal policies in Ottawa do little to empower discourses of community, and reduce community, sustainability, and heritage to limiting categories that a municipal governing structure, composed of politicians and 'experts', is willing to engage; municipal governance around urban development privileges land-use planning and relies on models such as Smart Growth in order to carry on as usual - to make claims of creating community and sustainability, while concurrently enabling economic (and physical) growth. To conclude clearly what community should be, how individuals should 'properly' relate to their urban environment, what heritage they should claim, and what sustainability initiatives they should agree with and submit to, "would be only and always to produce a new site of political contest" (Butler, 1992, p. 16). Insisting that it not be so - that these notions must be decided once and for all and that contestation be refused or disempowered - is, according to Butler, to undermine the democratization of civil society itself. Smart Growth, urban intensification, land-use planning, indeed any form of normative policies and practices that politicians, planners, developers, etc. claim as authoritative and incontestable serves to undermine democracy by closing the door for public debate.

This chapter also shows that community identity is complex and that public debate surrounding community is (or at least should be) inevitable. Subjects continually construct and reconstruct their identities, often for historical, political, or practical reasons. They also do so when they perceive their identities to be under threat. Sections 
5.4 and 5.5 in particular illustrate how individuals and collectives of individuals often mobilize and 'create' anew community identities, as they respond to threat and contest threatening policies and practices. Politicizing identity often involves mobilizing a 'collective identity' that although masking internal difference (and thus being limiting and challenging) can serve as a tool (or weapon) for contestation.

Kurt provides an illustrative example of the juxtaposition between hope and despair, and the implications of each for community identity. Faced with the 'invasion' of townhouses at the expense of public space - an assault to the collective heritage and identity of many Old Ottawa South residents - Kurt could have despairingly bemoaned the loss of St. Margaret Mary's School and grown resentful of invading developers intent on ruining his neighbourhood. But he did not do this; he 'entertained hope' both during and after the fight to save the school and offered ways to welcome the new:

... it was my first experience with any of this, and so I tend to be a believer and that things would be done. And people with more experience, were commended by hard work but, you know, 'the reality ... you can continue fighting the fight but it's a done deal' ... I kept on believing that it was not a done deal ... we kept fighting for it.

... it's not the deal that I fought for, but it turned out to be ... it turned out to be ... a good deal. And ... it might even be a better deal because we fought, you know, because Charlesfort had to really come to the table with something ... you know, Charlesfort is a great developer, and this is ... the sense that I got is if we were going to have anybody develop that property, you wanted Charlesfort ... they came to the table with quite a beautiful vision of what that ... that street would become.

When I first heard Kurt say that the development at 88 Bellwood was a good deal, I was quite shocked and even somewhat disappointed. Most other participants were more negative about their experiences with this redevelopment and harbour resentment to this day (as do I to a certain extent). Yet Kurt did not seem resentful at all. Considering the 
amount of work involved in this contestation and considering the apparent assault to community that this development represents, Kurt was incredibly gracious and seemingly forgiving about the way the City of Ottawa enabled this redevelopment and about the way the Ottawa Catholic School Board profited by selling 'public space' to the private sector. How could Kurt then conclude that 88 Bellwood turned out to be a good deal?

Let me ponder this question and conclude the chapter with some preliminary musings 'permitted' by what Gibson-Graham (2006) characterizes as 'weak theory'. The author(s) suggests that theory can do a number of things, including broadening, extending, and confirming knowledge. But she also suggests that it can serve another purpose: "to help us see openings, to help us to find happiness, to provide a space of freedom and possibility ... [that is] practicing a 'weak' form of theory that cannot encompass the future" (p. 7-8). Within the context of urban neighbourhoods such as Old Ottawa South, weak theory cannot know the best way to 'create' community or what urban form should be enabled and privileged by municipal policies such as zoning changes and intensification targets. Weak theory fails to conclude what role capitalism will play on urban development; it is incapable of predicting that, according to a developer working on an infill on Hopewell Avenue (paraphrasing), "this is the future of the neighbourhood because this is what clients want." Nor can weak theory predict whether community activists will succeed or fail - or that they won't make a difference because those 'in the know' have said that a particular redevelopment is a 'done deal'. ${ }^{46}$

\footnotetext{
${ }^{46}$ At least three participants referred to 88 Bellwood as being a done deal from the beginning, as too much money was involved and the site was considered by law to be 'private property', as it was 'owned' by the Catholic School Board.
} 
Weak theory, suggests Gibson-Graham (2006), "can be undertaken with a reparative motive that welcomes surprise, entertains hope, makes connection, tolerates coexistence and offers care for the new" (p. 8). Furthermore, its goal is to wipe clean the slate of assumed power relationships by questioning the incontestable nature of structural arrangements that result in individuals acting in certain ways, or, for example, community associations relying on particular political best practices because these practices are entrenched and their disturbance leads to unknown and fearful trajectories. Although Kurt is not deluded about the negative consequences of the loss of community space in Old Ottawa South, or about perceived negative changes that increased urban redevelopment might bring, he is clearly 'tolerant of coexistence' within the context of reparation. This will certainly be a challenge to residents of Old Ottawa South in the future: to contest perceived threats and to force open the channels of public debate, while remaining hopeful, welcoming surprise, and tolerating coexistence. 


\section{Chapter 6: Conclusion}

Based on the insights generated throughout this thesis, Chapter 6 summarizes how certain discourses of sustainability in Ottawa have become dominant, particularly within the municipal government and the development industry. Section 6.1 reiterates the theoretical basis of this thesis drawing on various fields of thought, including political ecology, poststructural theorizing, and discourse analysis. It highlights the contributions of this thesis to these bodies of research and suggests additional theoretical avenues that could serve to further research around urban development and sustainability. Section 6.2 summarizes the results of empirical research based on a case study in Old Ottawa South. Section 6.3 highlights, by way of example, some practical limitations of, and challenges to, this research. Finally, Section 6.4 discusses contributions this research has made, and reflects upon processes of contesting dominant institutional discourses so that members of civil society can be more fully engaged in creating a more sustainable future.

\subsection{Theoretical (Anti)Foundations}

This thesis draws broadly on political ecology as a conceptual framework. It departs from current urban research on political ecology that adopts, to a large extent, a marxist historical materialist approach to understanding nature, capital, and the exploitation of nature within a capitalist market system (Castree, 2001; Heynan et al., 2006; Kaika, 2006; Keil, 2003). Instead, this thesis uses poststructural theorizing and Foucaultian discourse analysis to examine critically how the social construction of nature contributes to understandings around what counts as nature and what nature is for, specifically vis-à- 
vis policies around sustainability in Ottawa. Drawing on testimony of fifteen interview participants, participant observation in Old Ottawa South, and archival research, this thesis interrogates how policies around urban intensification and Smart Growth, though discursively framed as addressing the broader goals of urban sustainability, have largely been co-opted within a capitalist market system. Hegemonic discourses of sustainability currently operating in Ottawa uncritically privilege growth over other priorities and selectively value those aspects of (a commodified) nature that can contribute to this market system. Thus, particular discourses of sustainability in Ottawa have broader effects around urban development and neighbourhood change, as the re-framing of central neighbourhoods as sites of intensification (and thus commodification of these neighbourhoods as development opportunities) undermines aspects of community, identity, and heritage that local residents claim.

This thesis, therefore, identifies and interrogates the effects of co-opted and hegemonic discourses of sustainability operating in Ottawa. It also identifies counterhegemonic discourses and practices that residents mobilize to contest what they consider inappropriate development and to assert themselves as community members and activists, resisting effects of power that legitimate and render stable, hegemonic discourses of sustainability and growth. Finally, this thesis seeks to contribute to a future climate of possibility and hope, with a view to developing strategies within which individuals and collectives of individuals can negotiate and contest where necessary those policies and practices that conflict with the needs and desires of urban residents. 


\subsubsection{Theoretical contributions.}

In addition to critiquing urban political ecology, I hope to contribute to it (and disturb it in the process) by overlaying current research with questions of how knowledge is produced - particularly around nature - and how power and practice are implicated within the production and understanding of certain knowledges. By disturbing fixed ideas of what constitutes knowledge and how it comes to be accepted and normalized, I hope to add a reflexive layer to the body of research in urban political ecology - not for the purposes of discrediting or undermining it, but rather to challenge it to consider that knowledges do not have fixed starting points but are socially produced (often by scientific and other experts, but also by media, environmental groups, industry representatives, and others). Current urban political ecology research to a large extent focuses on the uneven exploitation of nature by an elitist and class-based capitalist society, without critically interrogating as a starting point the discursive production of nature that privileges particular knowledges - usually those that serve to further capitalist goals. I propose that poststructural insights - especially Foucaultian insights, but also those developed by scholars such as Castree (2001) and Gibson-Graham $(2003 ; 2006)$ who theorize both marxist and poststructural understandings - can only enrich what is currently largely a marxist body of research, disturbing concepts such as 'pristine first nature' and proposing in addition, a discursively produced social nature.

Conversely, this thesis aims to contribute to the growing literature on poststructural political ecology. Within this body of work, there is a noticeable gap in the research applied to the urban context: most poststructural political ecology research has 
thus far been conducted within rural or non-urban settings, particularly in the global south, and often in terms of exploitation of resources and uneven power relations (see Peet \& Watts, 1996; Simon, 2008; and Watts, 2000) for an assessment of political ecology since the 1980s). My goal for this thesis is to contribute to poststructural political ecology applied within an urban setting, using its important lines of inquiry and explanation to gain nuanced insights around knowledge, power, and discourse, specifically in the context of urban (re)development in central urban areas of the Canadian city.

\subsubsection{Theoretical next steps.}

This thesis merely skims the surface of the body of Foucault's work surrounding the operation of power, particularly within an institutional framework. Foucault's writing theorizes the operation of power at various scales across history (see Foucault, $1975 / 1977 \mathrm{a}$, for the disciplining power of institutions and disciplinary control of 'deviance'; see Foucault, 1973/1994a, for discussions of power and knowledge and his treatment of ideology; see Foucault, 1982/1994c, for discussions of the exercise of power, particularly vis-à-vis governments and other 'authorities'). Further inquiries into how power operates could contribute to important criticisms of municipal governance in Ontario. This will be discussed with specific reference to the OMB in Section 6.3.

\subsection{Sustainability, Community, and Heritage in Old Ottawa South}

As Chapter 4 shows, hegemonic discourses of sustainability currently operating in Ottawa and the rest of Ontario are legitimated, empowered and rendered stable by the 
institutional structures that normalize the terms of these discourses. I have shown through a brief and simplistic, but illustrative, genealogy of urban planning in Ontario that official plans in the RMOC and the City of Ottawa parallel the shifting discursive terrain of development, growth, and sustainability operating in the Ottawa region. Discourses of urban intensification in Ottawa rely on discourses of growth and are widespread within municipal and provincial governments and among many social actors in Old Ottawa South. Scalar influences also affect discourses of urban intensification: higher levels of governmental bodies, including the United Nations (UNCED, 1993), frame municipalities as the most appropriate sites for sustainability initiatives. However, as individuals in Old Ottawa South increasingly perceive infill development and redevelopment (legitimated by intensification policies) as inappropriate, these individuals contest the terms of these sustainability discourses. Social actors in Ottawa also mobilize discourses of nature for the purposes of either legitimating or contesting political, institutional, and economic practices that these actors either accept as normal and progressive, or reject as inappropriate and threatening.

As Chapter 5 shows, municipal policies in Ottawa largely frame community, sustainability, and heritage as discrete, seemingly uncontested, and transparently understandable categories that may or may not fall under the purview of municipal governments or the planning experts who advise government leaders. Municipal governance around urban development, particularly within official plans and zoning bylaws, privileges land-use planning and relies on planning models and experts to carry on as usual. In so doing, land-use planning documents often make claims of creating 
community and sustainability, while at the same time or within other planning documents and policies they enable economic (and physical) growth at the expense of all other priorities. Yet normative planning policies and the practices that they enable often serve to stifle debate, by normalizing, officializing, and rendering authoritative, knowledges that serve the needs and desires of politicians, planners, developers, and other special interests, but often not those of individuals living in communities affected by these policies.

Chapter 5 also shows that community identity is complex, requiring opportunities for public debate, as identities and subject positions are contingent and bound up continuously in processes of becoming. Community identity is made particularly visible when it is reformulated and brought to the fore within processes of activism and contestation. These processes also trigger counter arguments that undermine community identities by resubjectifying these identities as marginal, NIMBYist, privileged, or ignorant. As a result, subjects continually construct and reconstruct their own identities, and are also resubjectified by others, often for political or practical reasons.

\subsection{Practical Insights}

Rather than attempting to identify every practical challenge, limitation, or repercussion that I encountered during the course of this thesis, this section illustrates by way of select examples some challenges and tensions that emerged. This section also highlights some practical implications of the methods I chose, some preliminary insights into the process of transcription, and finally, two specific areas of research that I propose would be meaningful topics for further study. 


\subsubsection{Practical challenges: Methods.}

This thesis was conducted in a particular time frame with particular methods, always with the possibility of doing things differently. It is hindsight that affords one the opportunity to identify other questions, techniques, and procedures that might have proven more suitable, useful, or likely to generate 'better' results. Here I highlight briefly, by way of example, the practical choices that I made in terms of methods and timeframe, and some alternative possibilities that may have led to different results.

In general, I starting fieldwork later than what was initially planned and therefore I used a simplified research instrument that I felt would still fully address the research despite these time constraints. Practical reasons for the late start include a slightly longer ethics clearance process from what I had anticipated and the cancellation of a community meeting in March 2009, where I had hoped to introduce myself to the target research community. In fact, two OSCA meetings scheduled for the end of March 2009 - one to discuss CDPs and one to discuss parking - were cancelled. A third, the OSCA annual general meeting, was held in May; this is where I formally introduced my project to the community of Old Ottawa South. This four-week delay seemed to foreshadow the practical difficulties of organizing interviews and focus groups with busy people; although many ultimately agreed to interviews, the timeframe became longer and longer, with the last of the community interviews completed only in late November.

Although I would have liked more time for analysis and writing, the delays in the interview process provided additional and important time for transcription, reflection, and preliminary analysis. It also helped me become more comfortable with the interview 
process and to polish both my interview questions and my interview style. Furthermore, a longer interview period gave me time to re-examine the theoretical underpinnings of the project, allowing for more nuance within my lines of questioning. This was particularly important in the context of participant observation.

As a participant observer, life and research were very much intertwined. I often felt disconnected from the research project as I became more involved in the day-to-day operation of OSWatch and OSHP activities. Reflecting on the research process, especially by using a personal log, helped me to re-engage with the project, especially with respect to the various theoretical concepts informing my research. As such, processes of doing fieldwork and 'writing up' became conflated, which although this perhaps makes for more challenging time-management, can also be beneficial to the research project. Hoggart et al. (2002) cite a growing body of literature that sees writing up as integral to the processes of fieldwork and data collection. They see separation of fieldwork and writing up as linked to a modernist tradition (particularly in ethnography), where the writing up process is a form of authentication, polished for the purposes of 'fitting' in to theoretical objectives and 'cooked' into presentable and publishable material (p. 286). Against this harsh criticism, they propose that research and writing should not be so disjointed - that research should be done "in a self-reflective manner, in which our own positionalities, prejudices and comfortable associations are laid bare ... [since] any distanciation from the rawness (realness) of 'the research process' introduces false distinctions" (p. 287). One way to do this is to begin writing within the field, as research 
is being conducted. This serves to create a climate of self-reflexivity but it also helps to inform the research trajectory in an iterative fashion and provide initial insights that can be used and addressed when conducting research in the field.

In addition to using interviews as a method, I had planned to use focus groups and structured my research instrument to a large degree on that basis. Thus, I divided participants into categories based on their involvement with each contested development project, affiliation with OSCA, affiliation with OSHP, and local business owners. Based on these categories, I developed interview guides for interviews and focus groups, with the intent of conducting focus groups with the already-existing organizations and interviews with individuals involved in the contested development project.

The advantages of, and challenges to, focus groups are well documented. For example, they are often used to gain a large number of participant responses in a small amount of time and to stimulate dialogue between different actors (Cameron, 2005; Conradson, 2005; Longhurst, 2003). For Cameron (2005), an ideal size for a focus group is between six and ten people, and the greatest attribute of focus groups is a sense of energy flowing between participants, who use this energy to feed off each other. In addition to these aspects, I wanted to use focus groups because as opposed to interviews, they provide an opportunity to compare more directly participants' perceptions and understandings on issues, such as the effects of infill development on community identity, or the role of small businesses in a neighbourhood. A focus group can highlight areas where participants agree and disagree through debate and discussion, by 
highlighting particular (often subtle) ways that views differ or align with each other (Cameron, 2005; Conradson, 2005). Focus groups can also be used in combination with other methods in order to more fully understand particular areas of research; this process of triangulation is important to compare different sources and types of data to develop a greater understanding and to more fully address the research question (Longhurst, 2003).

For these reasons, I wanted to create focus groups composed of the abovementioned and already existing groups of people. However, it became clear early on that organizing this many people (6-10 per group) was unlikely to succeed, especially given my time frame and the hesitance of people to participate it yet another time-consuming meeting. I attempted to recruit participants by mailing or e-mailing letters of information to potential participants requesting them to participate in a focus group. Interestingly, all declined focus group participation but readily offered to give an interview. Within the context of power and control over the research process, there was little I could offer in order to facilitate focus group meetings. Most people were already involved in volunteer organizations and were generally unwilling to participate in focus groups. As such, after a couple of weeks of participant recruitment, I had organized several interviews but had to abandon focus groups as a method. I also re-focussed my energy on participant observation, particularly by become involved with OSWatch and OSHP.

\subsubsection{Transcription as a 'research moment'.}

As mentioned in Chapter 3, transcription of interview material was a process that remains for me an area of uncertainty. One interview participant in particular (see Chapter 3) triggered a reflexive re-evaluation of my motivations for how I was transcribing and what 
I hoped to achieve by doing so. I consider this a 'research moment' - a particularly insightful point in the research process that led to my increased reflexivity of the research process and a questioning of accepted techniques for interview transcription.

My first transcriptions were very detailed and included all vocalizations, pauses, and false starts (denoted by three dots or spelling out the 'umms' and 'ahhs') and also incorporated a variety of additional parenthetical observations of the interview process; this transcription process changed somewhat over the course of the research, as will be discussed below. Additionally, I used my interview guide to make additional comments about non-verbal activities or contextual information that I felt would not be captured within a digital audio recording. This fairly detailed transcription method was motivated by two factors. First, I wanted to capture the interview as 'accurately' as possible and thus felt compelled to include as much as possible. Second, the literature on interviewing and transcription widely and confidently extols the virtues of a 'robust', time-consuming, and complex system of transcription, motivated by reflexivity and claims to nuance that requires more than simple writing of words spoken but rather insists on hermeneutical systems of codes and symbols (see for example, Conradson, 2005, pp. 140-141; Dunn, 2005, pp. 96-99; Longhurst, 2003, pp. 125-126). Despite this literature and my own motivations, I struggled with these arguments and continue to question the insistence on using systems of symbols to capture nuance or make the process 'robust'; I am also troubled by my own transcriptions as purported 'records' of the interviews. I remain uncertain for two reasons. First, I am sceptical that any system of symbols can capture 
the atmosphere or 'intent' of interview participants any more than an absence of symbols. Any symbol requires translation; differences between a participant's style of speech and/or mannerisms tend to be homogenized via transcription symbols, and these symbols overemphasize things like false starts or mis-speech, leaving it to the researcher to construct meaning. Conradson (2005) gives the following examples of transcription symbols: square brackets to denote where two participants were talking at once; bracketed numbers to indicate length of pauses between speech; underlined text to emphasize speech; and capital letters to signal increased volume. But how does one judge the significance of these speech patterns? If someone starts talking louder what does this mean? Does it mean the same thing across participants? If someone is pausing for thought, does this mean they don't understand the issue, are hesitant to give a response, or perhaps simply want to take some time to give a well thought out response? Clearly, any set of symbols will not only fail to accurately capture meaning (unless it is extremely complex and tailored to each specific interview) but it will also produce meaning, only part of which may be accurate.

Second, during discourse analysis, most of my initial transcription symbols for false starts, and 'umms' and 'ahhs' were effectively left out of the thesis. They remain uninterpreted and un-used, not only because this type of analysis is somewhat beyond the scope of Foucaultian discourse analysis (although not other types of linguistic discourse analyses) but also because I was extremely uncomfortable in assigning meaning to nonverbal cues. Furthermore, as outlined in Chapter 3 and explained by Rose (2001), 
discourse analysis does not claim to reveal hidden meaning or require hermeneutics to find meaning. Discourse analysis examines what can be articulated through language and perceived through practice (Waitt, 2005) and how 'regularities' or 'discursive structures' can be found through careful analysis of statements (Foucault, 1969/1972). Foucault (1969/1972) also advises that the discourse analyst suspend all pre-existing assumptions and to read text with an open mind; this is indeed a challenge when reading and rereading familiar material, but it is essential to find those meanings that may not be immediately apparent and/or to allow the possibility of finding 'regularities' even if initial readings have excluded them.

The intent of this discussion is not to undermine the significance of non-verbal cues, speech patterns, or attempts to capture mood and context during interviews. Nor is it to simplify the transcription process in order to 'make it easier'. My rejection of transcription symbols likely made transcription and analysis more time consuming, due to my use of alternative techniques. Following Foucault (1969/1972), I relied on discourse analysis rather than transcription to find meaning from the interview material. As such, my interview material never really became quantitative data; neither was it made significant through the use of symbols and content-based systems of analysis. It became meaningful and useful through multiple re-readings and systematic cross-referencing of transcript texts, as well as through multiple listenings of the audio recordings and through engagement with my personal log and interview guide notes. I cannot claim that audio recordings are the record of informants: interviews were situated, I selected both participants and questions, and relationships of power were woven throughout the 
interview process. However, for the purposes of this thesis, I relied on the audio recordings, often using multiple listenings, to gain a better understanding of non-verbal cues, atmosphere, irony, sarcasm, and so on, and in fact used this in the thesis (as well as written comments of, for example, obvious physical gestures). On the other hand, giving text particular meaning based on my own translation of what non-verbal cues represent is not something that I ever became comfortable with during the course of this thesis.

\subsubsection{Practical limitations.}

Many topics emerged during this research project that I deem important but beyond the scope of this thesis, two of which include the current redevelopment of Lansdowne Park (which if approved will seriously impact Old Ottawa South) and the apparent excessive authority of the OMB in influencing urban development. The first example was a relatively simple matter to leave out of the thesis. The Lansdowne Park redevelopment proposal is ongoing and it is likely that many researchers from various theoretical fields will analyse this redevelopment. Furthermore, in developing a proposal, I already had identified several contested development projects that individuals deemed important enough to contest and which were directly related to discourses of sustainability and claims of community, identity, and heritage, particularly within the residential neighbourhood of Old Ottawa South. Thus, I was confident that my case study and methods were robust in their ability to address the research question. That said, the Lansdowne Park 'issue' occupied much of OSWatch's time and effort (and thus my own as well, as a participant observer) and in many ways inadvertently contributed to important insights for this thesis. 
The OMB, on the other hand, is a particularly powerful 'institution' in terms of urban development in Ontario - is it, in fact, unique to Ontario - and arose at almost every turn during the course of the research. Its operation and practical consequences are complex, widespread, and require critical study. Although research on the OMB is largely absent within the academic literature, it was simply too broad to do justice to in this thesis. Throughout this thesis, either implicitly or explicitly, I have identified ways that the OMB could be studied further. Several interview participants opined that the OMB has too much power, favours property developers, and is designed to be the battleground of 'experts', not ordinary citizens. One interview participant - an urban planning and heritage consultant and thus perhaps one of the experts - did not feel that planning in Ontario is only the domain of experts, as there are many tools that individuals can use to influence planning and are not all beyond the capacity of ordinary citizens. It would be very insightful, therefore, to analyse how power is exercised with respect to the Provincial Government of Ontario and particularly through the OMB, what justifications the OMB uses to enable particular development and halt others, and how relations of power influence scalar discourses of sustainability. Practically, it would also be useful to produce a record of OMB decisions, quantifying how the OMB has ruled in the past visà-vis property developers, municipal governing bodies, and individual citizens (see Chipman, 2002 for a critical evaluation of the OMB). Furthermore, Foucault's (1978/1994b) work on governmentality would be a useful avenue with which to study the power of the provincial government of Ontario and the OMB; particularly useful here would be a genealogical history that traces policies and practices that the provincial and 
municipal governments in Ontario use/used to enable its continued existence. Also useful for this type of analysis is the work of historical materialist or marxist geographers, who study power relations that enable governments and powerful elites to create conditions for the purposes of maintaining particular capitalist arrangements (e.g., provincial policies that dictate how municipalities regulate land use).

Particularly relevant to both Gramscian and Foucaultian notions of power is the "possibility of transformative politics" (Ekers \& Loftus, 2008, p. 711; see also Rankin, 2009 , for a discussion of critical approaches to planning theory to develop a "postcolonial ethics of planning that is accountable to marginalized groups" [p. 225]). For Gramsci, this is achieved through struggle and assertion of competing ideologies, often by forging alliances with groups with common interests (Ekers \& Loftus, 2008). For Foucault, power is everywhere and exercises of power are reversible; the imbalance of human relations that allow one to exercise power over another is ultimately always resisted (Bess, 1988; Foucault, 1982/1994c). Although many scholars illustrate the tensions between historical materialism (and its Gramscian notions of hegemony) and Foucaultian poststructuralism (e.g., Barnett, cited in Ekers \& Loftus, 2008), commonalties do exist $^{47}$, and in the spirit of weak theory, possibility, and hope, I imagine a scholarship that can draw on the works of others, reconciling tensions where possible while leaving the door open for debate around those differences some might consider irreconcilable.

\footnotetext{
${ }^{47}$ Although Foucault's 'governmentality' and Gramsci's 'hegemony' theorize state power differently (most notably Foucault theorizes power as originating in 'micro-practices' [Foucault, 1973/1994a], whereas Gramscian hegemony starts with a powerful ruling class, leaving the origins of this power under-theorized [Ekers \& Loftus, 2008]), both theories can inform useful trajectories of urban research, particularly in such fields as political ecology and critical urban theory.
} 


\subsection{Conclusion}

As I write this, OSWatch is attempting to develop a process that gives residents more say in how development occurs in Old Ottawa South. The City of Ottawa relies on planning tools that are consistent with and 'permitted' by provincially influenced official plans. CDPs, secondary plans, and zoning studies are three such mechanisms that the City can approve for neighbourhoods like Old Ottawa South. OSWatch, however, is doing its own assessment of what it deems will be most appropriate for Old Ottawa South, by consulting with its residents and trying to come up with a solution to the perceived problem of invasive and inappropriate development. I wish to highlight this type of action as necessary to disturb current operations of power and to influence processes of urban development. I hope that residents of Old Ottawa South and the broader community of urban residents can understand how knowledge, power, and practices are interwoven and how certain knowledges are privileged, especially those that are institutionalized or deemed 'expert' in some way.

Returning again to weak theory, I encourage residents of Old Ottawa South to open up, if they have not done so already, to the possibility that action and activism need not follow defined structures and procedures privileged by municipal government. Without completely abandoning the hierarchical nature of municipal government, which normalizes the structure of community associations, ward councillors, and the broader collective of city council, I challenge individuals to operate in other ways as well. One of my interview questions was, "What do you consider the most appropriate scale at which to act?" I was both surprised and encouraged by the diversity of responses. I expected 
most respondents to favour localized action but this was not the case. Answers differed greatly, perhaps based on individual experiences, perhaps based on participant understandings of governance structure in Ontario. No matter what the reason, it became clear to me that individuals are willing to engage in different ways across different scales. Appealing directly to the provincial or even federal government, meeting with a variety of school board trustees (not just those within the local ward), developing personal relationships with individuals from other communities, appealing to other ward councillors: these are but a few of the many ways that individuals can apply weak theory. They can accept that there many possible ways of doing things: that if one goes beyond the standard procedures by which the City operates (e.g., community associations voicing their concerns - often through disembodied e-mails - to the ward councillor who can then decide whether or not to bring issues to council), that action will not be in vain. Similarly, I encourage individuals to evaluate critically the knowledge of experts, such as developers and planners, and to recognize that this knowledge is an effect of power. Expert knowledges, like all knowledges are discursively produced and should always remain open to question and contestation in a free and democratic society. 


\section{Literature Cited}

Bess, M. (1988). Interview with Michel Foucault: Power, moral values, and the intellectual, September 3, 1980. History of the Present, 4, 1-2, 11-13.

Blaikie, P., \& Brookfield, H. (1987). Land degradation and society. London: Methuen.

Braun, B., \& Wainwright, J. (2001). Nature, poststructuralism, and politics. In N. Castree \& B. Braun (Eds.), Social nature: Theory, practice, and politics (pp. 41-65). Oxford: Blackwell.

Brenner, N. (2001). The limits to scale? Methodological reflections on scalar structuration. Progress in Human Geography, 25(4), 591-614.

Brenner, N., Marcuse, P., \& Mayer, M. (2009). Cities for people, not for profit. City, 13(2), 176-184.

Brisset, A. (2008). Hitting a wall: How densified do we want our neighbourhood to become? The Oscar, 35(2), 8 .

Bruegmann, R. (2005). Sprawl: A compact history. Chicago: University of Chicago Press.

Brunet-Jailly, E. (2008). Vancouver: The sustainable city. Journal of Urban Affairs, 30(4), 375-388.

Bunce, S. (2004). The emergence of 'Smart Growth' intensification in Toronto:

Environment and economy in the new official plan. Local Environment, 9(2), 177-191.

Burawoy, M. (1998). The extended case method. Sociological Theory, 16(1), 4-33.

Butler, J. (1990). Gender trouble. New York: Routledge.

Butler, J. (1992). Contingent foundations: Feminism and the question of 'postmodernism'. In J. Butler \& J. Scott (Eds.), Feminists theorize the political (pp. 3-21). New York: Routledge.

Cairns, H. (2008). This is my business. The Oscar, 36(11), 12.

Calgary, City of. (2007). Integrated land use and mobility plan: Details of sustainability principles for sustainability and mobility. Calgary: Plan It Calgary.

Calthorpe, P. (1993). The next American metropolis. Princeton: Princeton Architectural Press.

Cameron, J. (2005). Focussing on the focus group. In I. Hay (Ed.), Qualitative research methods in human geography ( $2^{\text {nd }}$ ed.) (pp. 156-174). Melbourne: Oxford University Press. 
Campanale Homes. (2008). 37 Brighton. Retrieved from http://www.campanale.com/Campanale_site/communities_6grove.aspx (accessed April, 2010).

Campanale Homes. (2009). 37 Brighton [Brochure]. Campanale Homes: Author.

Campsie, P. (1995). The social consequences of planning talk: A case study in urban intensification. Toronto: University of Toronto Centre for Urban and Community Studies.

Campsie, P. (2001). Smart Growth in Canada. Toronto: The Canadian Urban Institute.

Carma Developers LP. (2009). Come together: McKenzie Towne - A small towne in the city. Retrieved from http://www.mckenzietowne-community.com/ (accessed June, 2010).

Castree, N. (2001). Marxism, capitalism, and the production of nature. In N. Castree \& B. Braun (Eds.), Social nature: Theory, practice, and politics (pp. 189-207). Oxford: Blackwell.

Chipman, J. (2002). A law unto itself: How the Ontario Municipal Board has developed and applied land use planning policy. Toronto: University of Toronto Press.

Colombo, M., \& Senatore, A. (2005). The discursive construction of community identity. Journal of Community and Applied Social Psychology, 15, 48-62.

Congress for the New Urbanism (CNU). (2001). Charter of the new urbanism. Chicago: CNU.

Conradson, D. (2005). Focus groups. In R. Flowerdew \& D. Martin (Eds.), Methods in human geography: A guide for students doing a research project $\left(2^{\text {nd }}\right.$ ed.) (pp. 128143). Harlow, UK: Pearson Education Ltd.

Cook, I. (2005). Participant observation. In R. Flowerdew \& D. Martin (Eds.), Methods in human geography: A guide for students doing a research project $\left(2^{\text {nd }} \mathrm{ed}\right.$.) (pp. 167190). Harlow, UK: Pearson Education Ltd.

Cook, M. (2008, June 23). Intensification versus 'uglification'. The Ottawa Citizen, Retrieved from http://www.canada.com/ottawacitizen/news/city/story.html?id=57f7a703-2a12-4de095e9-d452b6f15100 (accessed February, 2010).

Cook, M. (2008, October 27). Small victory in Old Ottawa South. The Ottawa Citizen, Retrieved from http://www.canada.com/ottawacitizen/news/city/story.html?id=fd58bceb-e2c2-485187dc-a5fd89b8ab46\&k=14005\&p=1 (accessed February, 2010). 
Cook, M. (2009, September 23). Big infill: Why Brighton St. allowed but QED will be 'test case'. The Ottawa Citizen, Retrieved from $\mathrm{http}: / /$ communities.canada.com/OTTAWACITIZEN/blogs/designingottawa/archive/2 009/09/23/big-infill-why-brighton-st-was-allowed-but-qed-will-be-quot-test-casequot.aspx (accessed February, 2010).

Cox, W. Consultancy. (2000). Calgary's McKenzie Towne: Suburb with a neo-traditional facade. Bellville, Illinois: Wendell Cox Consultancy. Retrieved from http://www.demographia.com/db-mckenzietowne.htm (accessed June, 2010).

Creese, W. (1966). The search for environment: The garden city, before and after. New Haven: Yale University Press.

Cullen, A. (2010, March). Politics and the governance of sprawl. Environmental Studies 3000 Colloquium. Lecture conducted from Carleton University, Ottawa, ON.

Cummer, D. (2002). Public meeting to discuss future of school building. The Oscar, 30(6), 5.

Currie, J. (2004). Searching for common ground on 88 Bellwood. The Oscar, 30(8), 1.

Dalby, S., \& Mackenzie, F. (1997). Reconceptualising local community: Environment, identity and threat. Area, 29(2), 99-108.

Dean, J. (2005). 'Said tree is a veritable nuisance': Ottawa's street trees 1869-1939. Urban History Review, 34(1), 46-57.

Doucet, C. (2007). City Councillor's report: Trees, greenspace and intensification. The Oscar, 33(5), 7.

Doucet, C. (2008a). City Councillor's report: Street meter parking and Charlesfort proposal. The Oscar, 35(2), 7.

Doucet, C. (2008b). City Councillor's report: Shoppers Drugmart and Mayfair Theatre. The Oscar, 36(10), 7.

Dowler, L. (2001). Fieldwork in the trenches: Participant observation in a conflict area. In M. Limb \& C. Dwyer (Eds.), Qualitative methodologies for geographers (pp. 153164). London: Arnold.

Duany, A., Plater-Zyberk, E., \& Speck, J. (2000). Suburban nation: The rise of sprawl and the decline of the American Dream. New York: North Point Press.

Dunn, K. (2005). Interviewing. In I. Hay (Ed.), Qualitative research methods in human geography ( $2^{\text {nd }}$ ed.) (pp. 79-105). Victoria: Oxford University Press. 
Ekers, M., \& Loftus, A. (2008). The power of water: Developing dialogues between Foucault and Gramsci. Environment and Planning D: Society and Space, 26, 698-718.

EMC. (2009, December 24). City of Ottawa population reaches 900,000. Ottawa West $E M C$. Retrieved from

http://www.emcottawawest.ca/20091224/news/City + of + Ottawa + population + reaches + 900,000 (accessed April, 2010)

England, K. (2006). Producing feminist geographies: Theory, methodologies and research. In S. Aiken \& G. Valentine (Eds.) Approaches to human geography (pp. 286-297), London: Sage.

Escobar, A. (1996). Constructing nature: Elements for a poststructural political ecology. In R. Peet \& M. Watts (Eds.), Liberation ecologies: Environment, development, social movements (pp. 46-68). London: Routledge.

External Advisory Committee on Cities and Communities (EACCC). (2006), From restless communities to resilient places: Building a stronger future for all Canadians. Ottawa: External Advisory Committee on Cities and Communities.

Fagan, L. (2010, May 21). Big, modern home plans up in the air. CBC News. Retrieved from http://www.cbc.ca/canada/ottawa/story/2010/05/19/ottawa-west-wellingtonhome.html\#socialcomments (accessed June, 2010).

Filion, P. (2003). Towards Smart Growth? The difficult implementation of alternatives to urban dispersion. Canadian Journal of Urban Research, 12(1), 48-70.

Filion, P., McSpurreno, K., \& Appleby, B. (2006). Wasted density? The impact of Toronto's residential-density-distribution policies on public-transit use and walking, Environment and Planning, 38: 1367-1392.

Finlay, B. (2010). The planning and growth management department: Where do we fit in? Planning Primer session I, April 10, 2010. Ottawa: City of Ottawa Planning and Growth Management Department.

Foucault, M. (1972). The archeology of knowledge. (A.M. Sheridan Smith, Trans.). New York: Pantheon Books. (Original work published 1969).

Foucault, M. (1977a). Discipline and punish: The birth of the prison. (A. Sheridan, Trans). New York: Random House. (Original work published 1975).

Foucault, M. (1977b). Nietzsche, genealogy, history. In D. Bouchard (Ed.), Language, counter-memory, practice: Selected essays and interviews (pp. 139-164) (D. Bouchard \& S. Simon, Trans.). Ithaca: Cornell University Press. (Original work published 1971). 
Foucault, M. (1983, April 12). The culture of the self: Introduction, program part II and discussion (audio file). Retrieved from Berkeley Language Center, Speech Archive SA 1456: http://sunsite.berkeley.edu/VideoTest/foucault-cult2.ram (accessed September, 2010).

Foucault, M. (1994a). Truth and juridical forms. In J.D. Faubion (Ed.), Power (pp. 1-89) (R. Hurley et al., Trans.). New York: The New Press. (Original work published 1973).

Foucault, M. (1994b). Governmentality. In. J.D. Faubion (Ed.), Power (pp. 201-222) (R. Hurley et al., Trans.). New York: The New Press. (Original work published 1978).

Foucault, M. (1994c). The subject and power. In J.D. Faubion (Ed.), Power (pp. 326-348) (R. Hurley et al., Trans.). New York: The New Press. (Original work published 1982).

Fraser, M. (2004). Residents unite to protect zoning at 88 Bellwood, The Oscar, 30(9), 12.

Fraser, M. (2005). Residents continue fight to protect zoning at 88 Bellwood, The Oscar, $31(1), 16$.

Frey, P. (2008) Building reuse: Finding a place on American climate policy agendas. Washington, DC: National Trust for Historic Preservation.

Fullerton, C. (2005). A changing of the guard: Regional planning in Ottawa, 1945-1974. Urban History Review, 34(1), 100-112.

Gahin, R., \& Paterson, C. (2001). Community indicators: Past, present, and future. National Civic Review, 90(4), 347-361.

Gandy, S. (2006). Urban nature and the ecological imaginary. In N. Heynen, M. Kaika \& E. Swyngedouw (Eds.), In the nature of cities: Urban political ecology and the politics of urban metabolism (pp. 63-74). London: Routledge.

Gibson-Graham, J.K. (2003). An ethics of the local. Rethinking Marxism, 15(1), 49-74.

Gibson-Graham, J.K. (2006). A postcapitalist politics. Minneapolis: University of Minnesota Press.

Grammenos, F. (2007). The smart growth gap. Plan Canada, 47(2), 41-44.

Grant, J. (2006a). Planning the good community: New Urbanism in theory and practice. New York: Routledge.

Grant, J. (2006b). The ironies of new urbanism. Canadian Journal of Urban Research, $15(2), 158-174$. 
Grant, N. (2009). Shoppers Drug Mart at Bank and Sunnyside: Risk and safety issues. The Oscar 37(2), 20-21.

Gréber, J. (1950). Plan for the National Capital. Ottawa: National Capital Planning Service.

Gunder, M. (2006). Sustainability: Planning's saving grace or road to perdition? Journal of Planning Education and Research, 26, 208-221.

Hanna, R. (1982, August 23). Nine schools on chopping block this year. The Ottawa Citizen, p. 54.

Harding, S. (1987). Introduction: Is there a feminist method? In S. Harding (Ed.), Feminism and methodology (pp. 1-14). Bloomington, IN: Indian University Press.

Harper, K. (2008). The realities of the Shoppers Drug Mart proposal. The Oscar, 36(11), 11.

Hart, G. (2004). Geography and development: Critical ethnographies. Progress in Human Geography, 28(1), 91-100.

Hart, G. (2006). Denaturalizing dispossession: Critical ethnography in the age of resurgent imperialism. Antipode, 38(5), 977-1004.

Harvey, D. (2003). The right to the city. In R. Scholar (Ed.), Divided cities (pp. 83-103). Oxford: Oxford University Press.

Hecht, P. (2010). Tsunami of change. The Oscar, 37(6), 27-29.

Heynan, N., Kaika, M., \& Swyngedouw, E. (2006). Urban political ecology: Politicizing the production of urban natures. In N. Heynen, M. Kaika \& E. Swyngedouw (Eds.), In the nature of cities: Urban political ecology and the politics of urban metabolism (pp. 1-20). London: Routledge.

Hemson Consulting Ltd. (2009). Comparative municipal fiscal impact analysis. Ottawa: Hemson Consulting Ltd.

Hoggart, K., Lees, L., \& Davies, A. (2002). Researching human geography. London: Arnold.

Hua, J. (2010, June 29). Ottawa council votes in favour of Lansdowne redevelopment. CTV News. Retrieved from http://ottawa.ctv.ca/servlet/an/local/CTVNews/20100629/OTT_LANSDOWNE_VOT E_100629/20100629?hub=OttawaHome (accessed July 23, 2010).

Hunter, J. (2008). Shoppers Drug Mart developer meeting. The Oscar, 36(10), 8. 
Jackson, K. (1985). Crabgrass frontier: The suburbanization of the United States. New York: Oxford University Press.

Jackson, P. (2000). Ethnography. In R.J. Johnston, D. Gregory, G. Pratt, \& M. Watts (Eds.), Dictionary of human geography ( $4^{\text {th }}$ ed.) (pp. 238-239). Oxford: Blackwell.

Jacobs, J. (1961). The death and life of great American cities. New York: Random House.

Jenkin, M. (2004). OSCA president's report: Community divided over 88 Bellwood. The Oscar 30(8), 5.

Jenkin, M. (2005). OSCA president's report: 88 Bellwood re-zoning application to be heard. The Oscar 31(2), 5.

Jenkin, M., \& McCoy, B. (2009). Ottawa South Community Association presentation to Ottawa City Council on Lansdowne Live Proposal, November 12, 2009. Ottawa.

Jensen, D. (1982, October 23). Parents put up fight against school closing. The Ottawa Citizen, pp. 41.

Kaika, M. (2006). Dams as symbols of modernization: The urbanization of nature. Annals of the Association of American Geographers, 96(2), 276-301.

Katz, P. (1994). The new urbanism: Toward an architecture of community. New York: Random House.

Kealey, P. (2004). Developer shouldn't get St. Margaret Mary's. The Oscar, 30(7), 3.

Kealey, P. (2005). Ottawa committee votes to rezone 88 Bellwood. The Oscar, 31(3), 1.

Keil, R. (2003). Urban political ecology. Urban Geography, 24(8), 723-738.

Keil, R., \& Boudreau, J. (2006). Metropolitics and metabolics: Rolling out environmentalism in Toronto. In N. Heynen, M. Kaika \& E. Swyngedouw (Eds.), In the nature of cities: Urban political ecology and the politics of urban metabolism (pp. 41-62). London: Routledge.

Kenworthy, J. (2006). The eco-city: Ten key transport and planning dimensions for sustainable city development. Environment and Urbanization, 18(1), 67-85.

Krueger, R., \& Gibbs, D. (2008). 'Third wave' sustainability? Smart growth and regional development in the USA. Regional Studies, 42(9), 1263-1274. 
Kunstler, J. (1993). The geography of nowhere: The rise and decline of America's manmade landscape. New York: Simon \& Schuster.

Lefebvre, H. (1991). The production of space. (D. Nicholson-Smith, Trans.). Oxford: Blackwell. (Original work published 1974).

Liepins, R. (2000). Exploring rurality through 'community': Discourses, practices and spaces shaping Australian and New Zealand rural 'communities'. Journal of Rural Studies, 16, 325-341.

Longhurst, R. (2003). Semi-structured interviews and focus groups. In N. Clifford \& G. Valentine (Eds.), Key methods in geography (pp. 117-132). London: Sage.

Mackenzie, F. (2001). On the edge: 'Community' and 'sustainability' on the Isle of Harris, Outer Hebrides. Scottish Geographical Journal, 117(3), 219-240.

Mackenzie, F., MacAskill, J., Munro, G., \& Seki, E. (2004). Contesting land, creating community, in the Highland and Islands, Scotland. Scottish Geographical Journal, 120(3), 159-180.

Maclaren, V. (1996). Urban sustainability reporting. Journal of the American Planning Association, 62(2), 184-202.

Marcuse, P. (2000). The new urbanism: The dangers so far. DISP, 140:4-6. Retrieved from http://www.nsl.ethz.ch/index.php/en/content/download/320/1971/file (accessed June $14,2010)$.

Marsden, S. (2000). The social construction of scale. Progress in Human Geography, 24(2), 219-242.

Marshall, A. (2000). A more benevolent sprawl [Review of the book. Suburban nation: The rise of sprawl and the decline of the American dream, by A. Duany, E. PlaterZyberk, \& J. Speck]. Metropolismag.com, August. Retrieved from http://www.alexmarshall.org/am_articleFolder/a_more_benevolent_sprawl.htm (accessed July 13, 2010).

Maxwell, J. (2003). Sustainable cities. Plan, 43(3), 13-15.

McClymont, K., \& O'Hare, P. (2008). 'We're not NIMBYs!' Contrasting local protest groups with idealised conceptions of sustainable communities. Local Environment, 13(4), 321-335.

McCoy, B. (2010). OSWATCH. The Oscar, 37(5), 5. 
Mendes, W. (2007). Negotiating a place for 'sustainability' policies in municipal planning and governance: The role of scalar discourses and practices. Space and Polity, 11(1), 95-119.

Ministry of Municipal Affairs and Housing (MMAH). (1996). Provincial policy statement, 1996. Toronto: Queen's Printer.

Ministry of Municipal Affairs and Housing (MMAH). (2003). Municipal act e-guide. Toronto: Queen's Printer.

Ministry of Municipal Affairs and Housing (MMAH). (2005). Provincial policy statement, 2005. Toronto: Queen's Printer.

Ministry of Municipal Affairs and Housing (MMAH). (2009). Planning Act approval authority in Ontario. Toronto: Queen's Printer.

Minton, E. (1972, August 5). Ottawa South: After 50 years, mellowed but unbowed. The Ottawa Journal. Retrieved from http://ottawasouthhistoryproject.googlegroups.com/web/Minton-After+50+yearsOttawa + Journal $+1972+$ article +1 of $4 . p d f$.

Mitchell, D. (2003). The right to the city: Social justice and the fight for public space. New York: Guildford Press.

Montreal, City of. (2005). Montreal's sustainable development plan:

DeveloppementDurable. Montreal: City of Montreal.

Municipal Property Assessment Corporation (MPAC). (2008). AboutMyProperty. Toronto: MPAC. Retrieved from https://portal.mpac.ca/wps/portal/ (accessed Dec., 2008).

Ontario, Province of. (1989). Planning Act 1983, statutes of Ontario. Toronto: Ontario: Queen's Printer.

Oscar, The. (2005). The Moorcroft. The Oscar, 31(10), 29.

Ostling, K. (2008a). Development at 35 Brighton Avenue. The Oscar, 36(7), 8. Retrieved from http://www.oldottawasouth.ca/documents/oscar/2008/2008-07-July.pdf

Ostling, K. (2008b). Update on 35 Brighton Avenue. The Oscar, 36(10), 17. Retrieved from http://www.oldottawasouth.ca/documents/oscar/2009/2009-11-November.pdf

Ottawa, City of. (1978). Capital ward neighbourhood study: Existing conditions report, Ottawa South. Ottawa: City of Ottawa Department of Community Development. 
Ottawa, City of. (1991a). City of Ottawa official plan. (Vol. I): The primary plan. Ottawa: City of Ottawa.

Ottawa, City of. (1991b). City of Ottawa official plan. (Vol. II): Secondary policy plans / site specific policies. Ottawa: City of Ottawa.

Ottawa, City of. (2002). 88 Bellwood: Report to health, recreation and social services committee and council 10 July 2002. Ottawa: City of Ottawa Communications and Marketing. Retrieved from http:/www.ottawa.ca/calendar/ottawa/citycouncil/occ/2002/07-24/hrss/ACS2002CCS-HRS-0011.htm (accessed February, 2010).

Ottawa, City of. (2003a). A window on Ottawa 20/20: Ottawa's growth management strategy. Ottawa: City of Ottawa.

Ottawa, City of. (2003b). Urban design and zoning study: Old Ottawa South. Ottawa: City of Ottawa Planning and Development Committee.

Ottawa, City of. (2005a). Ottawa ward boundary review recommendations report. City of Ottawa: Corporate Services and Economic Development Committee. Retrieved from http://www.ottawa.ca/city_hall/ward/reports/recommendations/full_report_en.html (accessed April, 2009)

Ottawa, City of. (2005b). Urban design guidelines for low-medium density infill housing. Ottawa: City of Ottawa Planning and Growth Management Department.

Ottawa, City of. (2005c). Zoning - 88 Bellwood: Report to planning and environment committee and council 4 January 2005. Ottawa: City of Ottawa Communications and Marketing. Retrieved from http://www.ottawa.ca/calendar/ottawa/citycouncil/occ/2005/02-23/pec/ACS2005DEV-APR-0024.htm\#_msocom_6 (accessed April, 2009).

Ottawa, City of. (2006a). Urban design guidelines for development along traditional mainstreets. Ottawa: City of Ottawa Planning and Growth Management Department.

Ottawa, City of. (2006b). New ward structure and ward maps. Retrieved from http:/www.ottawa.ca/city_hall/ward/new_structure/index_en.html (accessed April, 2010).

Ottawa, City of. (2006c). 2005 land use survey. Ottawa: City of Ottawa Planning and Growth Management Department.

Ottawa, City of. (2007a). Brownfield redevelopment community improvement plan. Ottawa: City of Ottawa. Retrieved from http://www.ottawa.ca/residents/planning/brownfields/images/cip_2007_en.pdf 
Ottawa, City of. (2007b). City of Ottawa official plan: Consolidation (Vol. 1). Ottawa: City of Ottawa.

Ottawa, City of. (2007c). City housing strategy: 2007-2012. Ottawa: City of Ottawa Planning and Growth Management Department.

Ottawa, City of. (2007d). Getting greener: On the path of sustainability. Ottawa: City of Ottawa.

Ottawa, City of. (2007e). Transit-oriented development guidelines. Ottawa: City of Ottawa Planning, Transit, and Environment Department.

Ottawa, City of. (2008a). Residential intensification: Building more vibrant communities [White paper]. Ottawa: City of Ottawa Planning, Transit and Environment Department.

Ottawa, City of. (2008b). Development application no. D02-02-08-0081. Ottawa: City of Ottawa Development Services Department, Planning and Development Committee.

Ottawa, City of. (2008c). Zoning by-law 2008-250 consolidation. Ottawa: City of Ottawa. Retrieved from http:/www.ottawa.ca/residents/bylaw/a_z/zoning/parts/index_en.html (accessed June, 2010).

Ottawa, City of. (2009a). Beyond Ottawa 20/20: City Council approves official plan amendment. Ottawa: City of Ottawa Infrastructure Service and Community Sustainability. Retrieved from http://www.ottawa.ca/residents/planning/op/beyond_2020/index_en.html (accessed April, 2010).

Ottawa, City of. (2009b). Zoning - 1080 Bank Street (file no. D02-02-08-0081). Ottawa: City of Ottawa Planning and Environmental Committee. Retrieved from http://www.ottawa.ca/calendar/ottawa/citycouncil/occ/2009/01-28/pec/ACS2009-ICSPLA-0010.htm (accessed March, 2010).

Ottawa, City of. (2010a). [Base map of the City of Ottawa, 1:354,483]. Map layer data from eMap using Autodesk MapGuide $\mathbb{B}$ Viewer. Retrieved from http://apps104.ottawa.ca/emap/ (accessed July, 2010).

Ottawa, City of. (2010b). Projects. Retrieved from http://ottawa.ca/residents/construction/projects/index_en.html (accessed May, 2010).

Ottawa Evening Citizen, The. (1929, November 12). Roman Catholic parish created south of canal. The Ottawa Evening Citizen, pp. 27.

Ottawa Evening Citizen, The. (1930, September 23). To award contract for new separate school. The Ottawa Evening Citizen, pp. 16. 
Ottawa Evening Citizen, The. (1930, December 4). Will expropriate site for school: Move by S.S. board in Ottawa South. Also plans Cumberland St. purchase. The Ottawa Evening Citizen, pp. 24.

OttawaLiving.ca. (2009). Old Ottawa South: Ottawa neighbourhoods. Retrieved from http://www.ottawaliving.ca/community.php?community_id=28 (accessed June, 2010).

Ottawa Real Estate Board (OREB). (2009). Retrieved from http://orebweb1.oreb.ca/mlssearch/frm_SearchMlsDetails.asp?x_mls_num=718169 (accessed April, 2009).

Ottawa South Community Association (OSCA). (2006). A new old firehall for Old Ottawa South. Ottawa: Ottawa South Community Association, Retrieved from http://www.oldottawasouth.ca/static/miscellaneous/2006/info_pkg_1.pdf.

Ottawa South Community Association (OSCA). Old Ottawa South Community Association board minutes 2008-06-17. Ottawa: Ottawa South Community Association, Retrieved from http://www.oldottawasouth.ca/index.php/osca/docarchive/12/378-board

Parkinson, S., \& Roseland, M. (2002). Leaders of the pack: An analysis of the Canadian 'Sustainable Communities' 2000 municipal competition. Local Environment, 7(4), 411-429.

Paulson, S., Gezon, L., \& Watts, M. (2003). Locating the political in political ecology: An introduction. Human Organization, 62(3), 205-217.

Peace, R., \& van Hoven, B. (2000). Computers, qualitative data, and geographical research. In. I. Hay (Ed.), Qualitative research methods in human geography (2 $2^{\text {nd }}$ ed.) (pp. 234247). Victoria: Oxford University Press.

Pearson, M. (2010). Overbrook easements spur fiery debate: Angry residents cite loss of property, crime fears. The Ottawa Citizen, April 13. Retrieved from $\mathrm{http}: / /$ www.ottawacitizen.com/Overbrook+easements+spur+fiery+debate/2876016/sto ry.html (accessed April, 2010).

Peet, R., \& Watts, M. (1996). Liberation ecology: Development, sustainability, and environment in an age of market triumphalism. In R. Peet \& M. Watts (Eds.), Liberation ecologies: Environment, development, social movements (pp. 1-45). London: Routledge.

Penfold, G. (1998). Planning act: Reforms and initiative in Ontario. In J. Schnurr \& S. Holtz (Eds.). The cornerstone of development: Integrating environmental, social, and economic policies (pp. 149-176). Ottawa: International Development Research Centre. 
Pinchin Environmental. (2007). Phase II environmental site assessment, 1080 Bank Street and 297-305 Sunnyside Avenue, Ottawa, Ontario. Ottawa: Pinchin Environmental.

Pratt, G. (2004). Feminist geographies: Spatialising feminist politics. In P. Cloke, P. Crang, \& M. Goodwin (Eds.), Envisioning human geographies (pp. 128-145). London: Arnold.

Raco, M. (2007). Securing sustainable communities: Citizenship, safety and sustainability in the new urban planning. European Urban and Regional Studies, 14(4), 305-320.

Rees, A. (2003). New urbanism: Visionary landscapes in the twenty-first century. In M. Lindstrom \& H. Bartling (Eds.), Suburban sprawl: Culture, theory and politics (pp. 93-114). Lanham, Maryland: Rowman and Littlefield.

Reese, L. (2004). Same governance, different day: Does metropolitan reorganization make a difference? Review of Policy Research, 21(4), 595-611.

Regional Municipality of Ottawa-Carleton (RMOC). (1983). Official plan, OttawaCarleton planning area: A consolidation of the official plan of the Regional Municipality of Ottawa Carleton as approved by the Minister of Municipal Affairs and Housing and the Ontario Municipal Board of Cabinet. Ottawa: RMOC.

Regional Municipality of Ottawa-Carleton (RMOC). (1988). Official plan of the Regional Municipality of Ottawa-Carleton (Vol. 1). Ottawa : RMOC.

Renne, J. (2009). From transit-adjacent to transit-oriented development. Local Environment, 14(1), 1-15.

Robinson, P. (2009). Urban sustainability in Canada: The global-local connection. In C. Gore \& P. Stott (Eds.), Environmental challenges and opportunities: Local-global perspectives on Canadian issues (pp. 159-181). Toronto: EMP.

Rose, G. (1997). Situating knowledges: Positionality, reflexivities and other tactics. Progress in Human Geography, 21(3), 305-320.

Rose, G. (2001). Visual methodologies. London: Sage.

Roseland, M. (1992). Towards sustainable communities: A resource book for municipal and local governments. Ottawa: NRTEE.

Rosenfield, R., \& Reese, L. (2003). The anatomy of an amalgamation: The case of Ottawa. State \& Local Government Review, 35(1), 57-69.

Ruddy, C. (2010). Zoning. Planning primer session I, April 10, 2010. Ottawa: City of Ottawa Planning and Growth Management Department. 
Rupert, J. (2008, October 8). City, neighbourhood at odds over apartment: Intensification on trial in fight over tower on Industrial. The Ottawa Citizen. Retrieved from http://www.peterhume.ca/OttCit-340Industrial.pdf.

Rypkema, D. (1994). The economics of historic preservation: A community leader's guide. Washington D.C.: National Trust for Historic Preservation.

Sancton, A. (2005) The governance of metropolitan areas in Canada. Public Administration and Development, 25(4), 317-327.

Schecter, D. (2005). Beyond hegemony: Towards a new philosophy of legitimacy. Manchester: Manchester University Press.

Simon, D. (2008). Political ecology and development: Intersections, explorations and challenges arising from the work of Piers Blaikie. Geoforum, 39, 698-707.

Smart Growth Canada Network (SGCN). (2007). 10 principles of smart growth. Retrieved from http://www.smartgrowth.ca/home_e.html (accessed April, 2010).

Statistics Canada. (2007). Census tract (CT) profiles, 2006 census. Ottawa. Retrieved from http://www12.statcan.gc.ca/census-recensement/2006/dp-pd/prof/92597/index.cfm?lang=E (accessed April, 2010).

Swyngedouw, E. (1997). Neither global nor local: 'Glocalization' and the politics of scale. In K. Cox (Ed.), Spaces of globalization: Reasserting the power of the local (pp. $137-$ 166). New York: Guilford Press.

Talen, E. (1999). Sense of community and neighbourhood form: The social doctrine of new urbanism. Urban Studies, 36(8), 1361-1379.

Tansey, B. (2008). What's wrong with the Shopper's application? The Oscar, 36(11), 10.

Taylor, J. (1986). Ottawa: An illustrated history. Toronto: James Lorimer \& Co.

Tomalty, R., \& Alexander, D. (2005). Smart growth in Canada: Implementation of a planning concept. Ottawa: Canadian Mortgage and Housing Corporation.

Tonkiss, F. (1998). Analysing text and speech: Content and discourse analysis. In C. Seale (Ed.), Researching society and culture ( $2^{\text {nd }}$ ed.) (pp. 367-382). London: Sage.

Toronto, City of. (2007). Toronto official plan. Toronto: City of Toronto.

Tregoning, H., Agyeman, J., \& Shenot, C. (2002). Sprawl, smart growth, and sustainability. The International Journal of Justice and Sustainability, 7(4), 341-347. 
Turvey, J., \& Konyi, B. (2009). Farmland protection and sustainable urban communities in Ontario. Plan, 49(2), 24-30.

Tweed, C., \& Sutherland, M. (2007). Built cultural heritage and sustainable urban development. Landscape and Urban Planning, 83, 62-69.

United Nations Conference on Environment and Development (UNCED). (1993). Agenda 21, programme of action for sustainable development: Rio declaration on environment and development. New York: United Nations Department of Public Information.

United Nations Environment Programme (UNEP). (1972). Declaration of the United Nations conference on the human environment. .Nairobi: UNEP.

United Nations Environmental Programme (UNEP). (2002). Melbourne principles for sustainable cities. Osaka: UNEP.

UN-Habitat. (2008). Urban growth patterns. In R. Waraj (Ed.), State of the world's cities 2008/2009: Harmonious cities (pp. 10-23). London: Earthscan.

Valentine, G. (2005). Tell me about ...: Using interviews as a research methodology. In R. Flowerdew \& D. Martin (Eds.), Methods in human geography: A guide for students doing a research project ( $2^{\text {nd }}$ ed.) (pp. 110-127). Harlow, UK: Pearson Education Ltd.

Vancouver, City of. (2008). EcoDensity: Vancouver EcoDensity charter. Vancouver: City of Vancouver.

Van Velsen, J. (1967). The extended-case method and situational analysis. In A. Epstein (Ed.), The craft of social anthropology (129-149). London: Tavistock.

Waitt, G. (2005). Doing discourse analysis. In I. Hay (Ed.), Qualitative research methods in human geography (2 ${ }^{\text {nd }}$ ed.) (pp. 163-191). Victoria: Oxford University Press.

Watts, M. (2000). Political ecology. In R.J. Johnston, D. Gregory, G. Pratt, \& M. Watts (Eds.), Dictionary of human geography $\left(4^{\text {th }}\right.$ ed.) (pp. 590-593). Oxford: Blackwell.

Webster's Encyclopedic Unabridged Dictionary of the English Language. (1989). New York: Portland House.

Wellar, B. (2001, June 15). 'Smart growth' can't be smart if it is predisposed to growth. The Ottawa Citizen. Retrieved from http://aix1.uottawa.ca/ wellarb/documents/Smart\%20Growth.pdf.

Wheeler, S. (2003). The evolution of urban form in Portland and Toronto: Implications for sustainability planning. Local Environment, 8(3), 317-336. 
Whitford, J. Environment Ltd. (2001). Building a sustainable city: The new city of Ottawa baseline report. Quality of life indicators. Ottawa: Jacques Whitford Environment Ltd.

World Commission on Environment and Development (WCED). (1987). Towards sustainable development. In G.H. Bruntland (Ed.), Our common future (pp. 43-66). Oxford: Oxford University Press.

Zeemering, E. (2009). What does sustainability mean to city officials? Urban Affairs Review, 45(2), 247-273. 


\section{Appendix A}

The 10 principles of Smart Growth (adapted from SGCN, 2007)

- Range of housing opportunities / choices

- Walkable neighbourhood

- Community / stakeholder collaboration

- Distinctive, attractive communities with a strong sense of place

- Predictable, fair, and cost-effective development decisions

- Mixed land uses

- Preserve open space, farmland, natural beauty, critical environmental areas

- Variety of transportation choices

- Strengthen and direct development toward existing communities

- Use compact building design 


\section{Appendix B}

\section{Discursive constructions of Barrhaven as the antithesis of sustainability}

\begin{tabular}{|c|c|}
\hline Source & Quotation \\
\hline \multirow{7}{*}{ Interviews } & $\begin{array}{l}\text { It's depressing to think that ... you can't just say 'Oh, we screwed up there; } \\
\text { let's go backwards a bit, let's just pull it all back in. You know, it's like if } \\
\text { you buy a suit and it's too big, well yah, you can have it re-tailored; you } \\
\text { can't do that with ... with the Barrhavens of this world, unfortunately }\end{array}$ \\
\hline & $\begin{array}{l}\text {... they're spending fifty million like that, in the drop of a hat, to extend a } \\
\text { three lane road in, say, Barrhaven, in order to encourage urban ... what, not } \\
\text { to encourage ... they wouldn't ever say that ... to encourage urban sprawl, } \\
\text { but in fact that's what it's doing. }\end{array}$ \\
\hline & $\begin{array}{l}\ldots \text { the communities that are around Ottawa, that are in that are in that kind } \\
\text { of ... rural ribbon ... they have a common interest, and we don't ... it's not } \\
\text { that we hate them ... we have very ... city folk, city people have a very } \\
\text { different interest. Now the ones in between: Barrhaven I don't know. } \\
\text { That's a no man's land for as far as I'm concerned }\end{array}$ \\
\hline & $\begin{array}{l}\text { Well, } \ldots \text { and it is water under the bridge now, } \ldots \text { there's additional } \\
\text { housing, and there's a big new school out in Barrhaven (laughs) that we ... } \\
\text { that developer funded }\end{array}$ \\
\hline & $\begin{array}{l}\ldots \text { there was whole principle involved ... of a school that was seventy years } \\
\text { old that had been paid for by taxpayers being sold to a developer; and I } \\
\text { know the school board has to build schools and gymnasiums and theatres } \\
\text { and everything, out in Barrhaven; but ... I just felt it was morally wrong } \\
\text { what they did }\end{array}$ \\
\hline & $\begin{array}{l}\ldots \text { the idea was to build } \ldots \text { instead of creating a city around cars and } \\
\text { freeways, the way we did in Orleans and Kanata, and in Barrhaven, to have } \\
\text { one little section of the city to grow up around electric light rail service }\end{array}$ \\
\hline & $\begin{array}{l}\ldots \text { there was a rural Kanata versus urban Kanata kind of thing (laughs). So, } \\
\text { but ... so they had to address that question of the insustainability of the } \\
\text { monoculture a lot earlier than the City has had to do that, now that we've } \\
\text { had kind of a ... you know, where the downtown core has, kind of ... it is a } \\
\text { hipster kind of place to be, again, but, what happens to all those people, } \\
\text { they live out in Barrhaven now ... }\end{array}$ \\
\hline
\end{tabular}




\begin{tabular}{|l|l|}
\hline \multirow{1}{*}{ Newspaper } & $\begin{array}{l}\text {... there's going to be probably fifty million dollars to build the Strandherd } \\
\text { Bridge to connect, you know, Riverside South to Barrhaven and that. Is } \\
\text { that sustainable? If it is, pay for it with your own taxes. }\end{array}$ \\
\hline & $\begin{array}{l}\text { Of particular poignancy is the contrast between the smallness of many Old } \\
\text { neighbourhood and maintains green spaces along the frontage of properties } \\
\text { as they are redeveloped. He described how development in other parts of } \\
\text { loaded with suburban accoutrements. It's a case of Barrhaven meeting Old } \\
\text { Ottawa South (Cook. 2008, June 23). } \\
\text { the city has turned streetscapes into asphalt jungles, where the prominence } \\
\text { street full of garages, they're a dime a dozen,' (Pearson, 2010, April 13). }\end{array}$ \\
\hline
\end{tabular}




\section{Appendix C}

Guiding principles of the 1991 City of Ottawa Official Plan (Ottawa, 1991a)

- Conserve and enhance the resource base

- Manage the natural setting

- Commit to efficient land use patterns

- Promote a strong and diverse economy

- Manage growth

- Facilitate neighbourhoods as building blocks

- Increase non-auto transportation

- Provide adequate shelter with a variety of housing choice

- Provide a safe environment

- Promote the city as a people place

- $\quad$ Provide barrier free access

- Protect heritage resources

- Apply urban design

- Manage change

- Commitment to public involvement 